$$
\text { العلاقات الإيرانية- السعودية 1979-2001 دراسة سياسية }
$$

هممد سالم احمد الكهاز

$$
\text { مستخلص البهث : }
$$

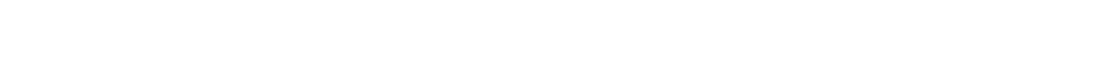

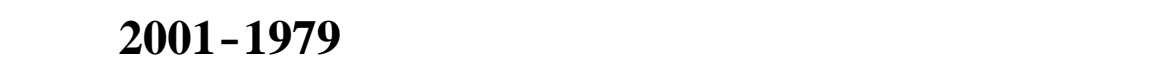

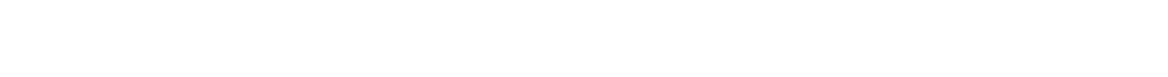

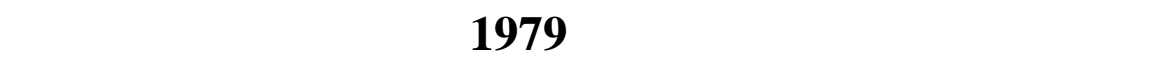

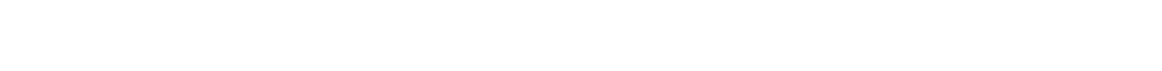

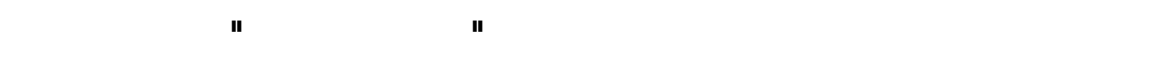

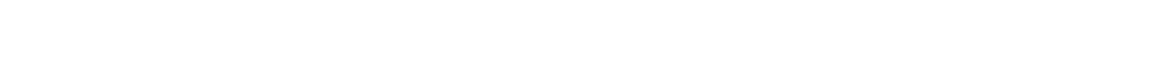

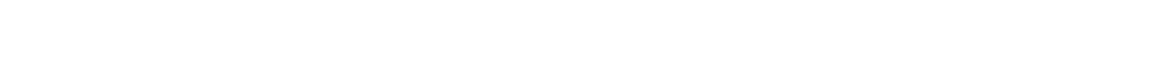

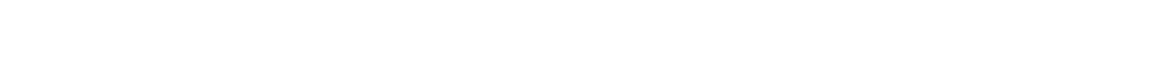

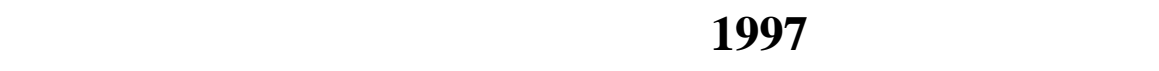

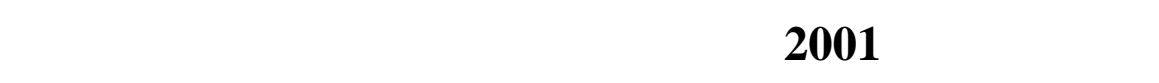
والتوتر الني كلنقائماً بشكل مفاوت بين البلدين. 


\section{العلاقات الإيرانية - السعودية 1979-2001 \\ دراسة اسياسية - اليسية}

\section{* همد سالم احمد الكواز}

المقدهة :

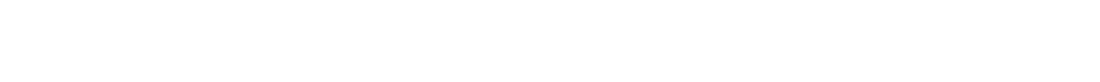

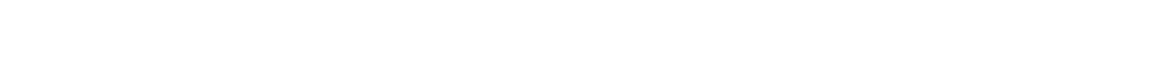

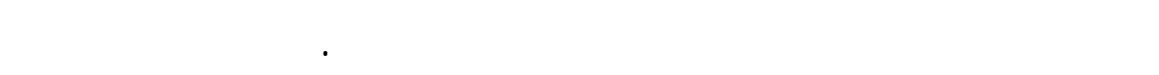

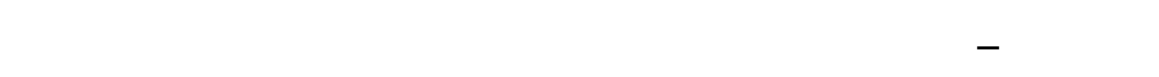

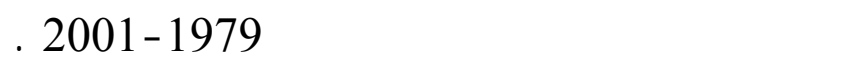

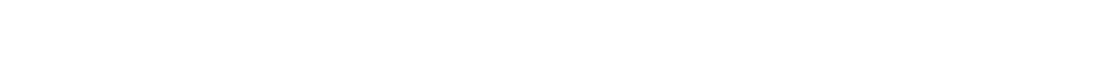

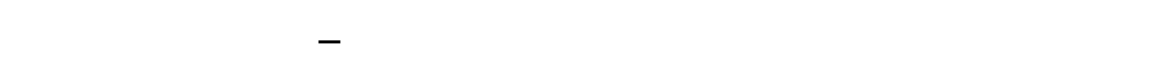

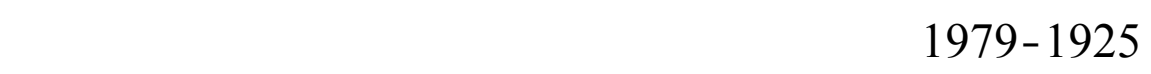

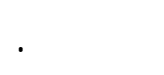

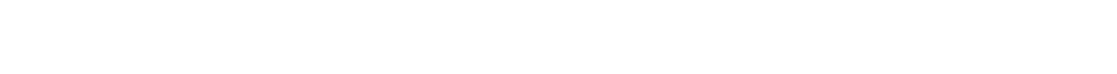

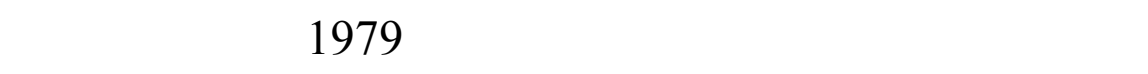

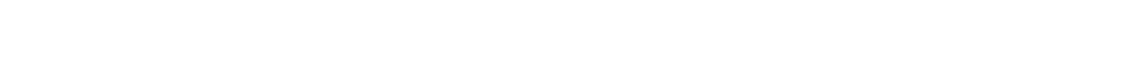

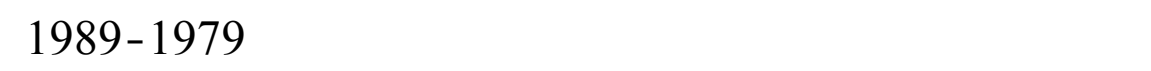

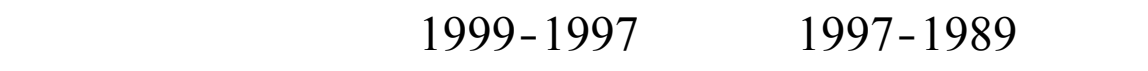

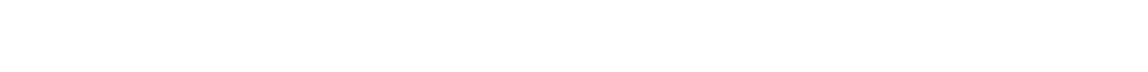

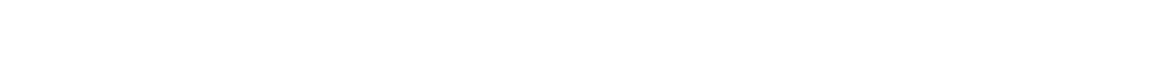
والاقتصادية. *مدوس طساعد/مركز الررلسلت الإليمية/جامعة الموطل. 
الما المحور الثالث، فأنه جاء ليعزز التع اون والق ـة ف في علاق لـ الت

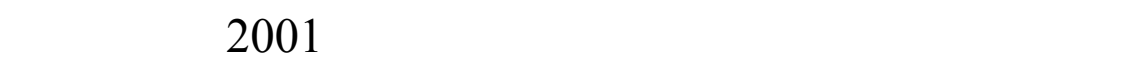

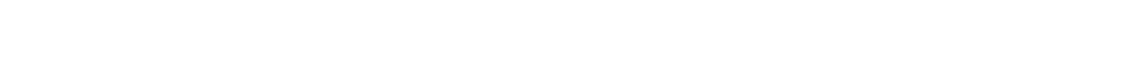
الصعينين الاقليهي والدولي.

\section{رؤبةفي الجنور التأربخية الملافلت الميلسية

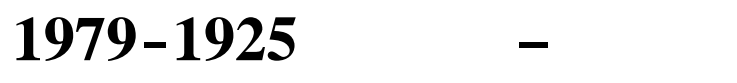

التسمت العلاقلت الايرانية العربية بصورة علمة والعلاقلت الايرانية

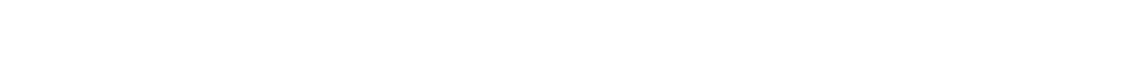

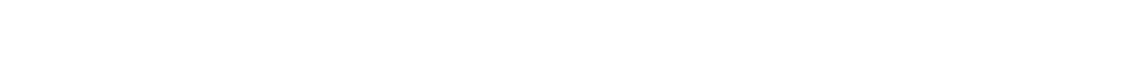

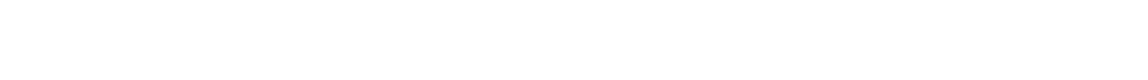

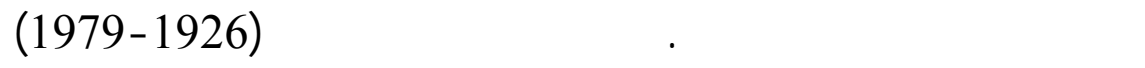

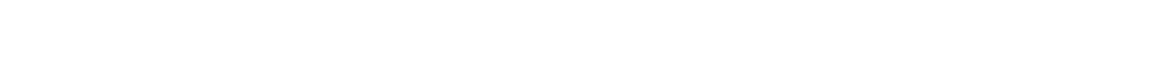

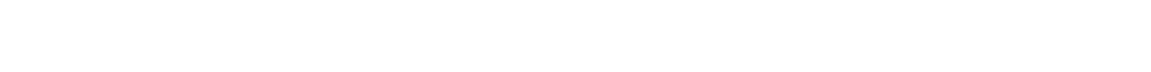

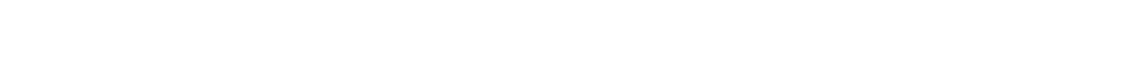

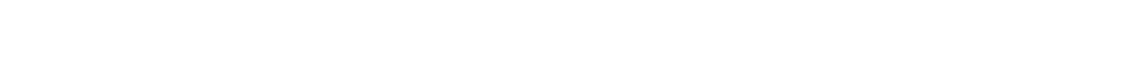

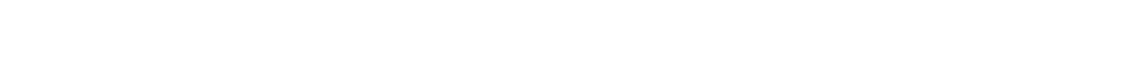

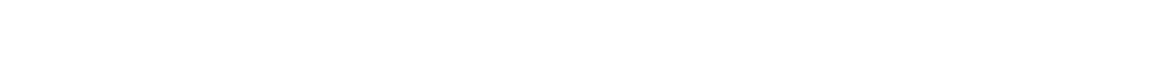

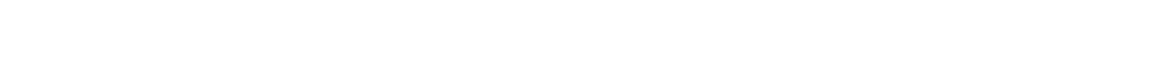

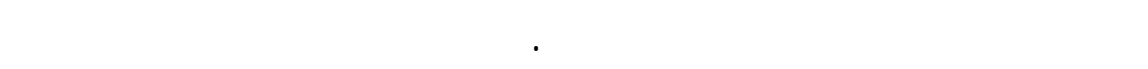

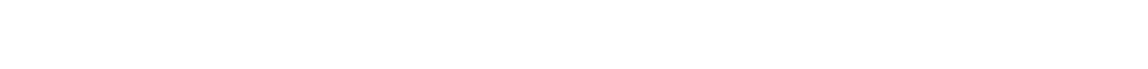

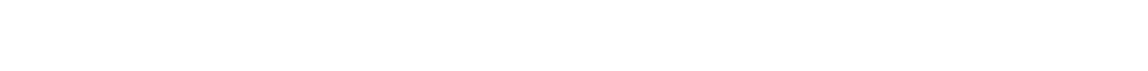




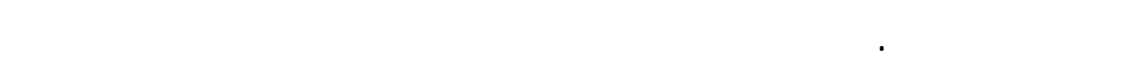

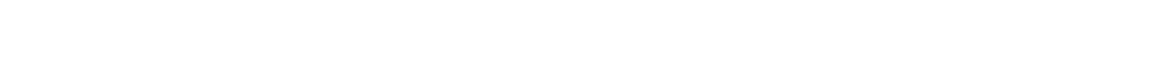

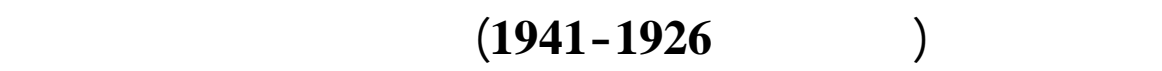

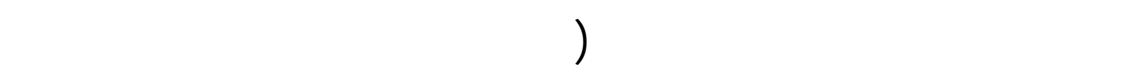

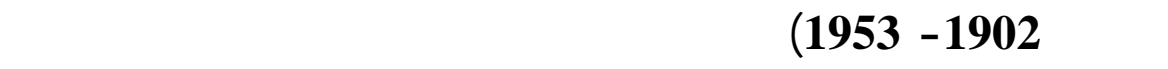

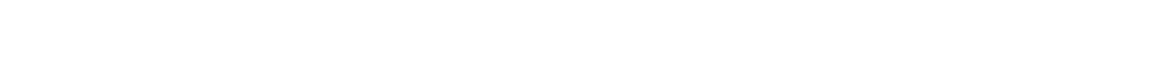

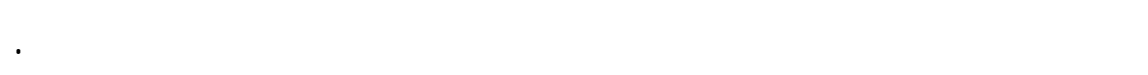

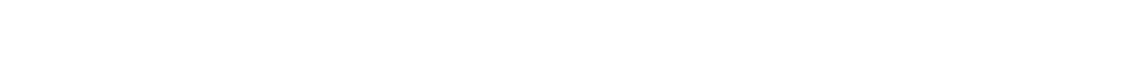

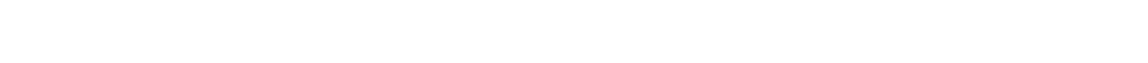

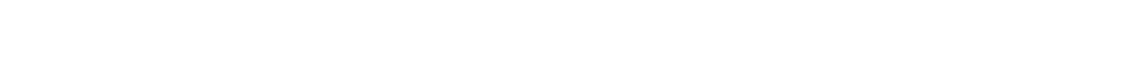

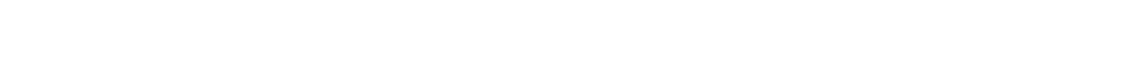
الدينية في ايران.

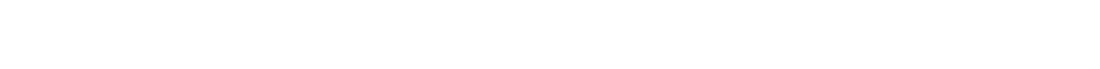

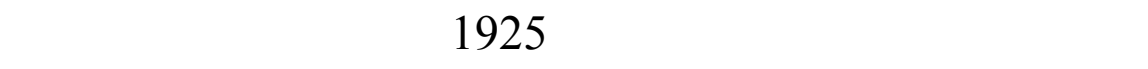
بمساعي وسطلة بين الملك عبد العزيز وبين علي بن المسين ملك الحبن الحجاز

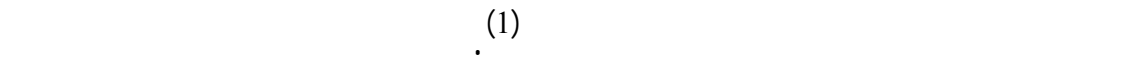

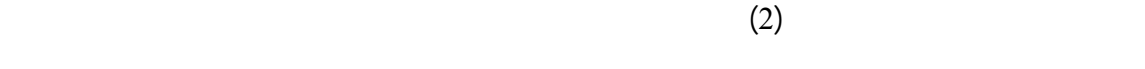

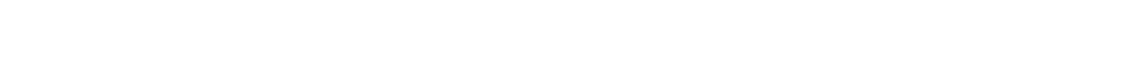

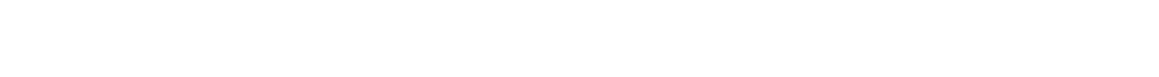

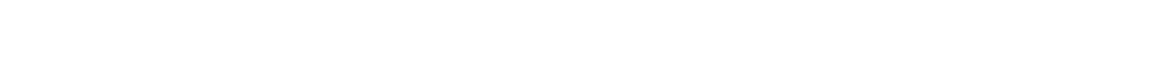

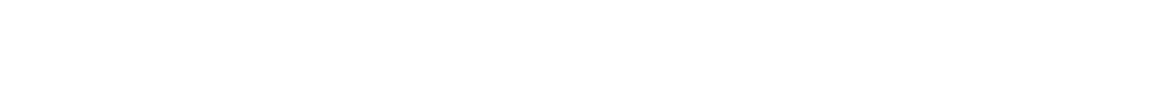

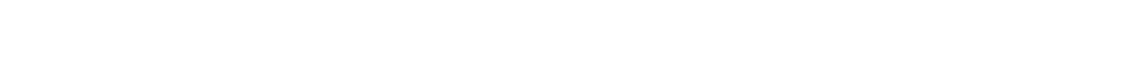

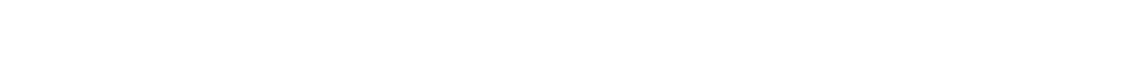




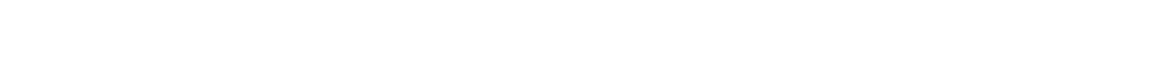

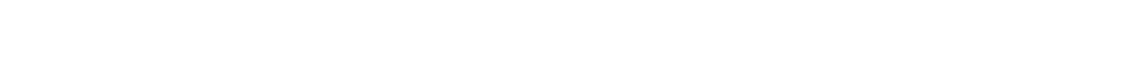

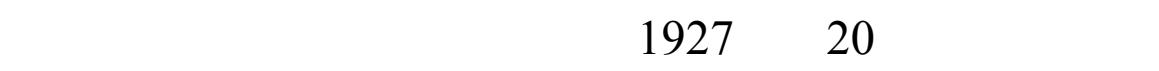

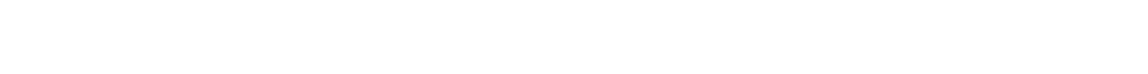

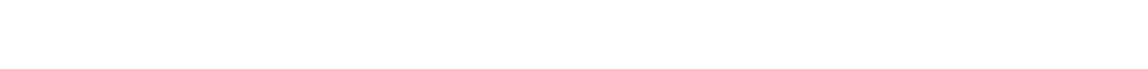

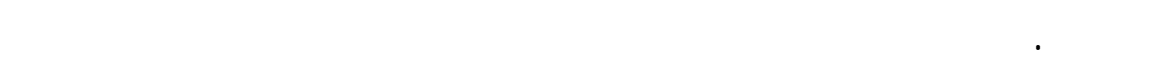

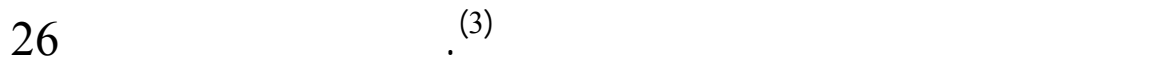

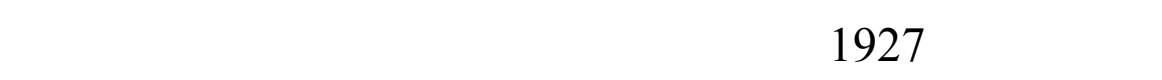
البحرين (4). ففي الواقع ان الفرس الايرانين يظرون الم واله الخلبج العربي بأعتب اره

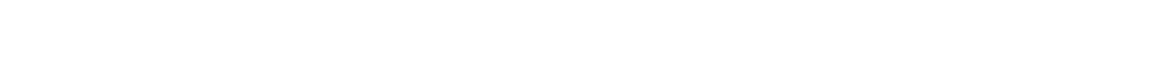

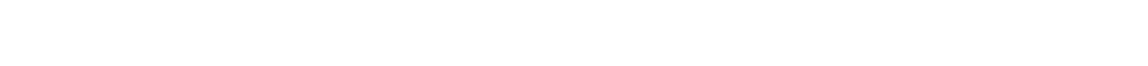

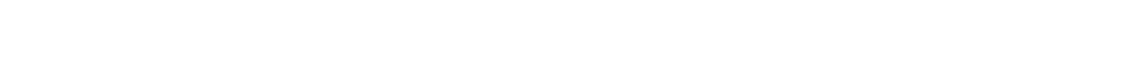

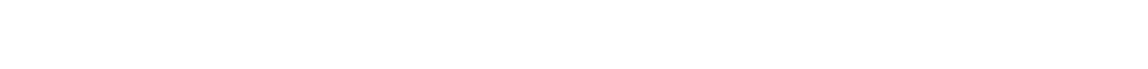

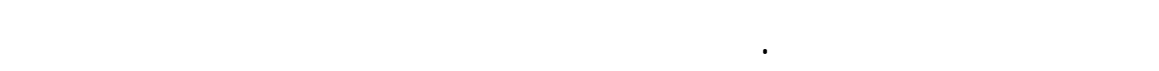

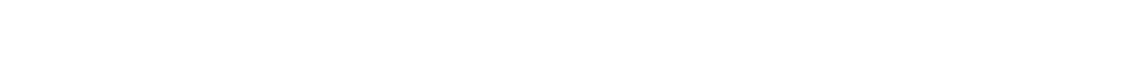

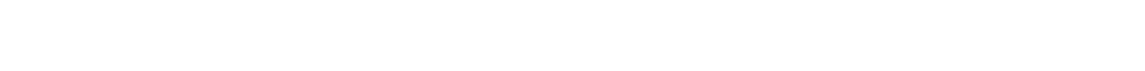
عالمياً بصورة لكبر.

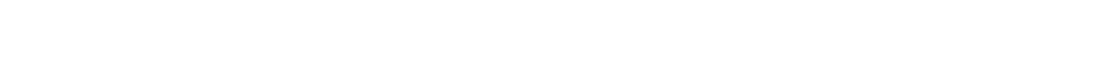

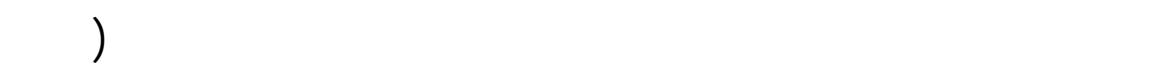

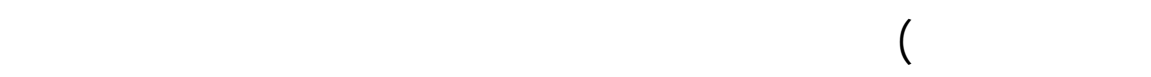

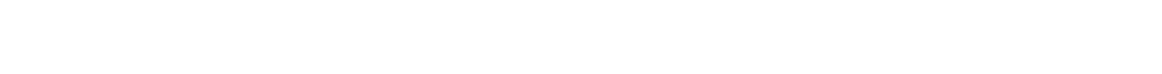

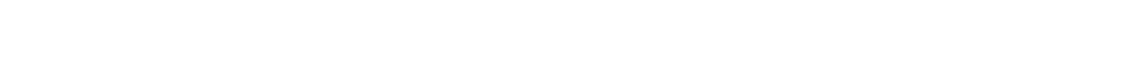




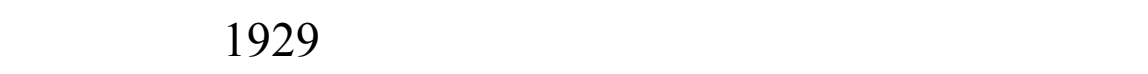

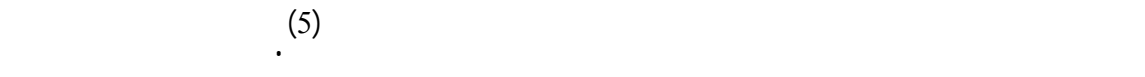

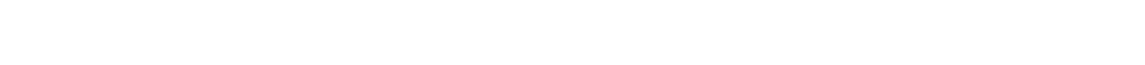

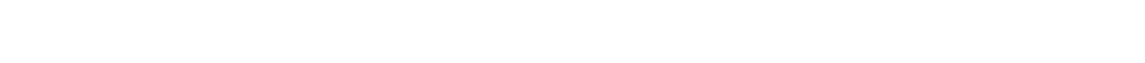

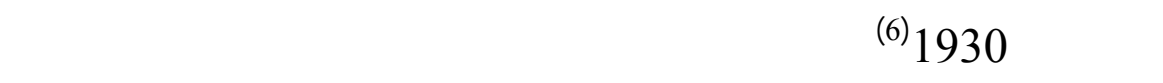
ونائبه الامير فيصل اله طهران علم 1932 لتعزيز العلاقلت ولستمرارها

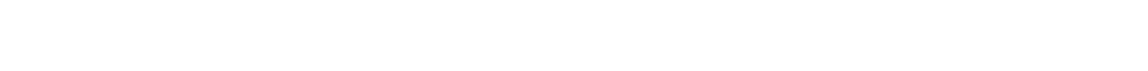

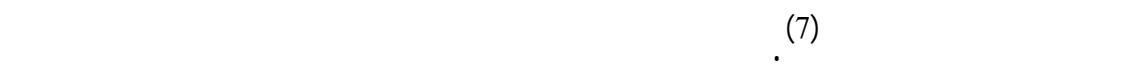

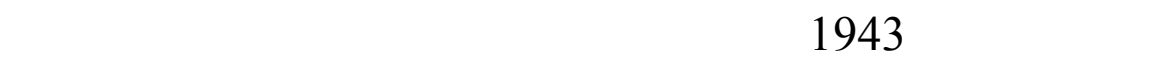
اله قطع تلك العلاقلت اللسيلسية بين الحكومتين خ ـاله الفت ـرة 1944 ${ }^{(8)} 1946$

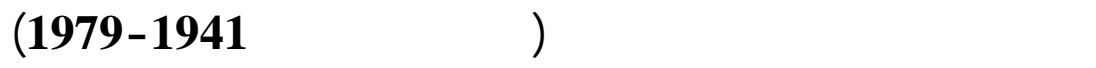

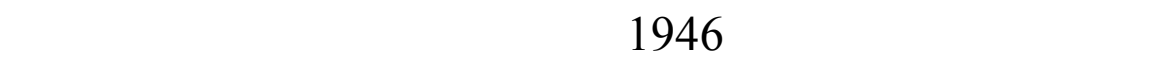

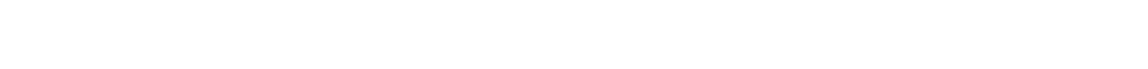

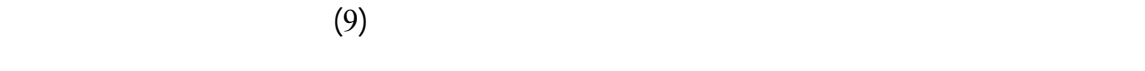

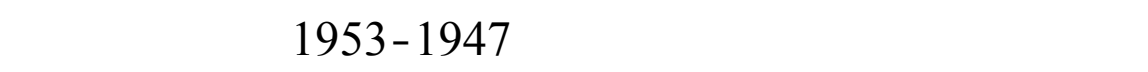

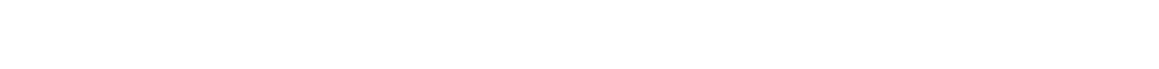

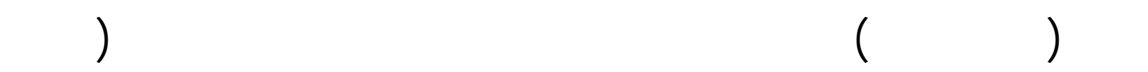

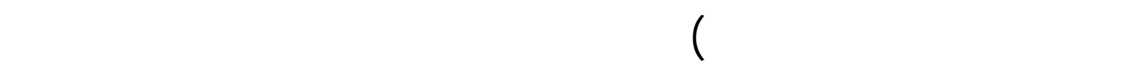

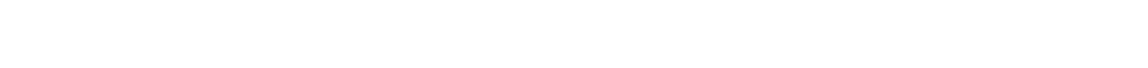

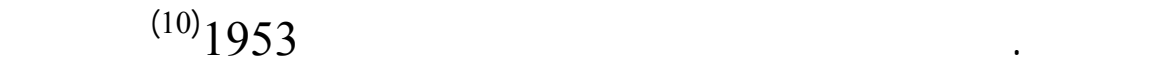

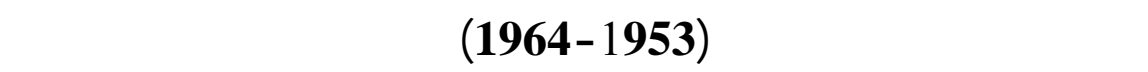

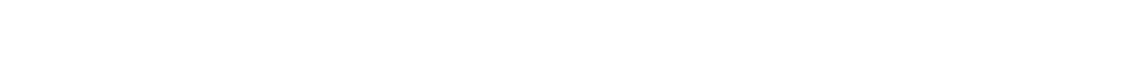




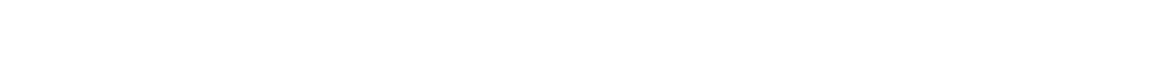

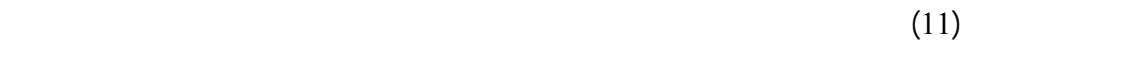

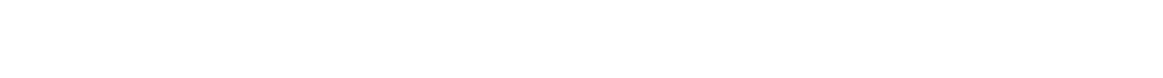

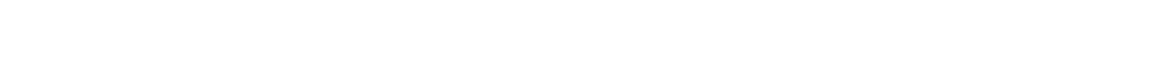

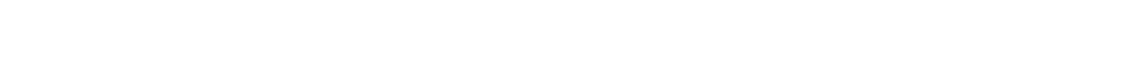

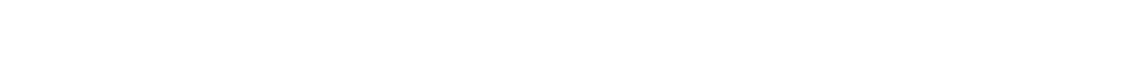

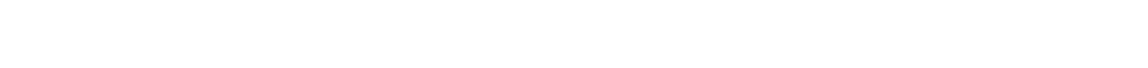

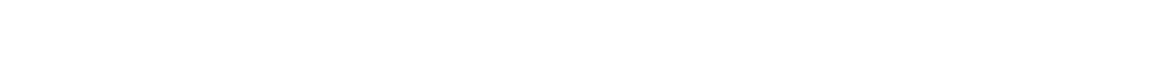

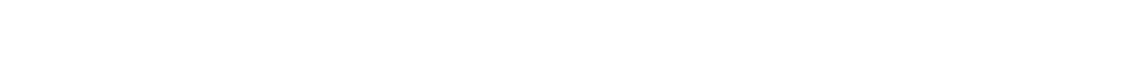

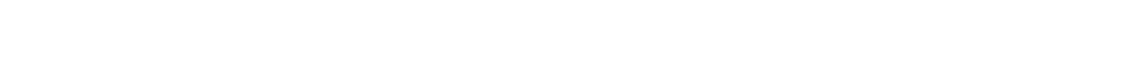
البريمي في 26 تشرين الاول 1955 (12).

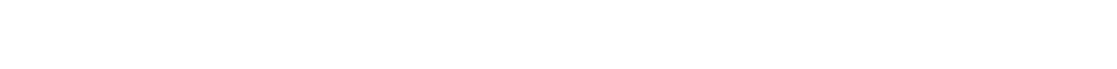

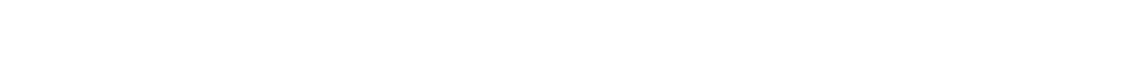

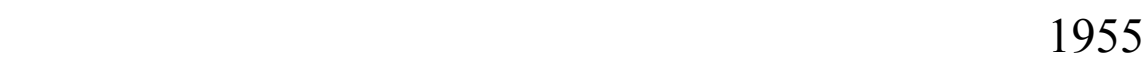

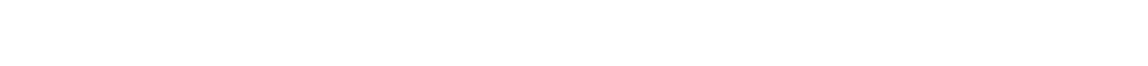

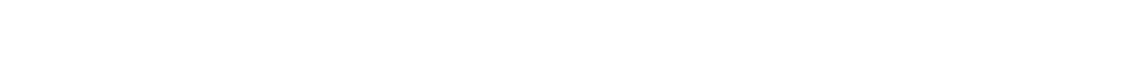

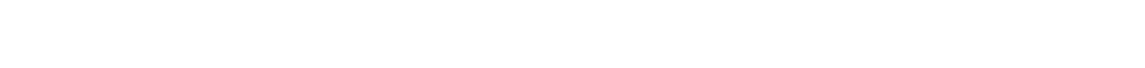

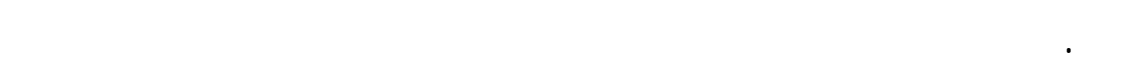
. $^{(13)} 1955$

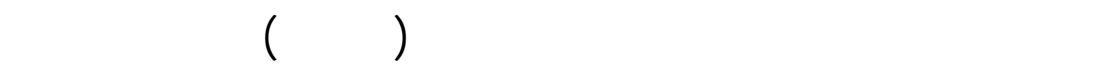

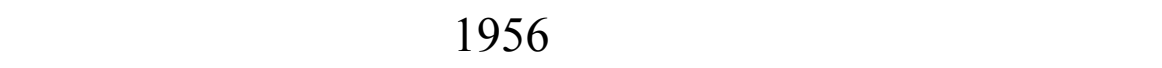

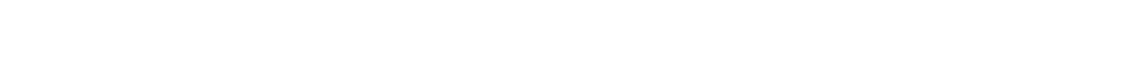

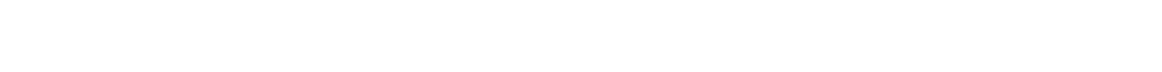

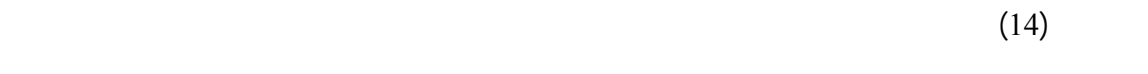




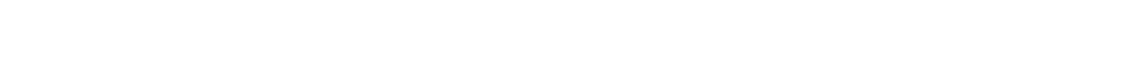

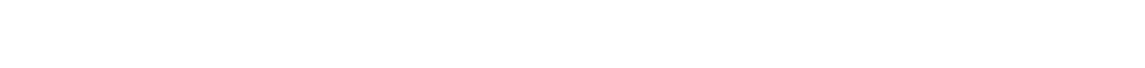

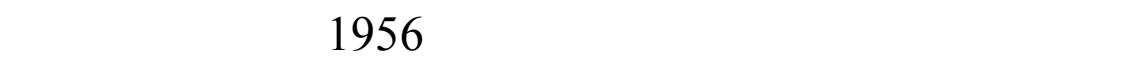

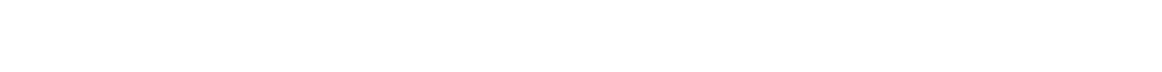

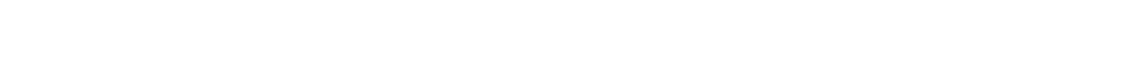

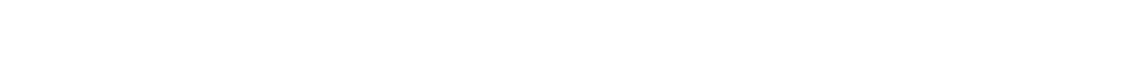

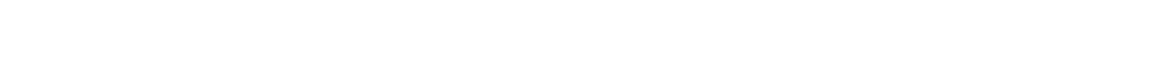

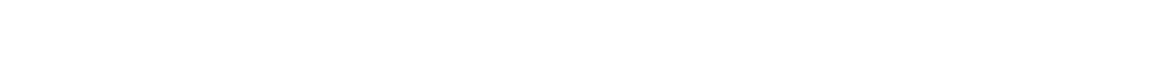

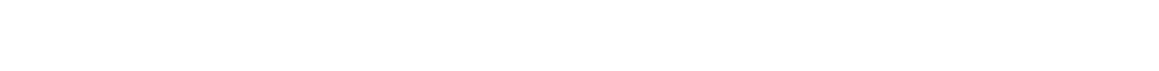

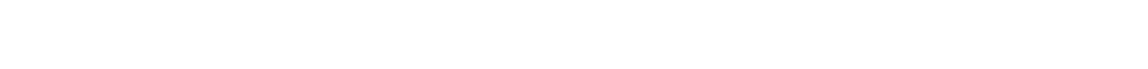

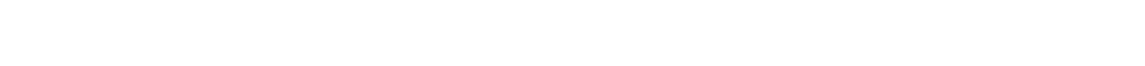

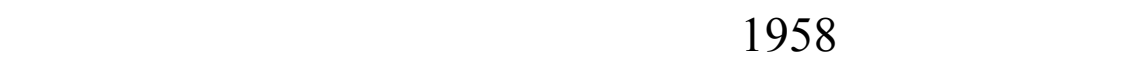

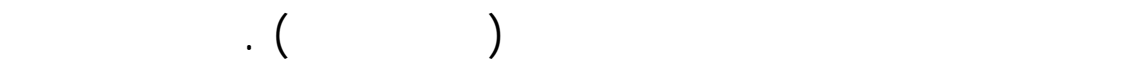

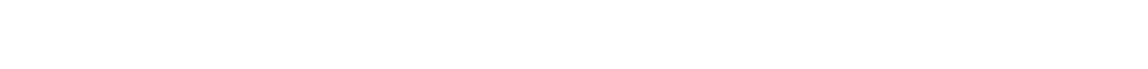

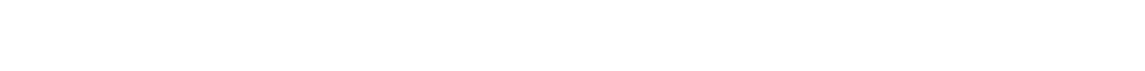

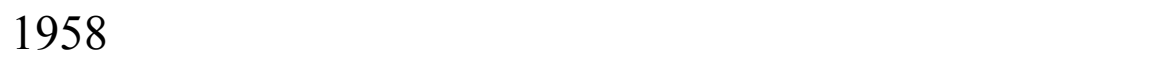
ولستبداله بظظلم ثوري جمهوري أملنين ان يكون هذا الظالم الاخير لكث ـر اهتملماً قِضايا العالم العربي (15). وبتأكيد ايران على الاعترف بلُسررائل باعتبارها دولة في علم 1960،

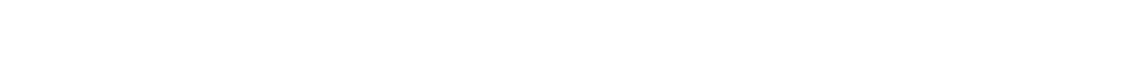

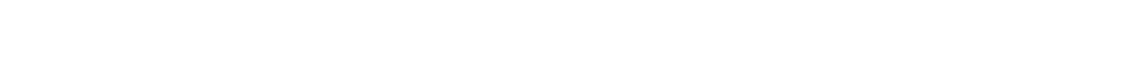

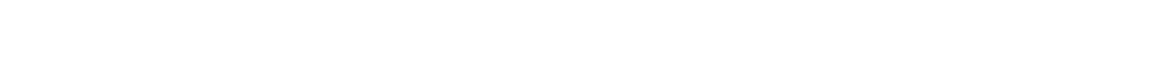

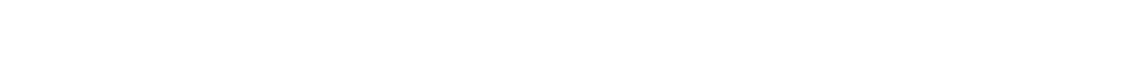


التتهت تلك القضية حق لستعادت المملكة رواططها الاعتياية مع لي -ران

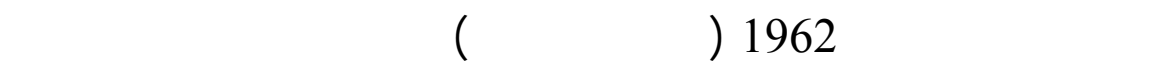

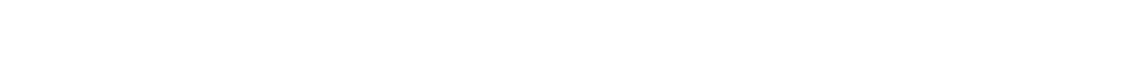

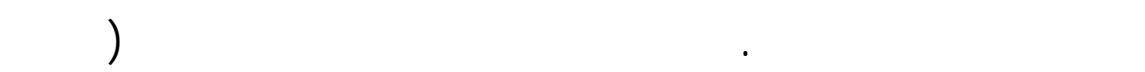

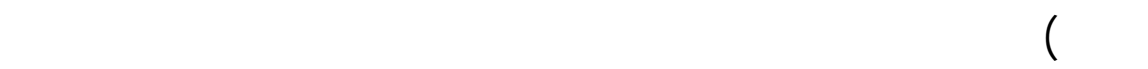

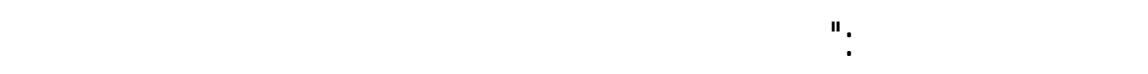

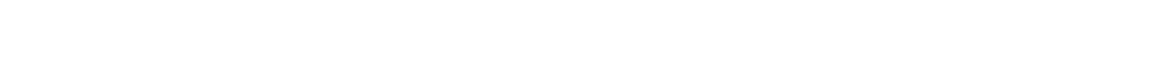

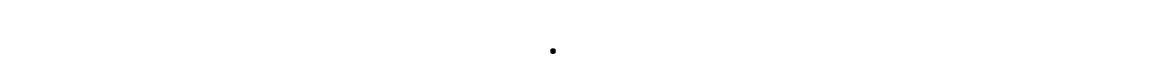

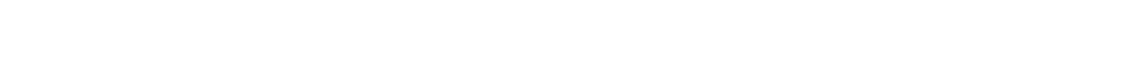

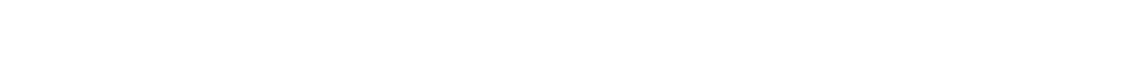

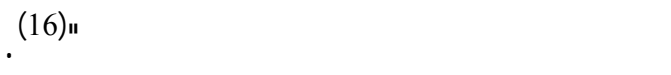

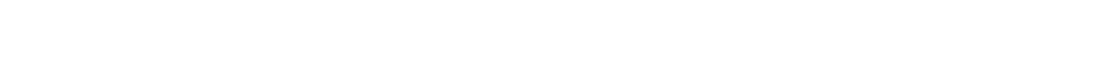

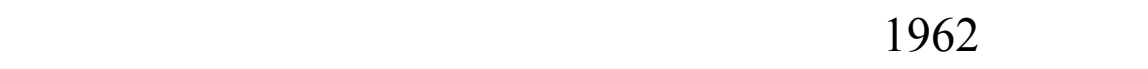

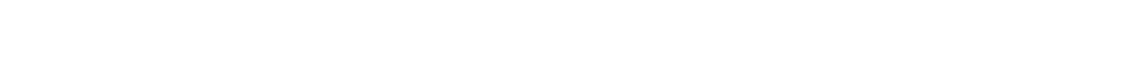

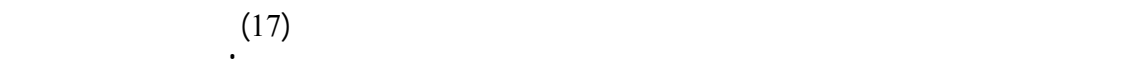

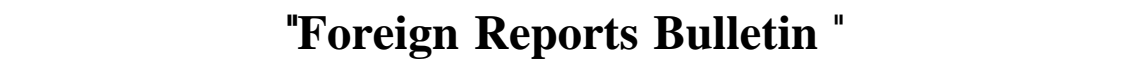

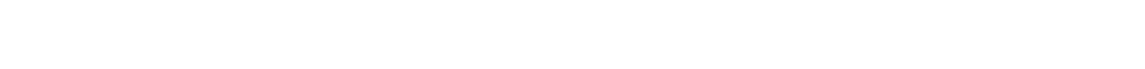

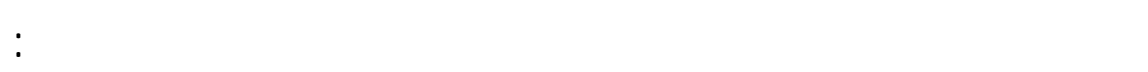

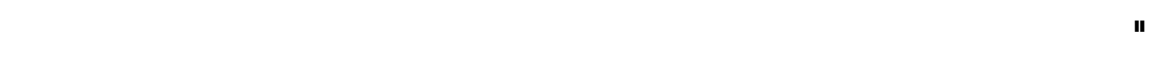
السملرة عل هملشبه الجزبرة العربية" (18).

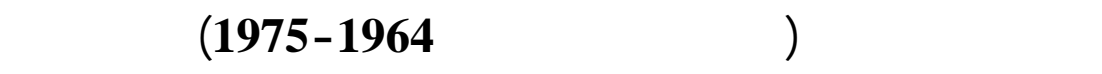

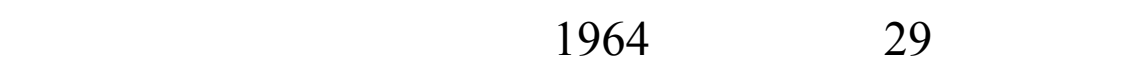

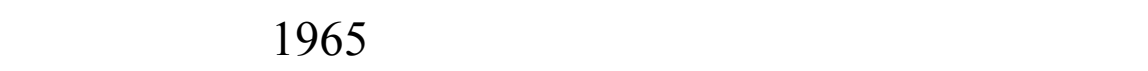




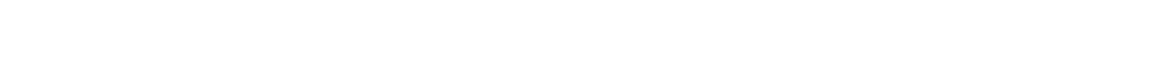

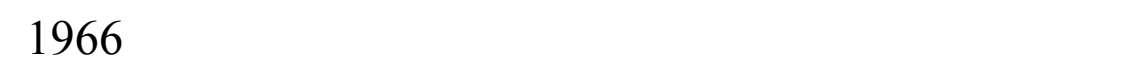

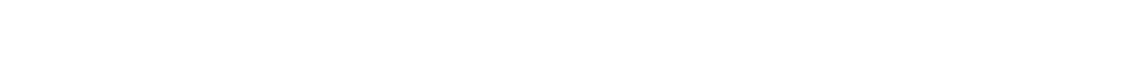

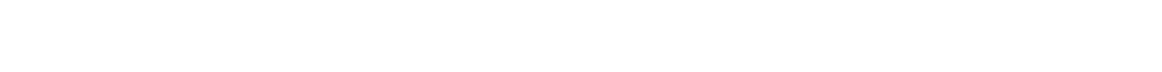

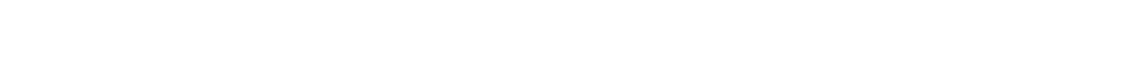
البلدين (19) .

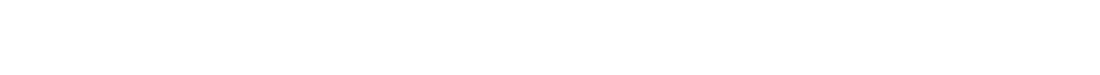

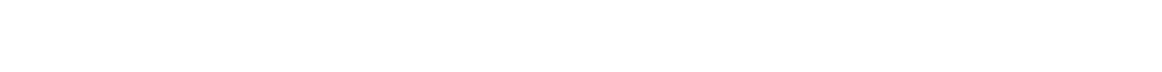

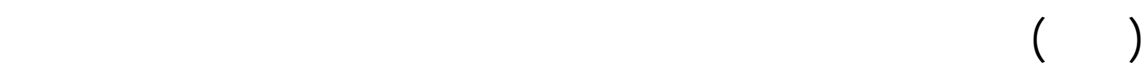

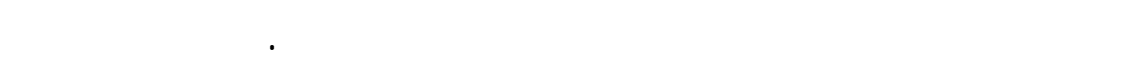

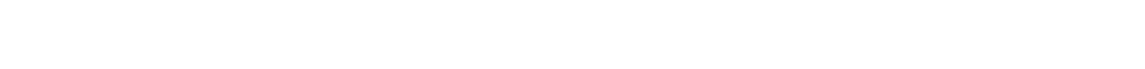

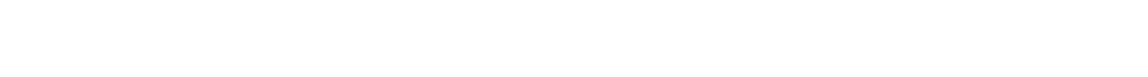

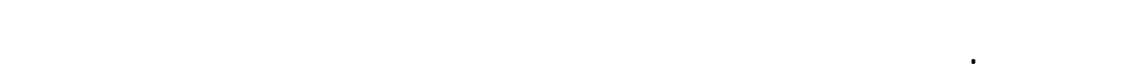

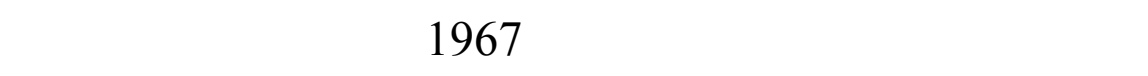

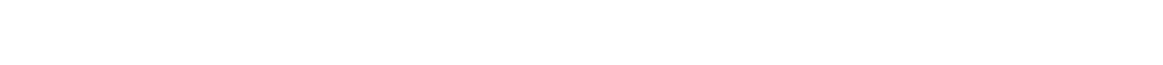

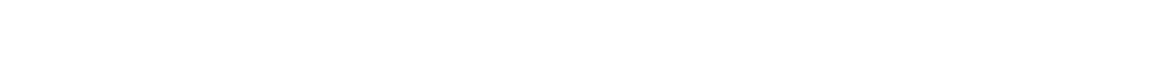

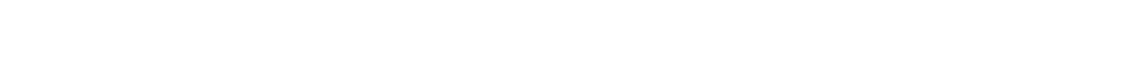

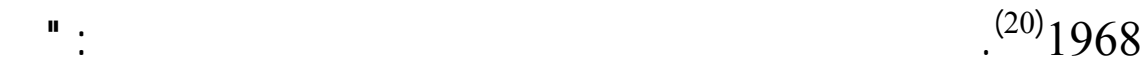

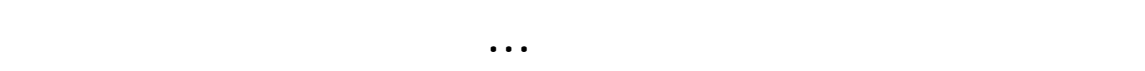

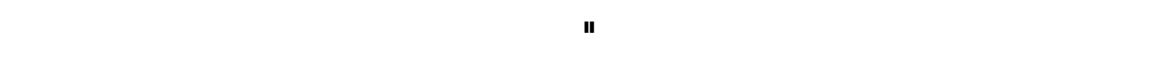

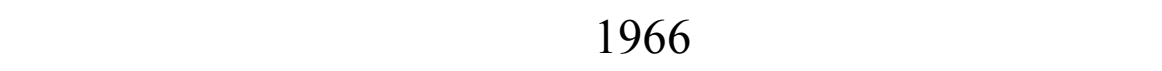

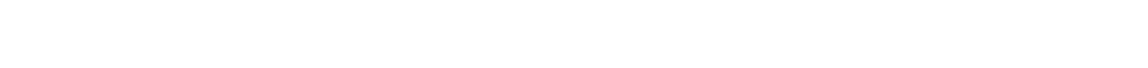
خلافت الشه مع العراق (21). - ال 


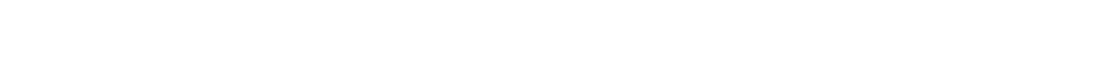

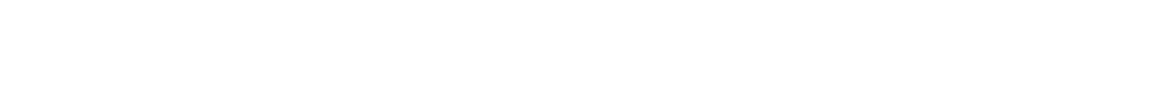

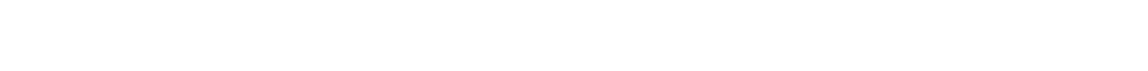

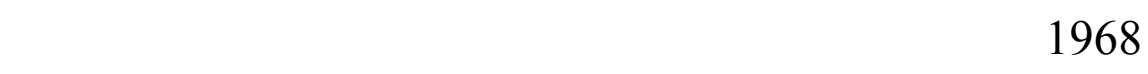

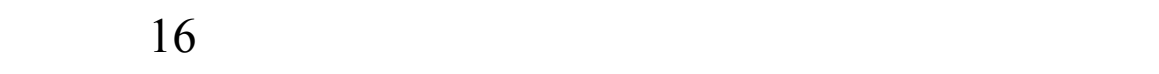

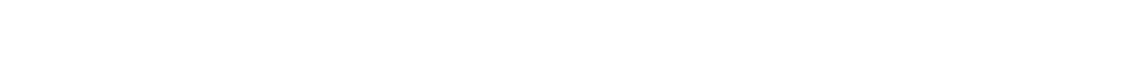

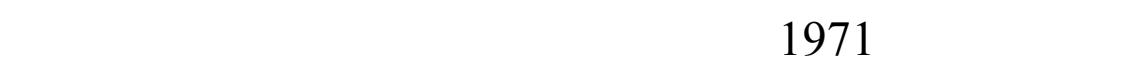

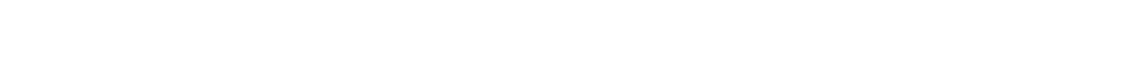

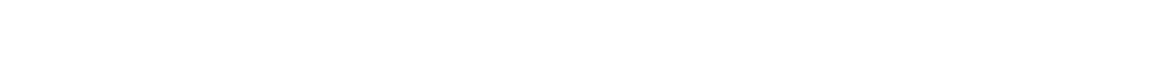

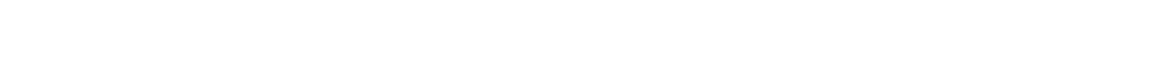

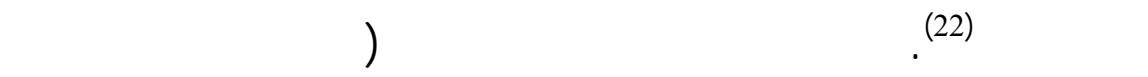

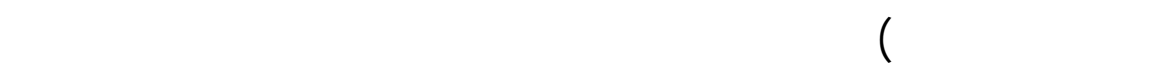

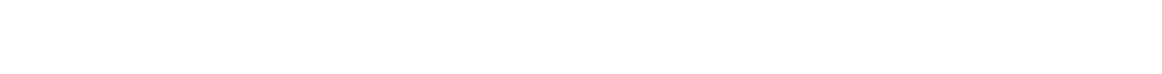

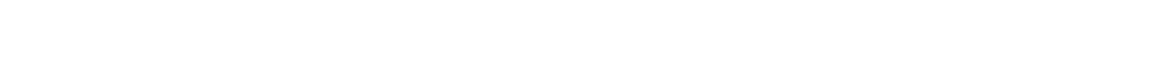

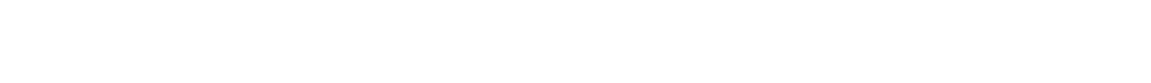

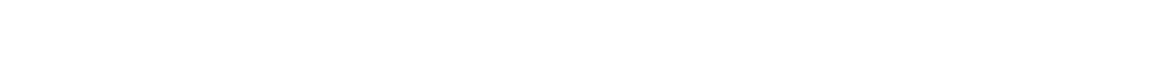

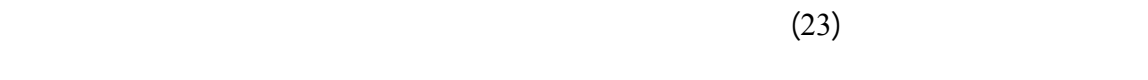

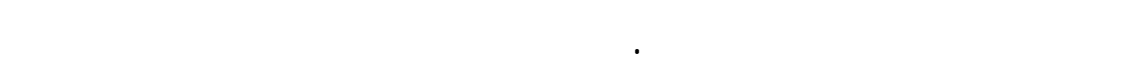

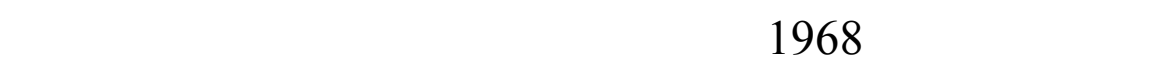

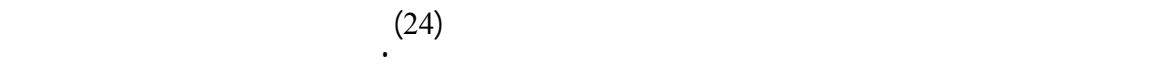
بدعوة للشه لزيارة الرياض في الوقت ذالته، فق القاء في الموعد المحدد المداد

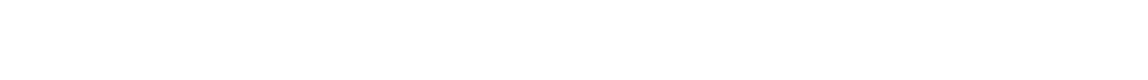

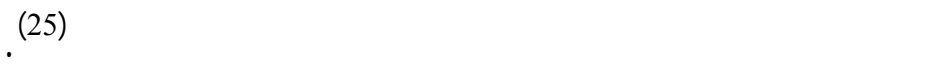




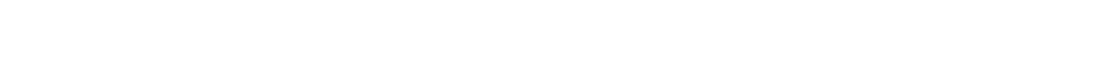

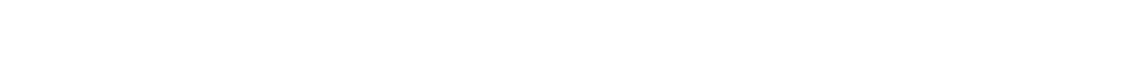

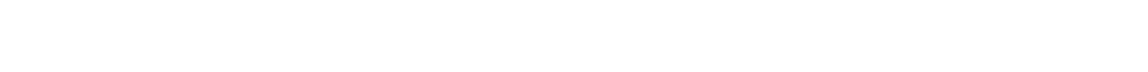

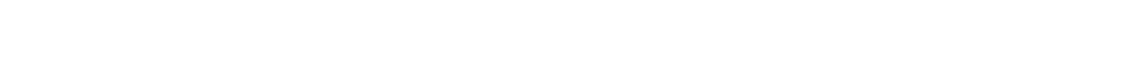

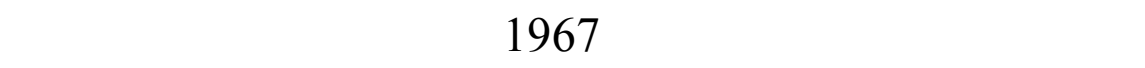

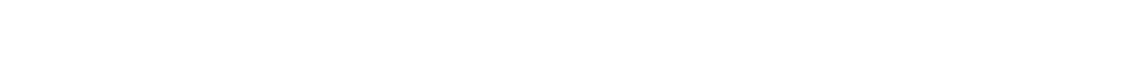

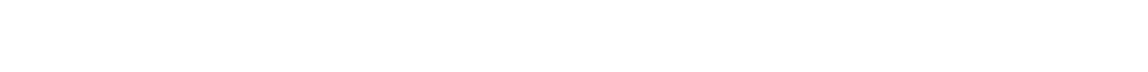

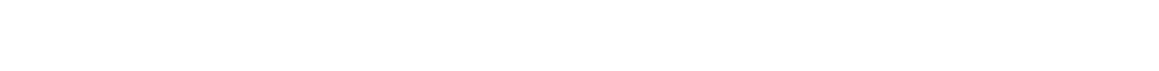

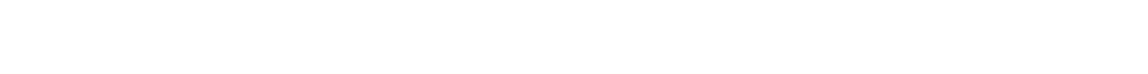

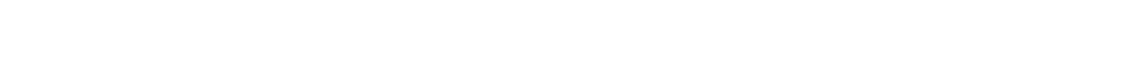

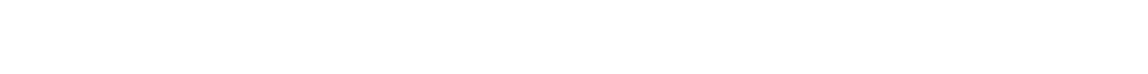

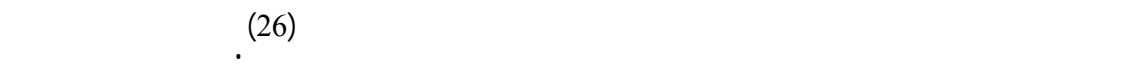

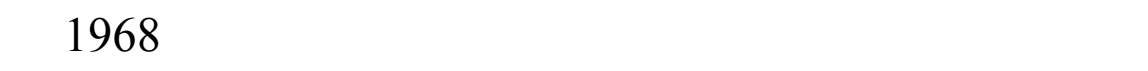

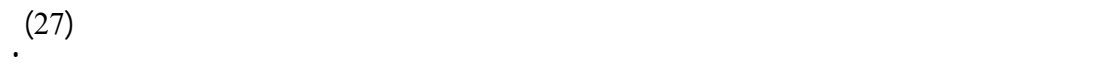

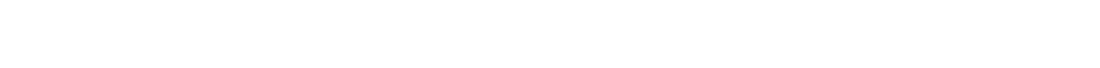

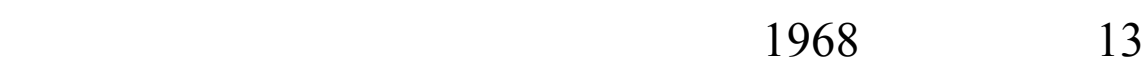

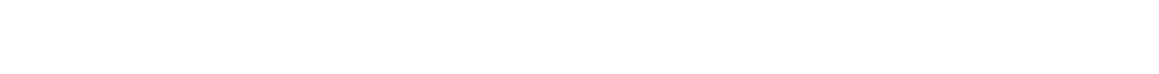

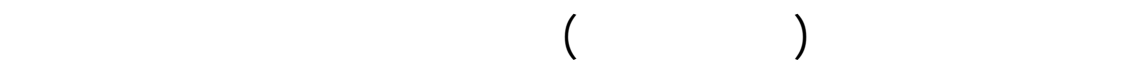

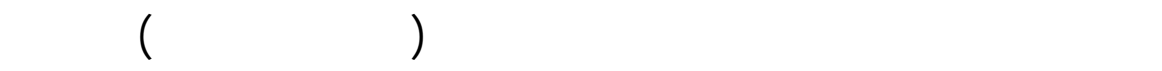

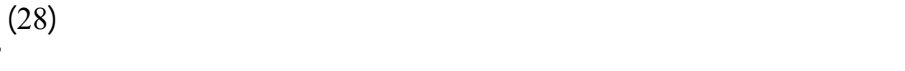

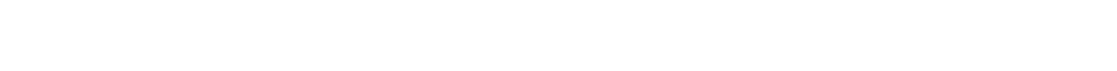

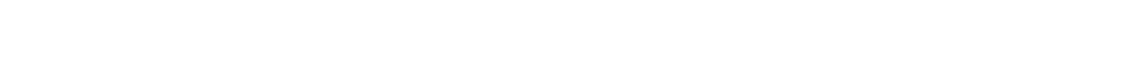

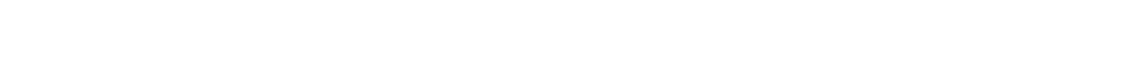

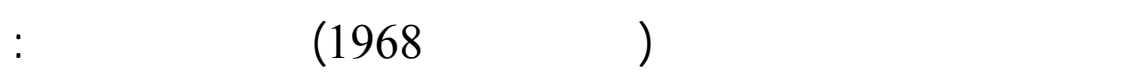


"... لن تخلي ليرلن عن طالبتها بالجرين قد يهف النخلي عنشدميء

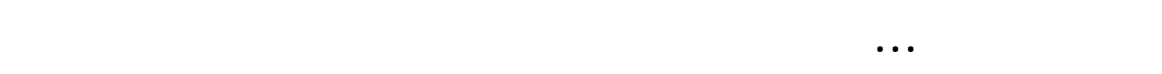

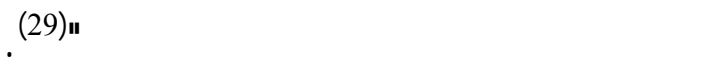

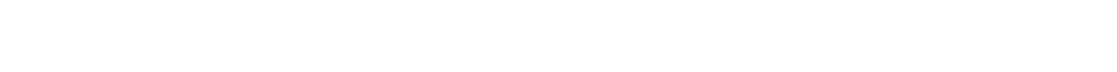

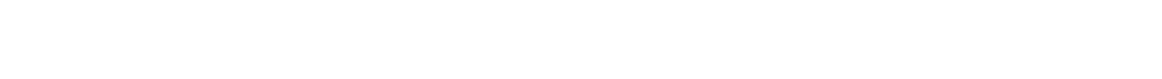

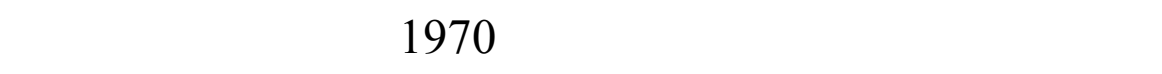

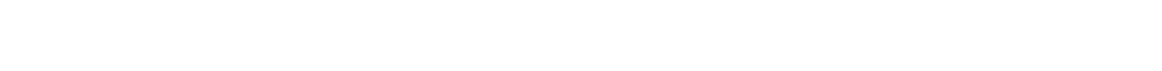

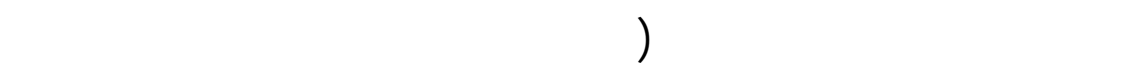

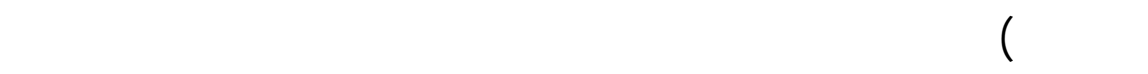

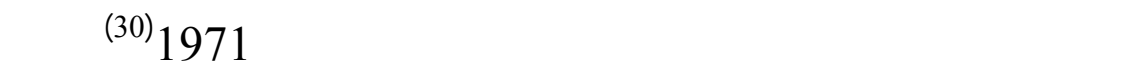

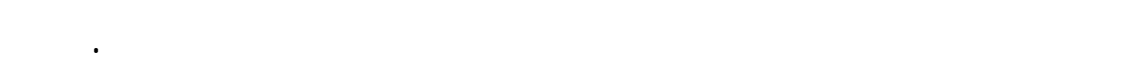

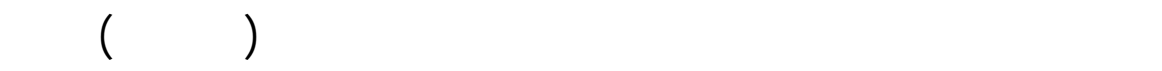

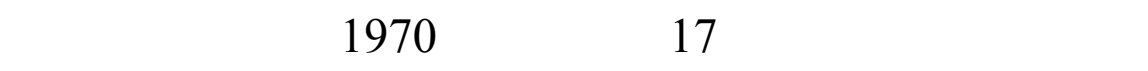

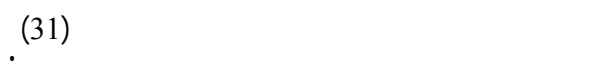

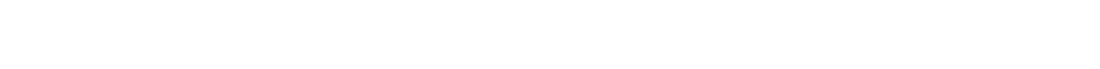

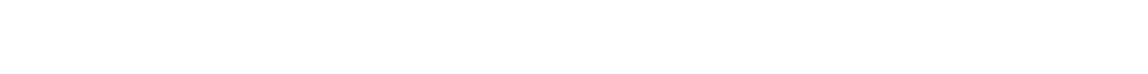

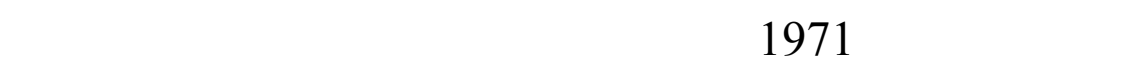

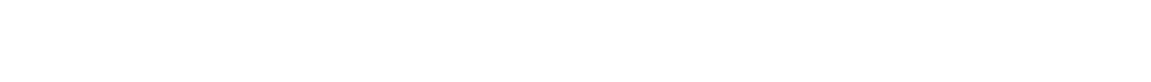

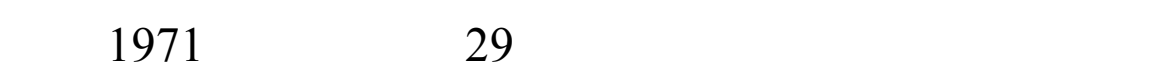

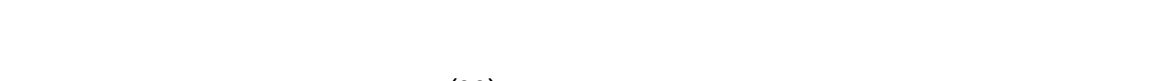

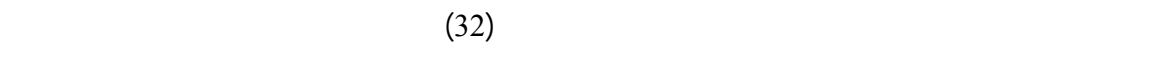

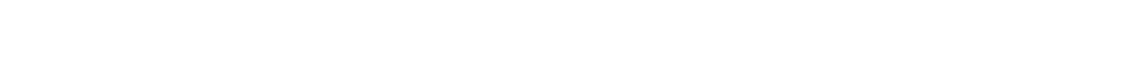

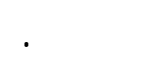


خلال الفترة 1973 -1977 تبالل الطرفان زيارات عدية وخاصة بعد

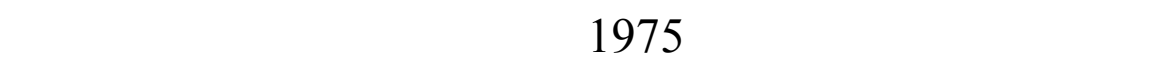

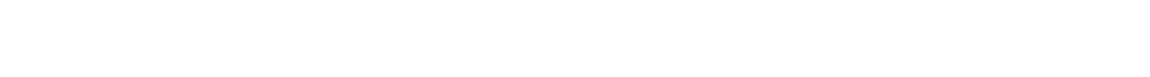

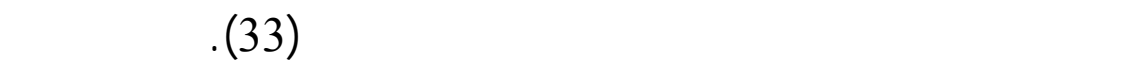

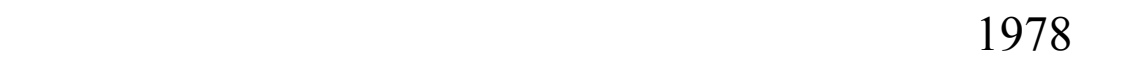

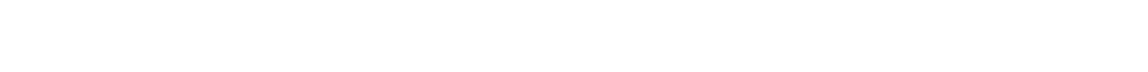

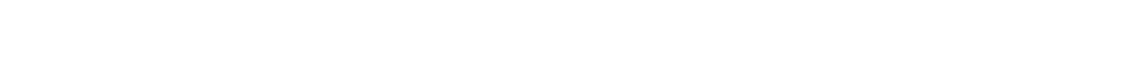

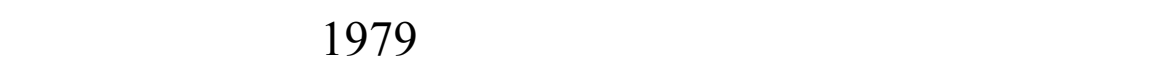

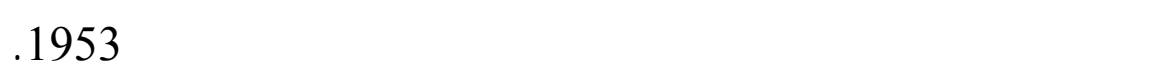

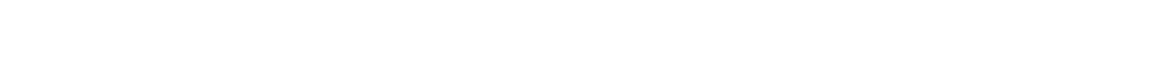

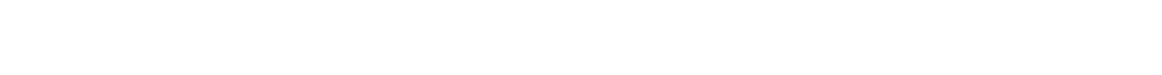

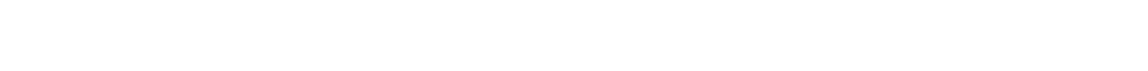
وهذا ماسنبينه بالفصل. و ولية.

\section{تطور العلاقات السياسية الإيرانية السعودية}

\section{$1999-1979$}

شهدت العلاقلت الايرلنية للسعودية مذ ـذ الذ ـدلاع الذ -ورة الإسد ـلامية

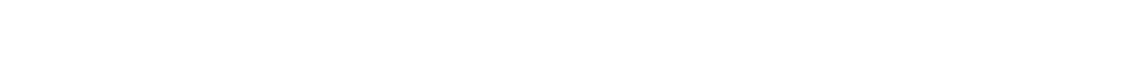

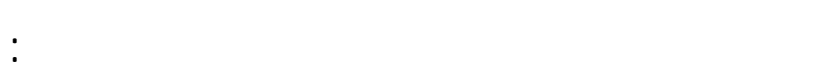


- المرحلة الاولى 1979-1989: كلن من المتوقع ان ترتاح المملكة العربية للسعودية ، ولمارات الخلبج

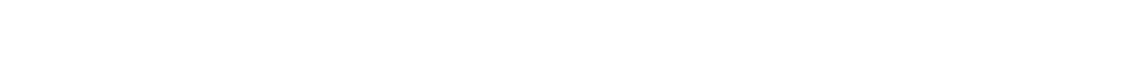

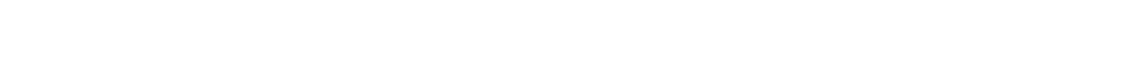

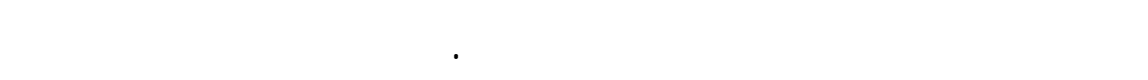

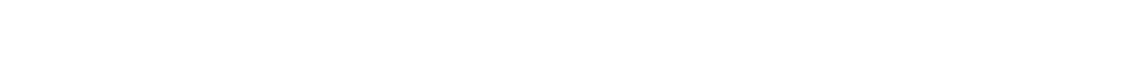

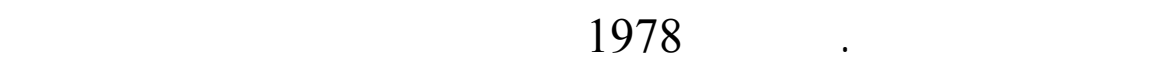

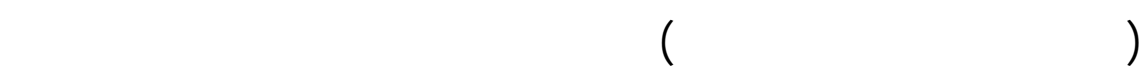

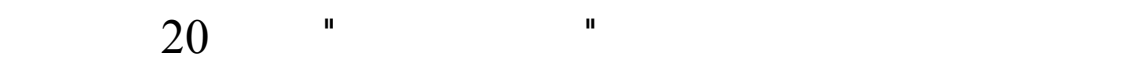

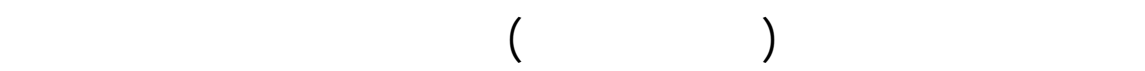

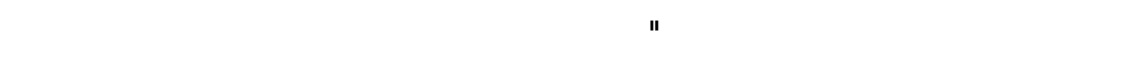

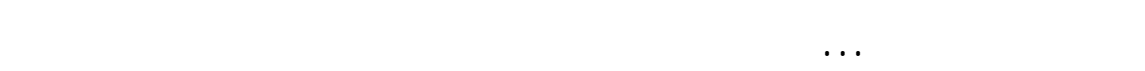

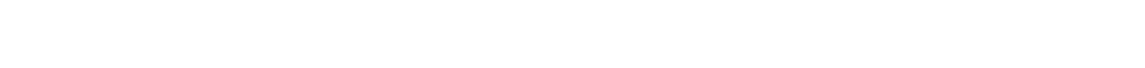

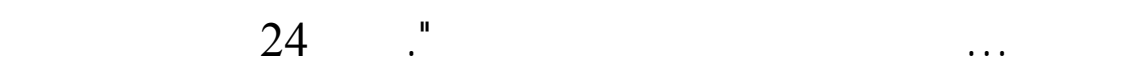

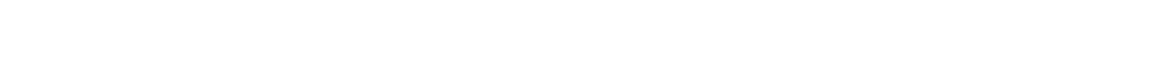

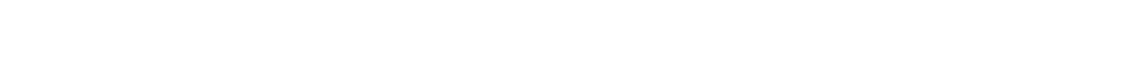

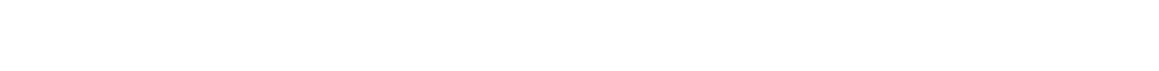

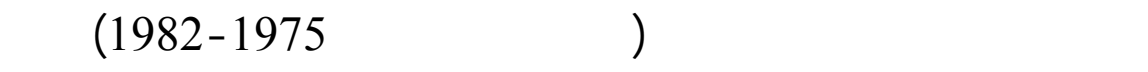

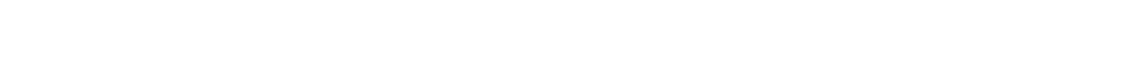
الازمة (34).

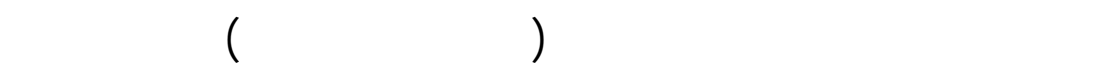

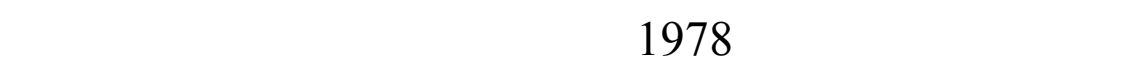

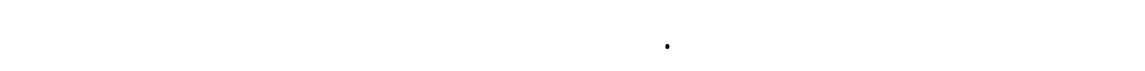


اله لحتمالات وصول حكومة عسكرية اله اللسطة في طهرانسواء كلتت

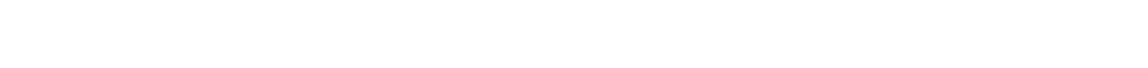

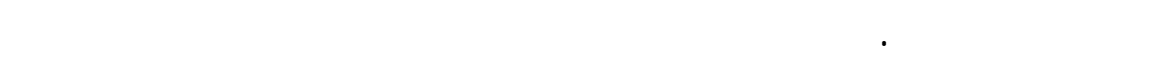

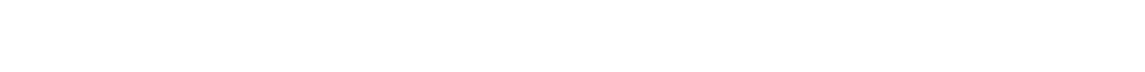

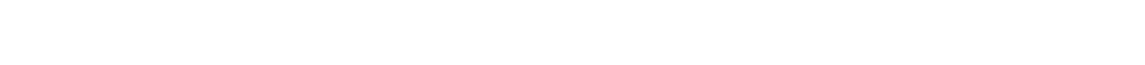

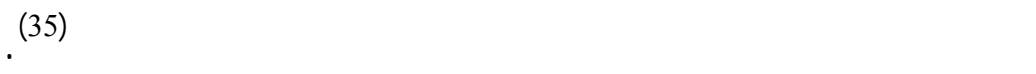

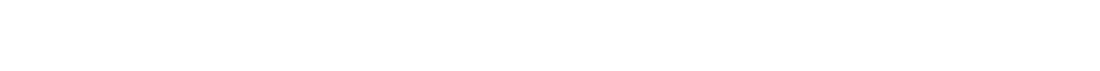

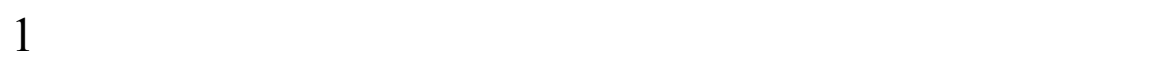

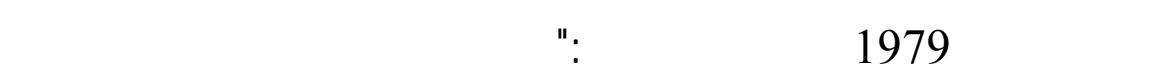

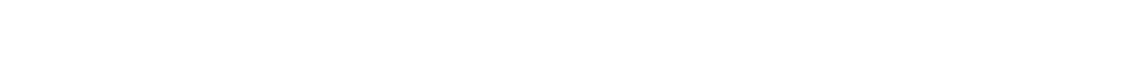

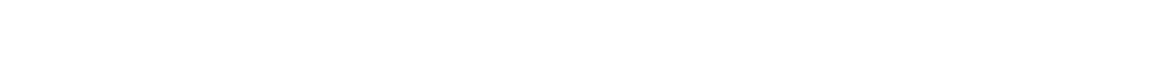

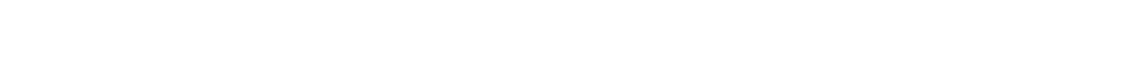

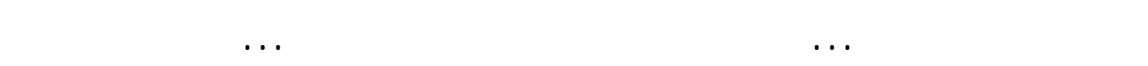

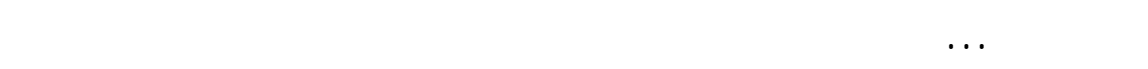
يحصل" (36).

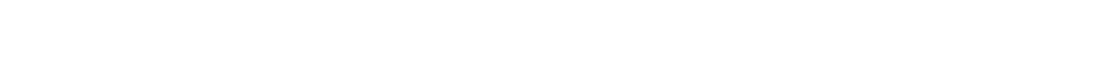

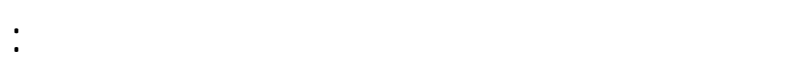

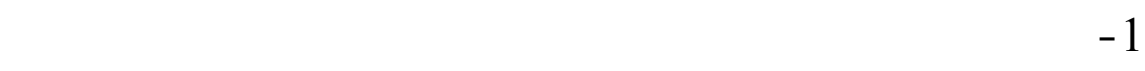
هذه الثرعية. 2 - ان الاحداث الدمية في ليران لا تخدم لحد ولا حتق مصالح الايرانيين

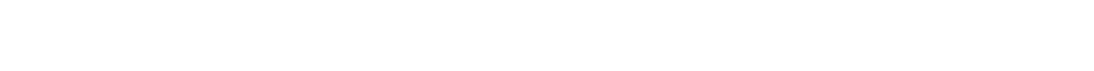
الاحداث بأفنهم. 
3 - ان لستمرار الما يحدث في ايران هو بمثابة تهديد مسنقبلي للمد مقرار

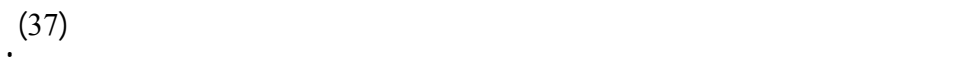

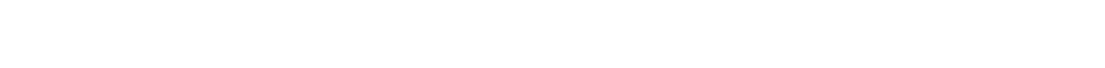
1979 ، وقضت على تبعية ايران العس كرية وللسيلس ية والاقتص الية الفية

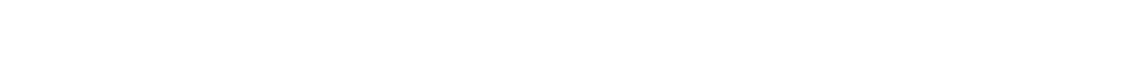

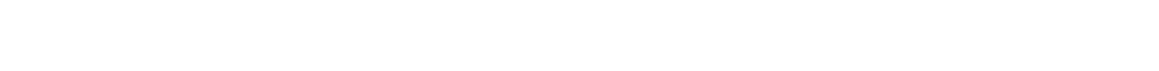

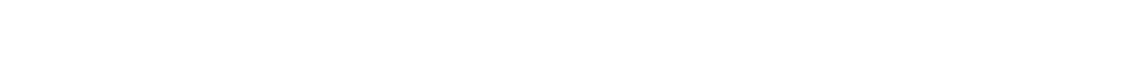

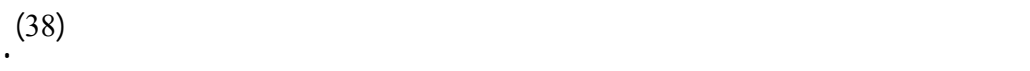

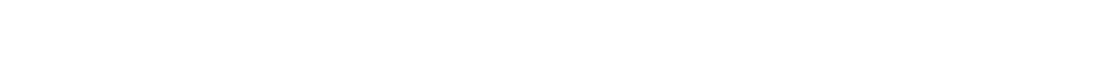

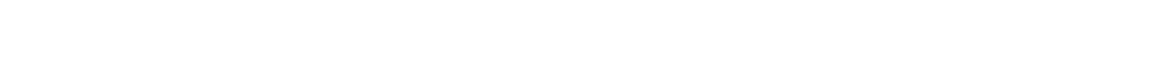

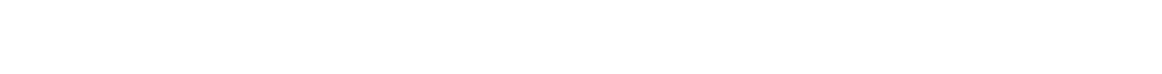

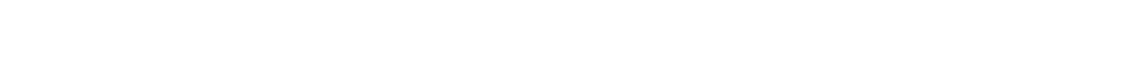

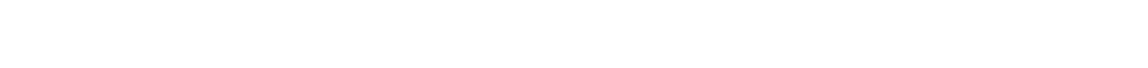

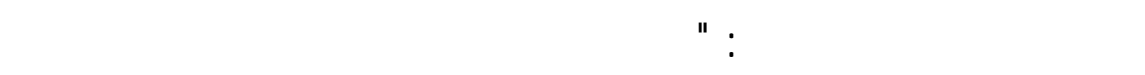

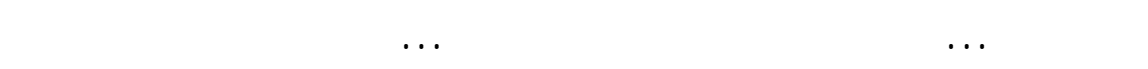

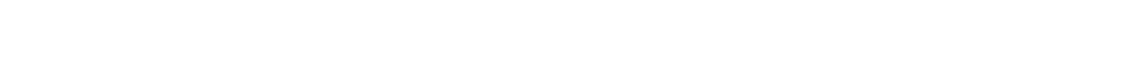

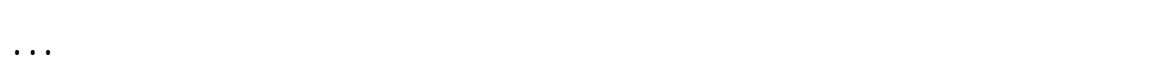

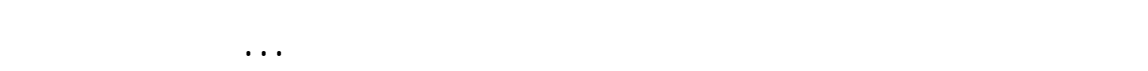

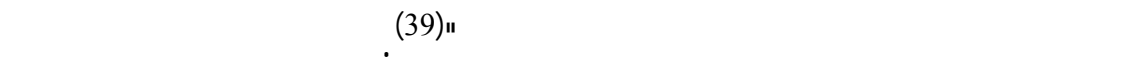

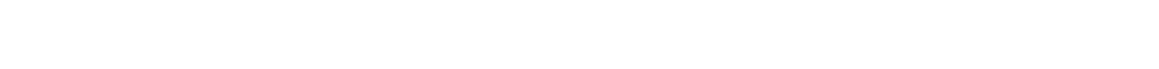

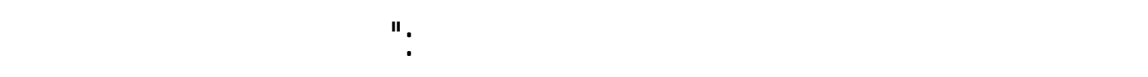

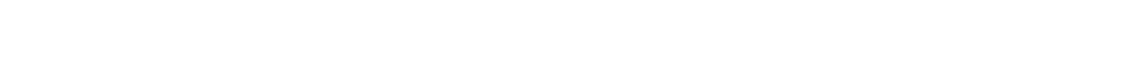

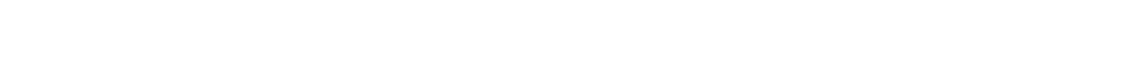




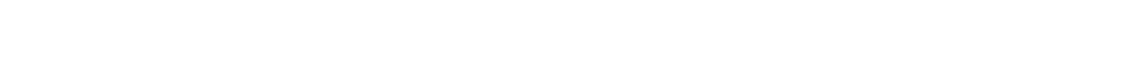
لاراة الثعب الايرالي" (40).

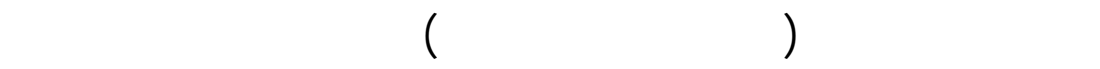

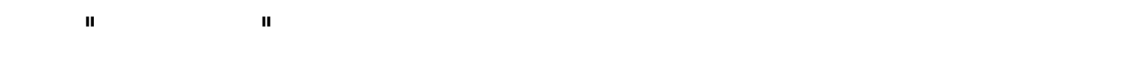

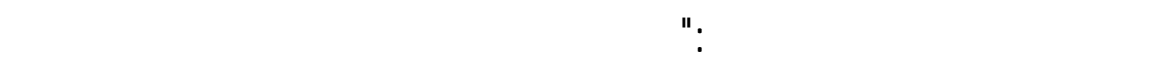

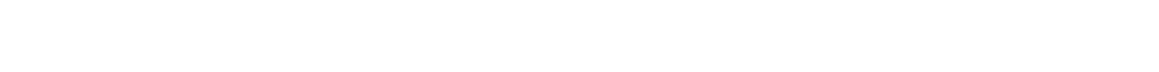

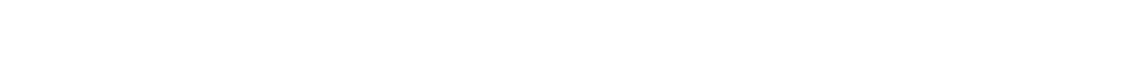

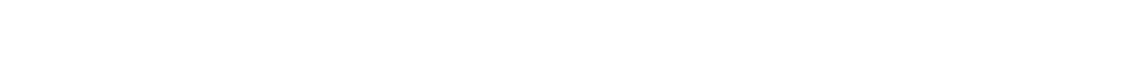

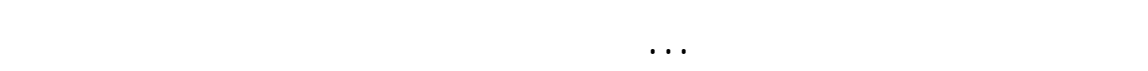

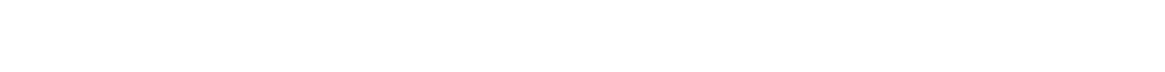

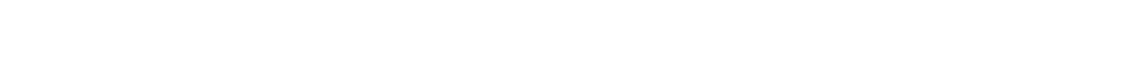

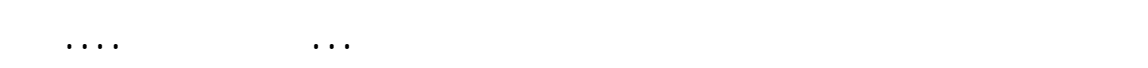

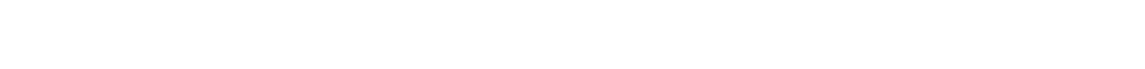

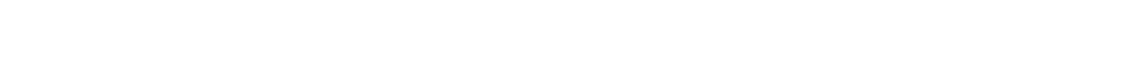

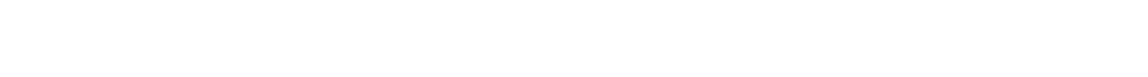
سيجتازها جلالة للثهل "(41).

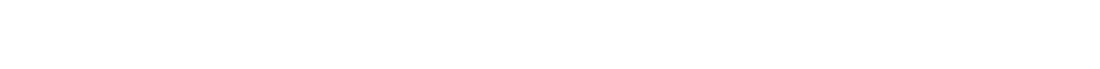

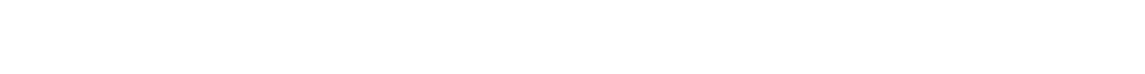

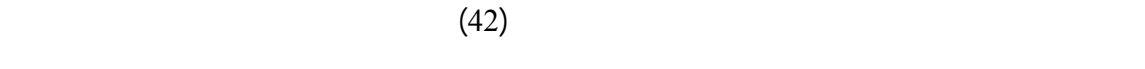

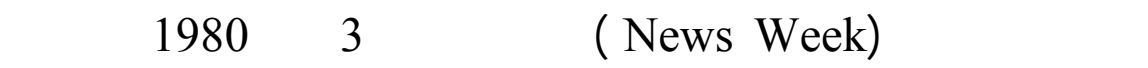

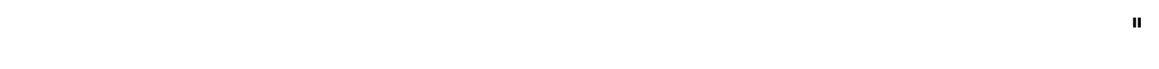

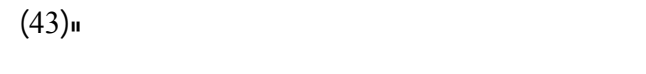




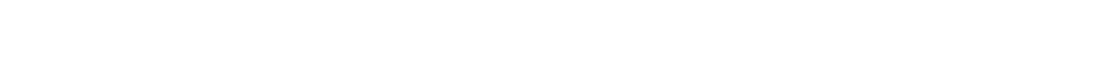

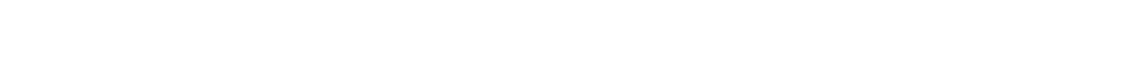
التخذ لسلوبين ازدولجين في التعلمل مع اليران الثورة: -

$$
\text { الاسلوب الاول : - التأييد الظاهري : }
$$

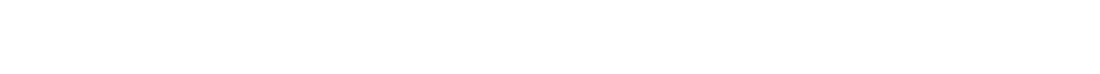

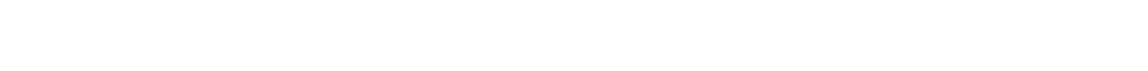

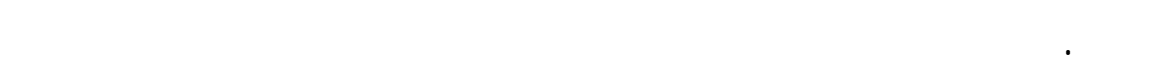

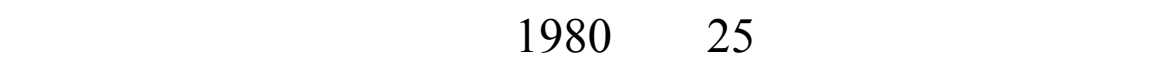

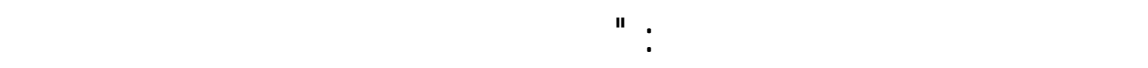

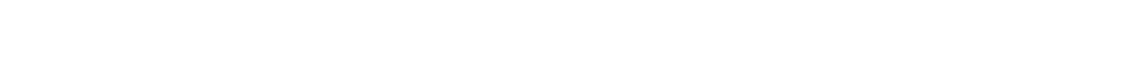

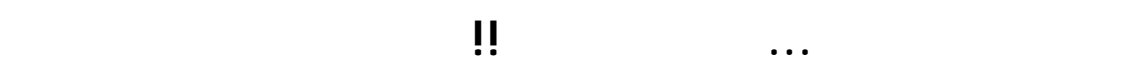

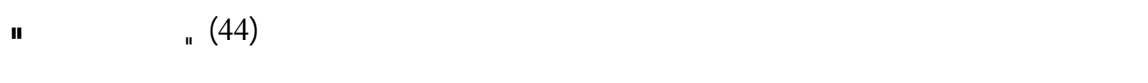

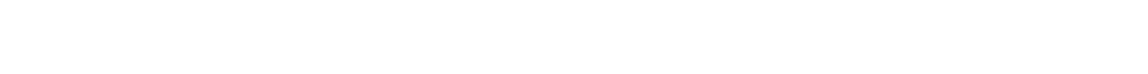

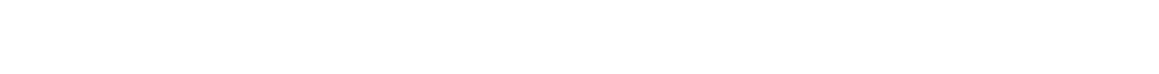

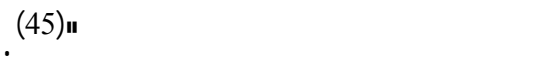
وفي مقابلة لخرى لجراهاسليم اللوزي رئيس تحرير مجلة الميلة الح ـوادث

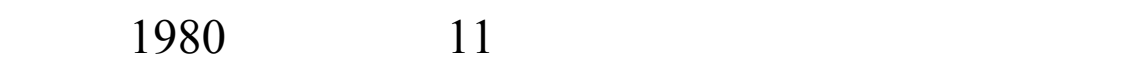

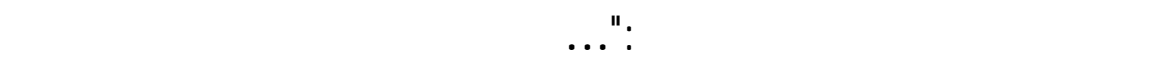

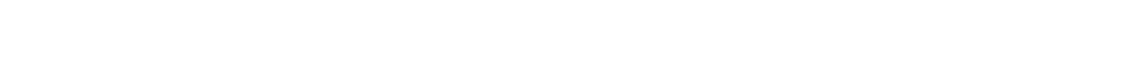

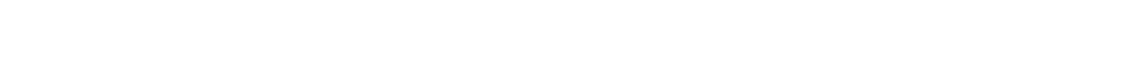

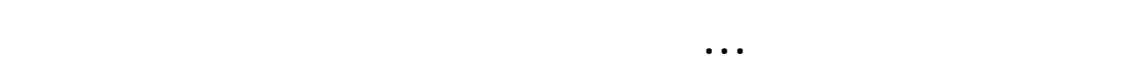




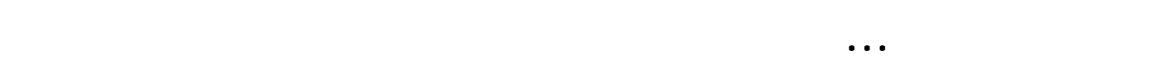

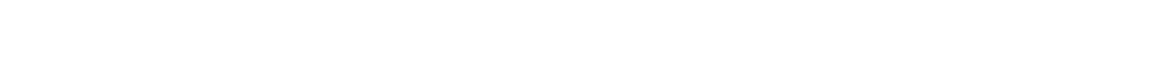

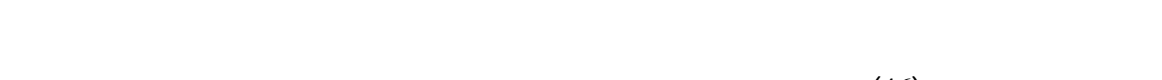

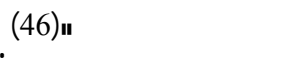
وجاء التأييد الظاهري للمملكة العربية للسعودية لثورة ليران الإلامية من عدة لسبلب اهمها:

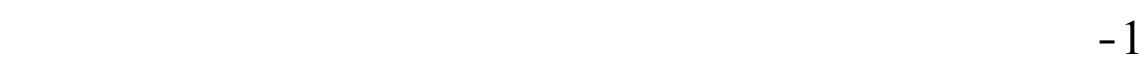

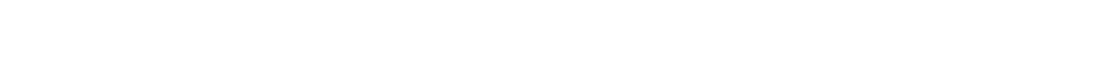
العربية .

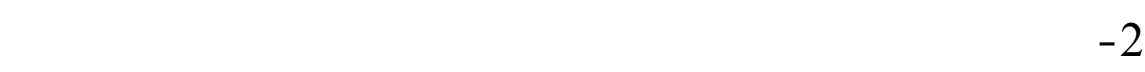

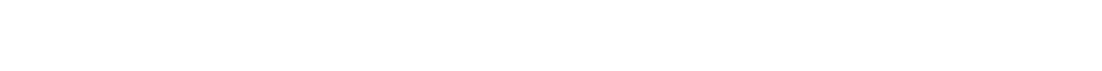

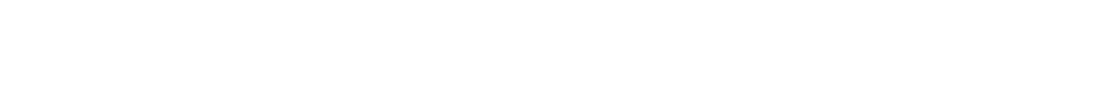
التأييد خير٪(47).

$$
\text { الاسلوب الثاني: - همارضة الثورة: }
$$

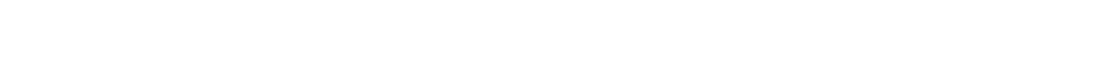

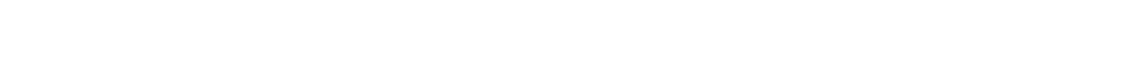

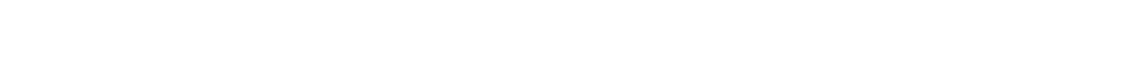

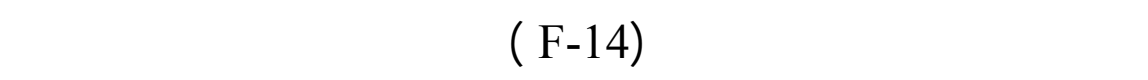

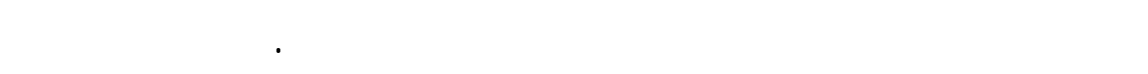

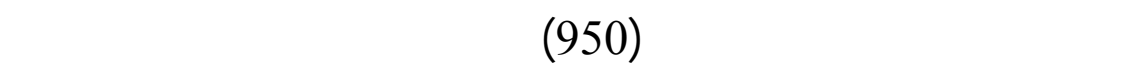

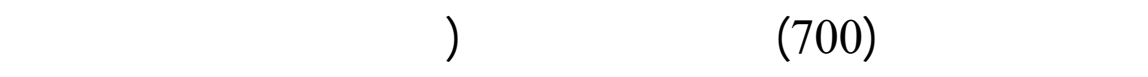


الامريكية). فضلاً عن معارضة اللسعودية للثورة في المؤتمرات الاقليمية

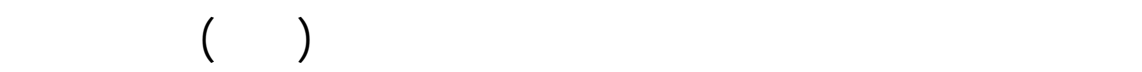

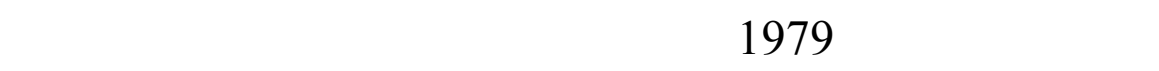

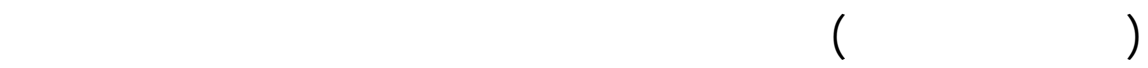

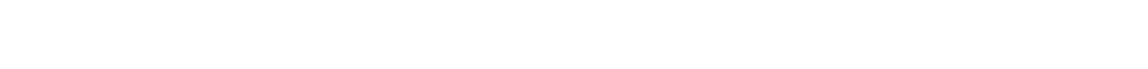
اعلاه الله بلده قبل ان ينهي المؤتمر اعماله (48).

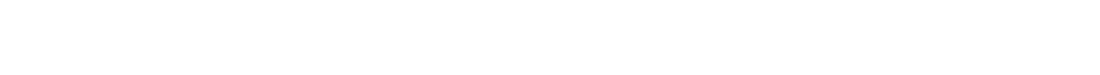

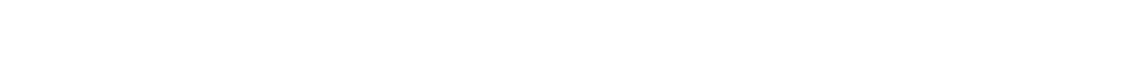

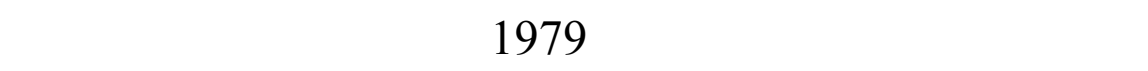

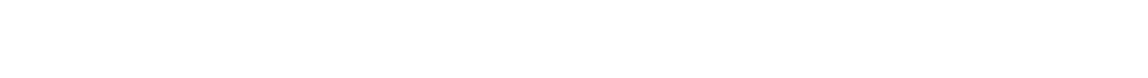

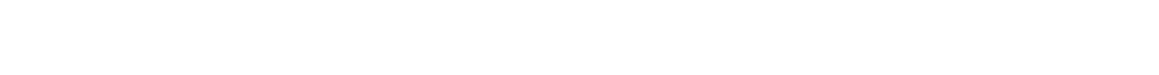

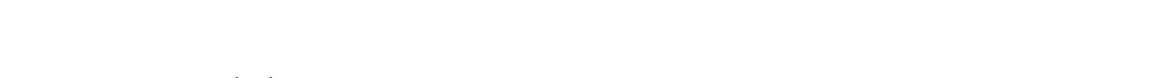
الاقتصادية وكما نكرنا ذلك مسقاً المع المصالح الإنهرية المريكية (49).

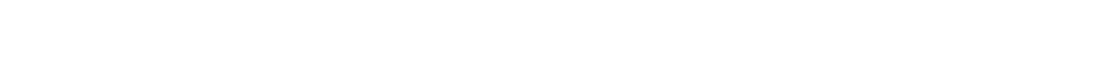

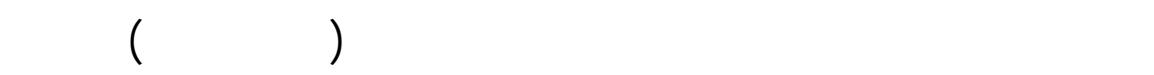

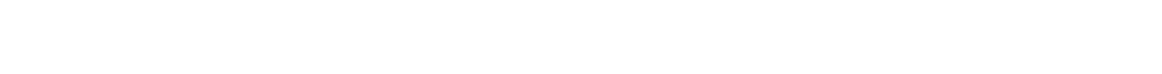

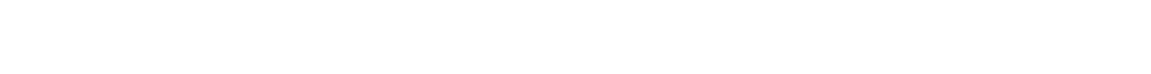

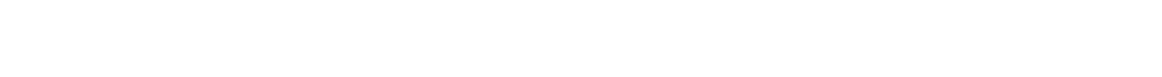
ققدر بـ ــ (10) ملايين دولار (50). وفي غمرة التهيدات الامريكية للحكومة الايرانية الجدية بعد لحتجاز

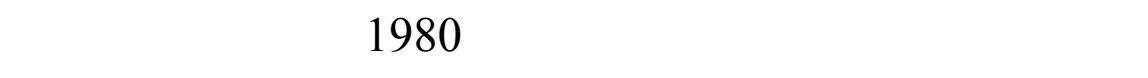

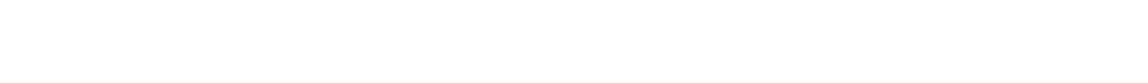
فرقة عسكرية امريكية كبيرة، وهذا ما لكته صحيفة (جمهوري لسلالمي) 
الايرانية التي اضفافت معلوملت فيد بأن قسماً م ن الق _وات الامريكي ة

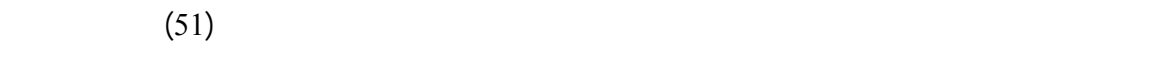

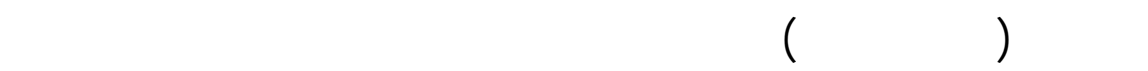

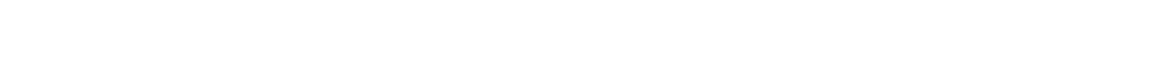
بعض المستشارين الفنين والعسكريين الامريكان في اللسعويةية" (52).

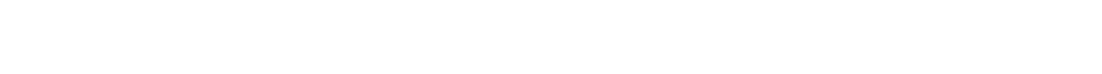

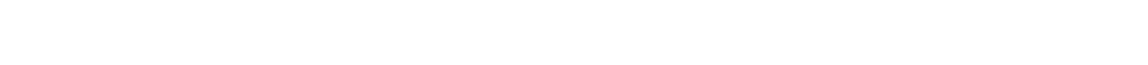

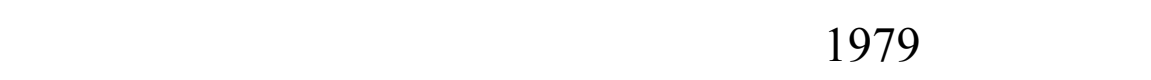

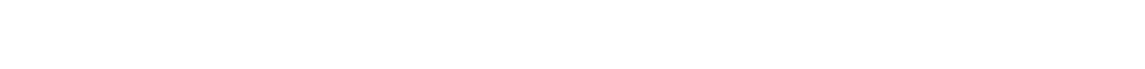

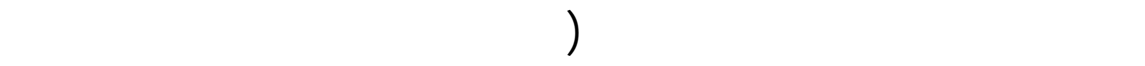

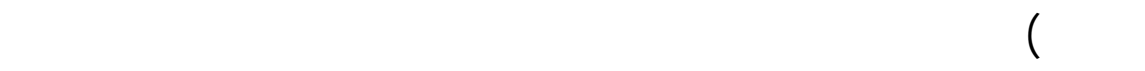

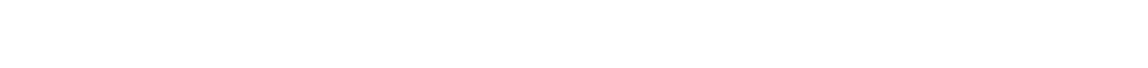
جماعلت تمولها الحكومة الايرانية (53).

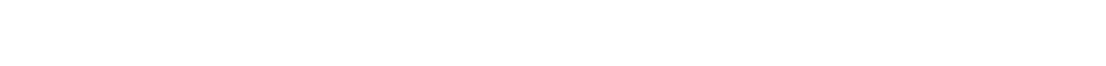

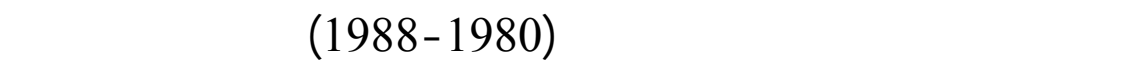

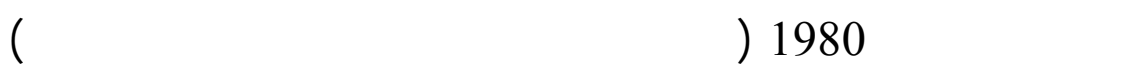

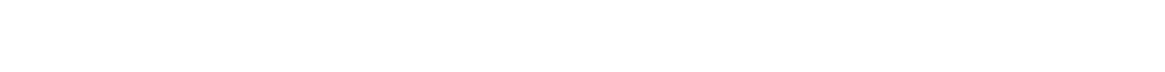

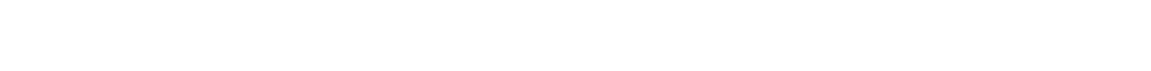

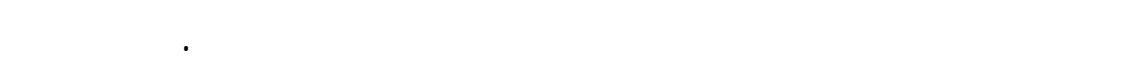

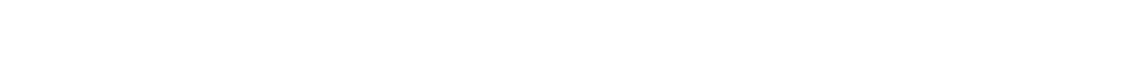

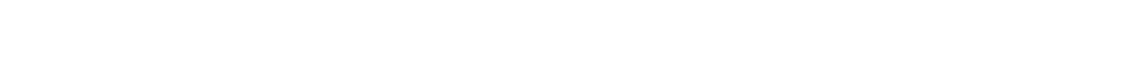

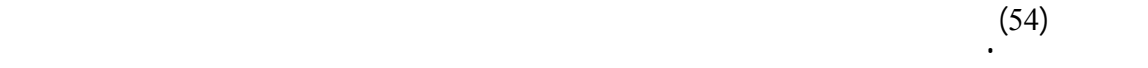


ويتجله الموقف للسعودي المناوى لايران اثناء تلك الح ـرب ، ف مي

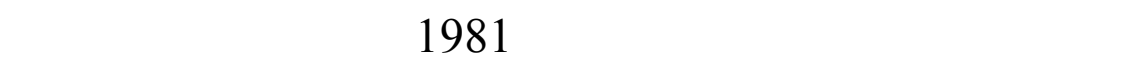

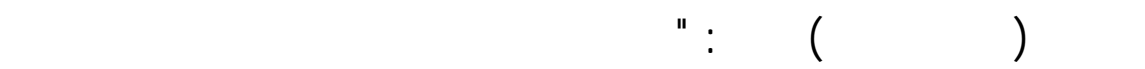

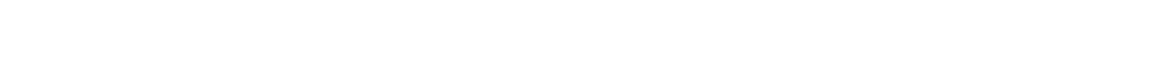

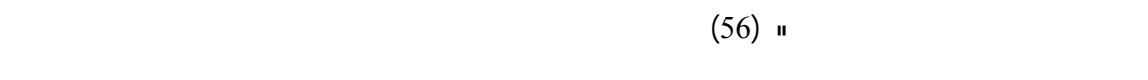

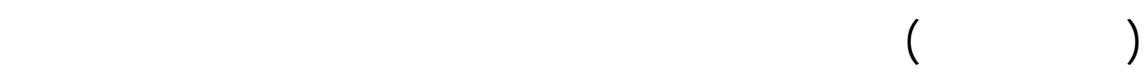

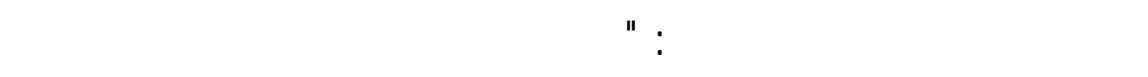

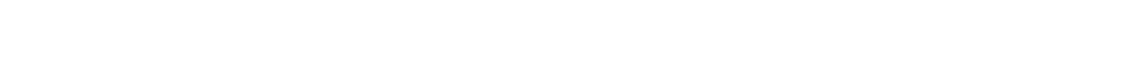

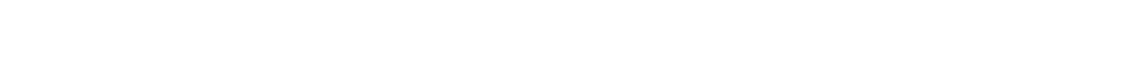

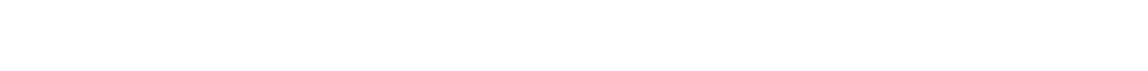

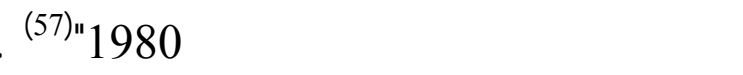
ونكرت صحيفة (الرأي العلم) الكويتية "لن اللسعودية قدمت مس المس اعدات للعراق بلغت في نيسلن 1981 حوالي (6) مليارات دولار (58) كما زونته

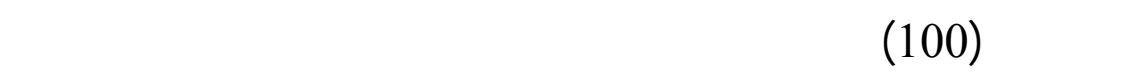

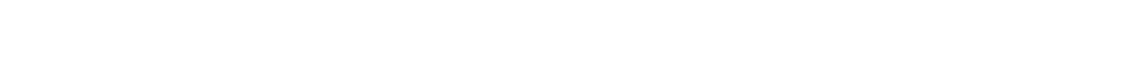

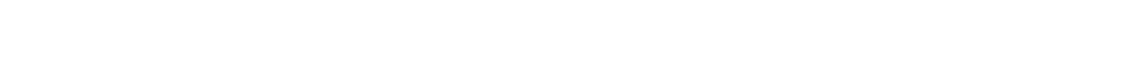

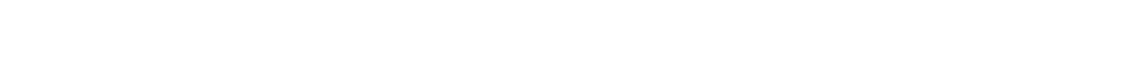
للعراق" (59).

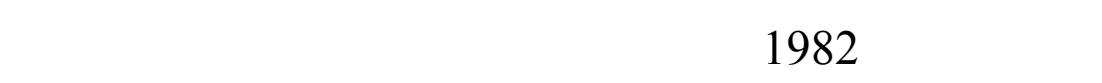

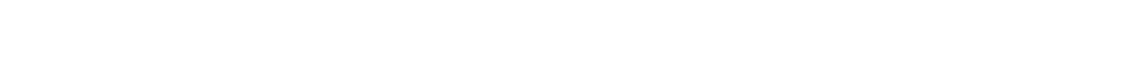

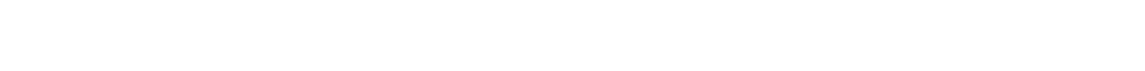

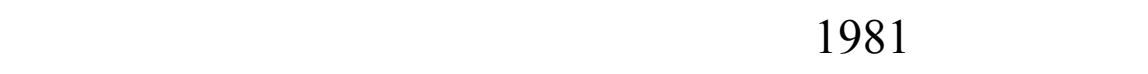
الذين لم بستغلو هذه المنلسبة الدينية للاغراض اللسيلسية، اذ قلم الحج الجياج 
الايرانيون بمسيرات ومظاهرات في مكة والمدينة ورفعوا فيه L صـ -ور

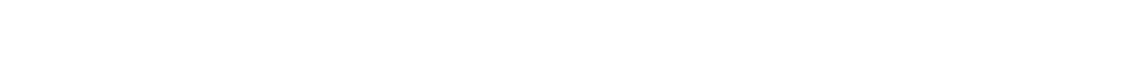

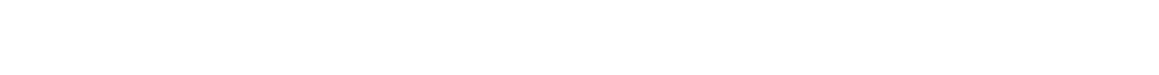

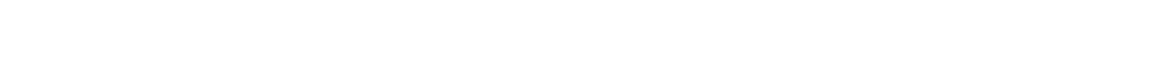

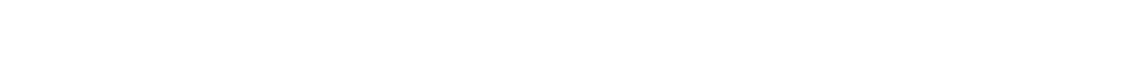

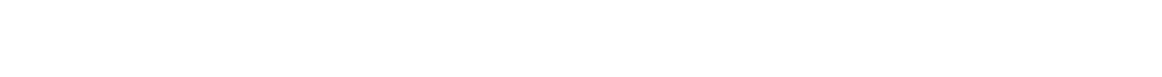

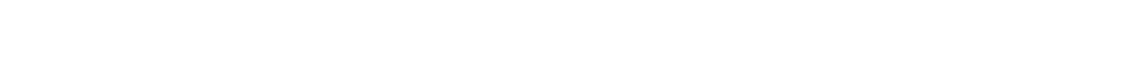

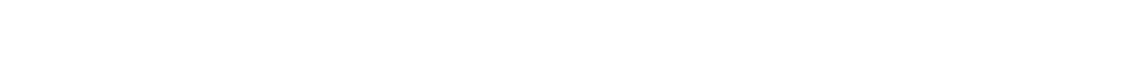

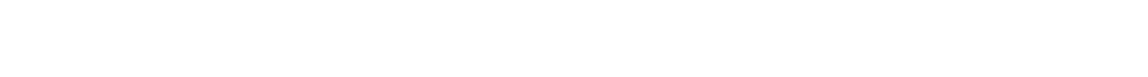
التي وزعت على كرلسلت ومنشورات ف مي الح ـرم الملك مي الثد ـريف.

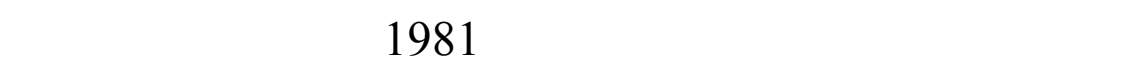

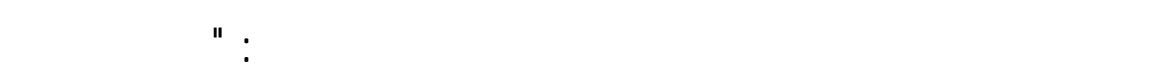

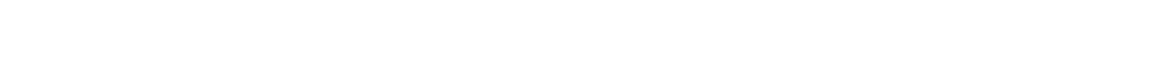

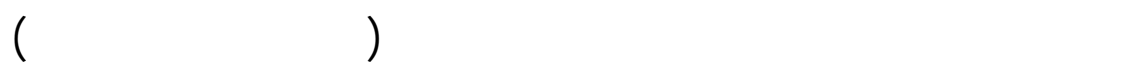

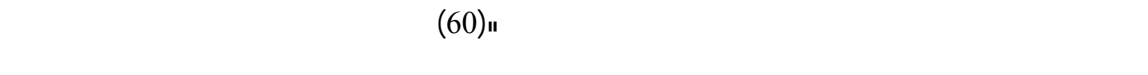

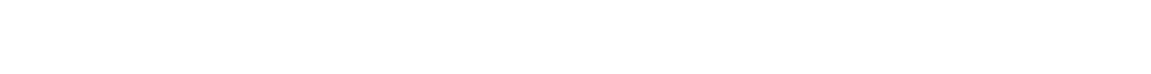

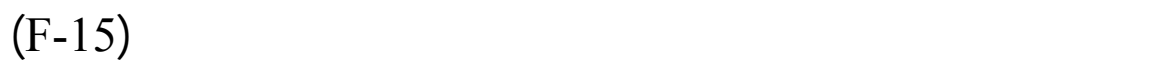

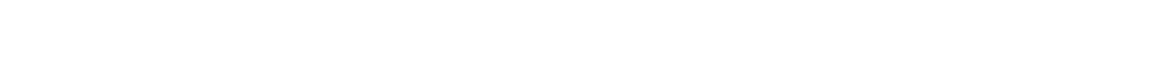

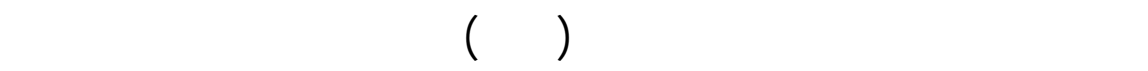
صرحت به الحكومة للسعونية (61.

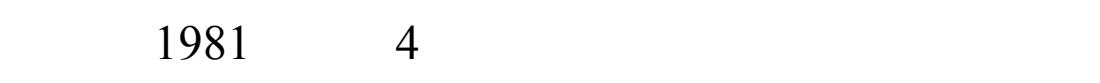

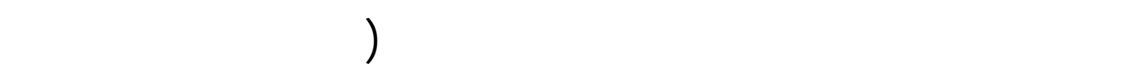
لتعمق الروابط بين الظار الخلبج العربي) تحقيق اهداف عسكرية والمنية 
لاقلمةسد رفاعي في مولجهة الثورة اللسلمية الايرانية في المطقة، حيث

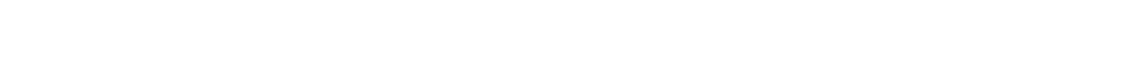

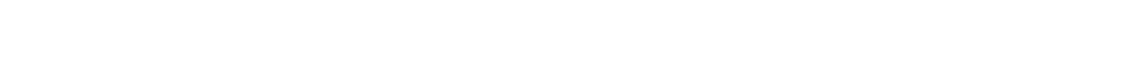

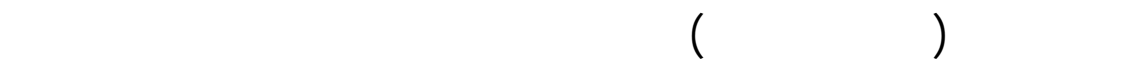

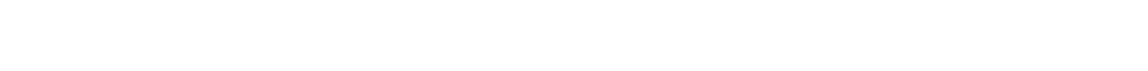

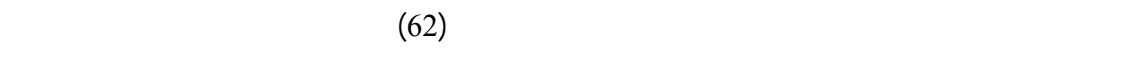

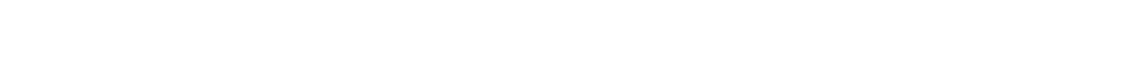

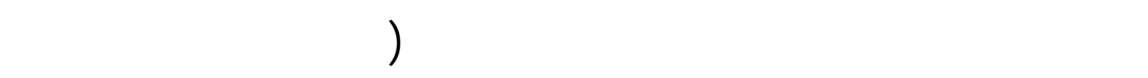

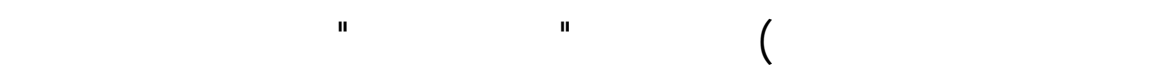

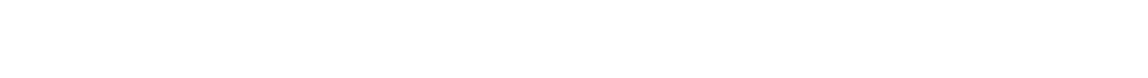

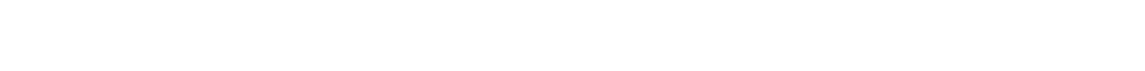
الظرف، واقلمة معسكرات التدريب (63).

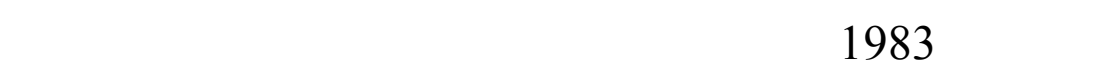

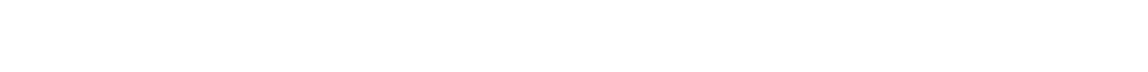

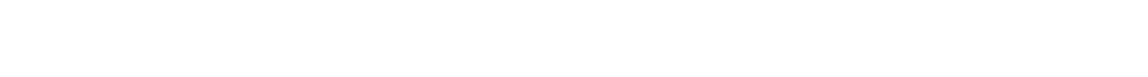

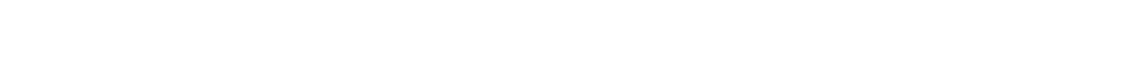

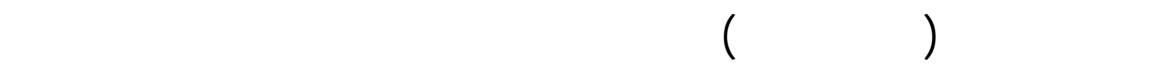

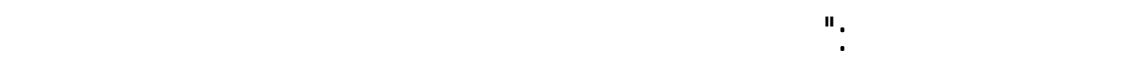

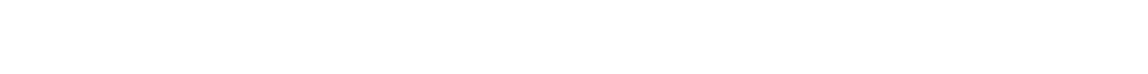

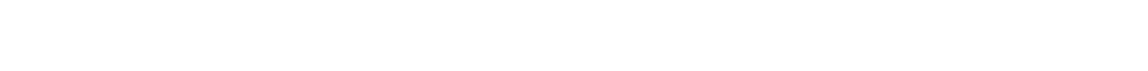

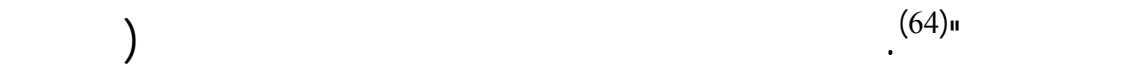

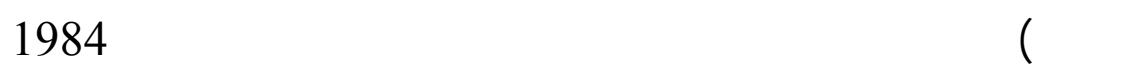

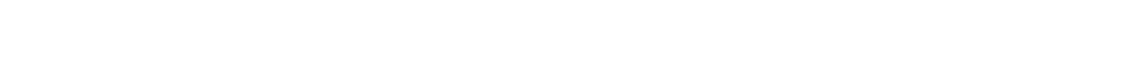


حكومته وحكومة الكويت والبحرينستساعدان عل م لطف اء ذ ار تلـ لك الحرب(65).

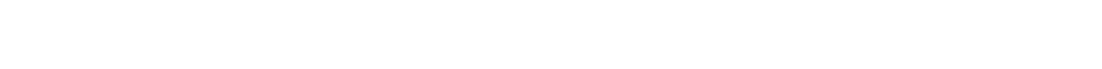

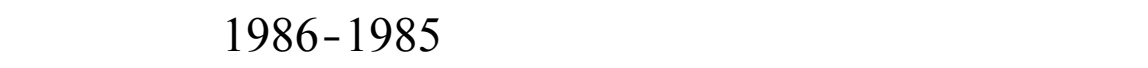

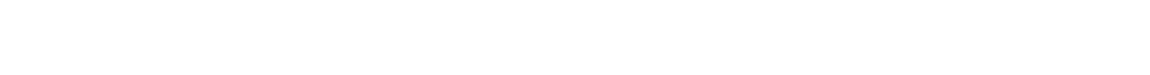

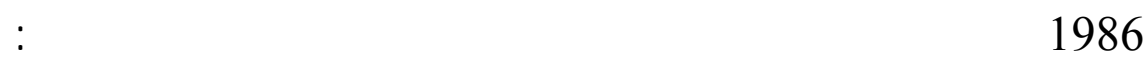

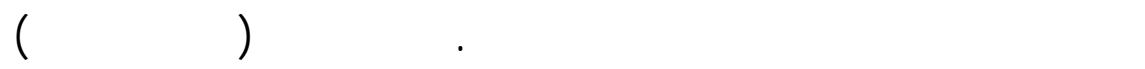

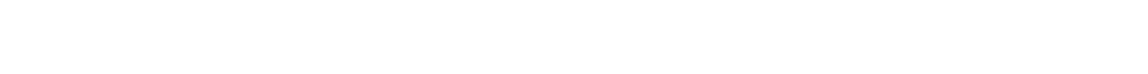

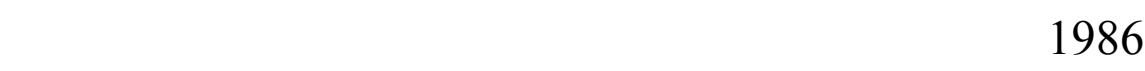
وخصوصاً انهاء الحرب بين العراق وليران، والحيلولة دون النتشار تأثير الئير

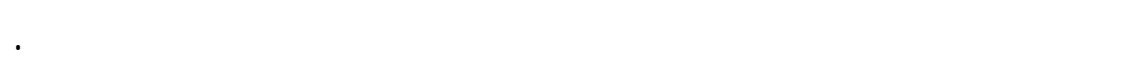

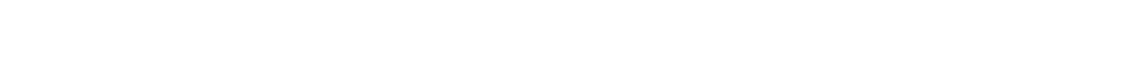

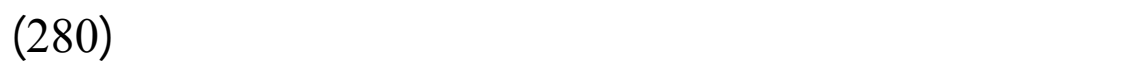

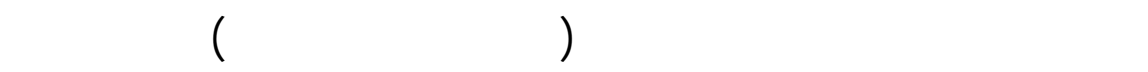

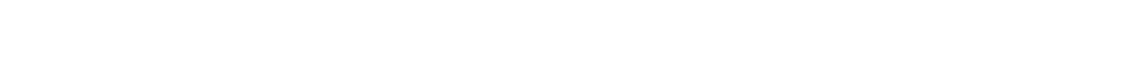

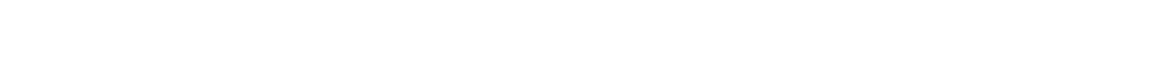

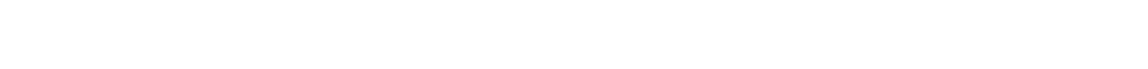
الضرورية (66) .

وصلت الخلافلت الايرانية للسعودية لشدها على اثر الهبوط في لسعار

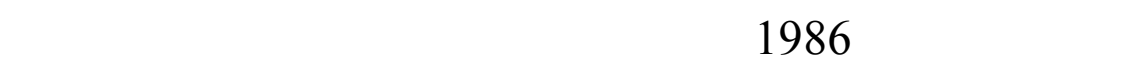

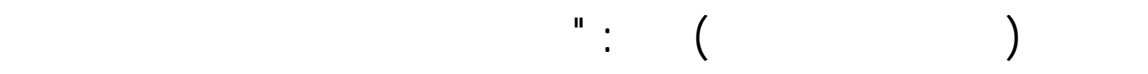

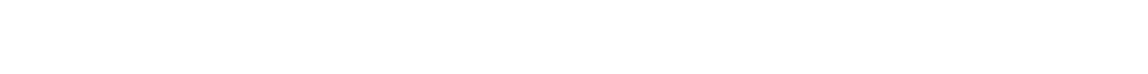

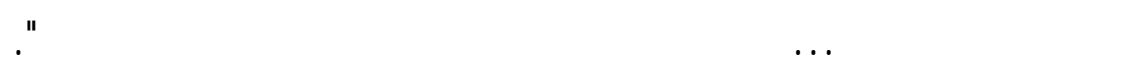




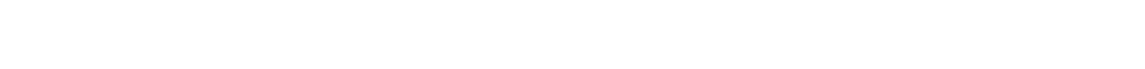

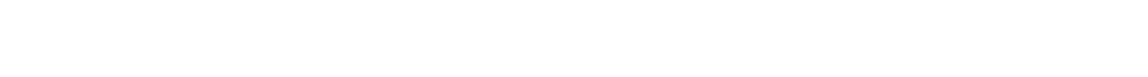

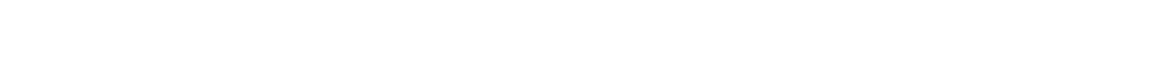

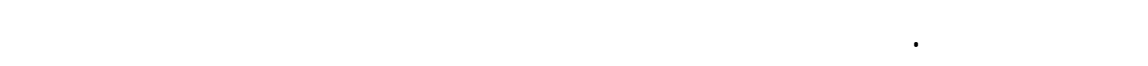

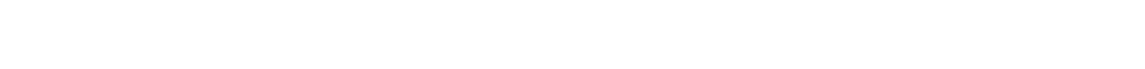

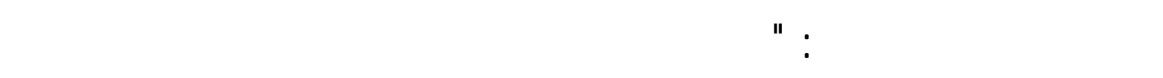
الالمسعار ترفعع" (67).

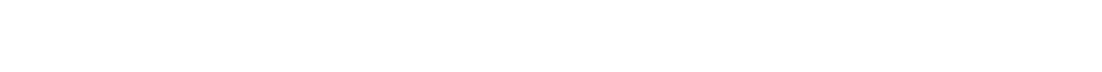

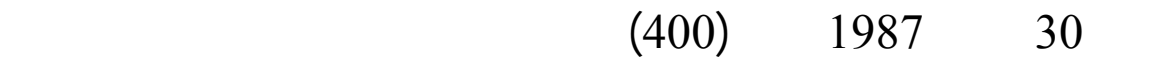

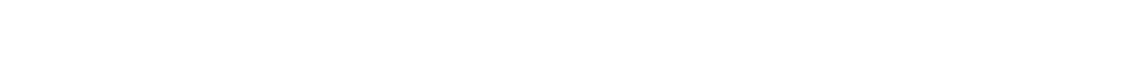

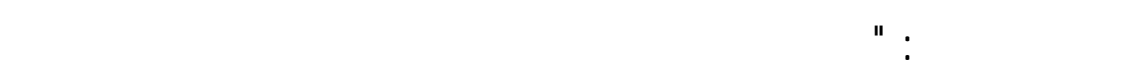

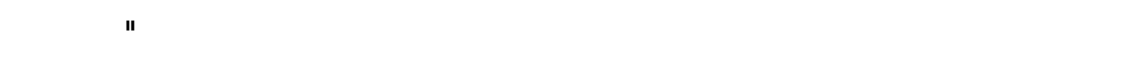

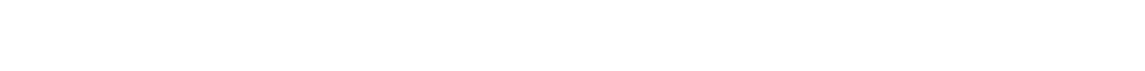

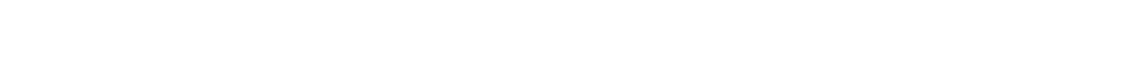

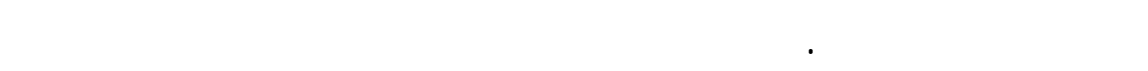

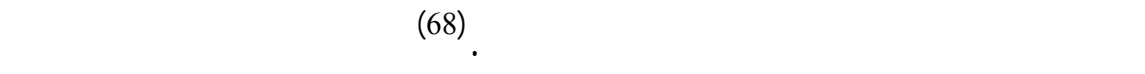

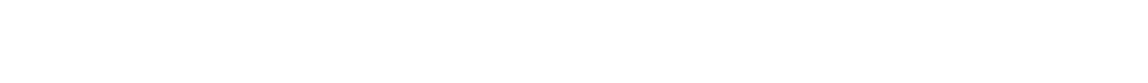

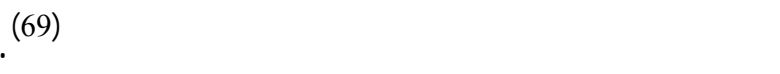

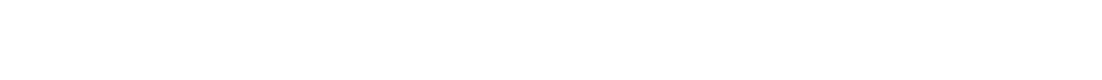

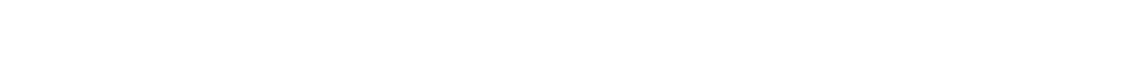

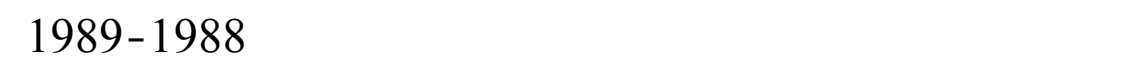

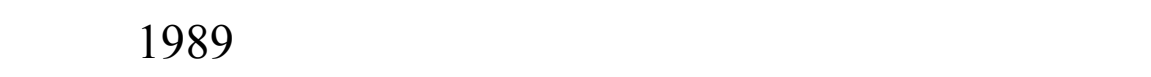
الدبلوملسين من اراضييها. وقد فشلت وسطالت لكل من (ليبيا والجزائ ـر 
وسوريا والارن) من لجل الوصول اللى وعدمن الجلب الايرلي بالكف

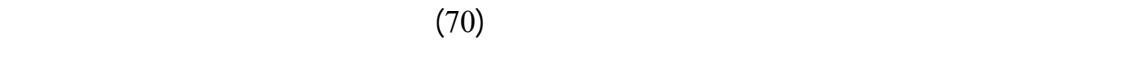

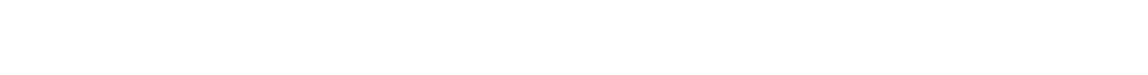

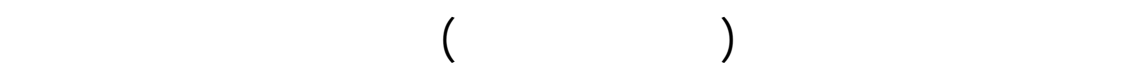

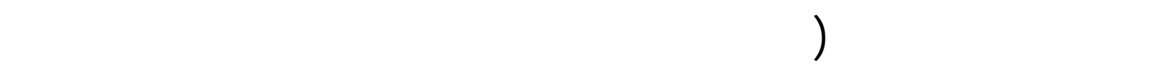

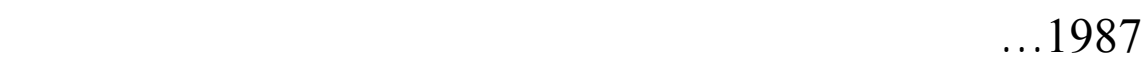

وتعرضها لحرية الملاحة القامة من واله موالفى المملكة) (71).

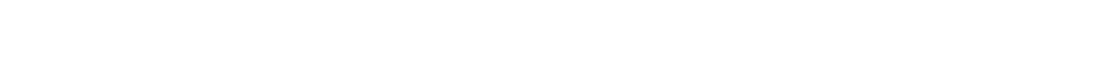

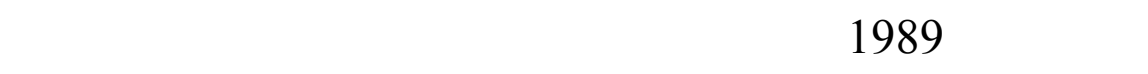

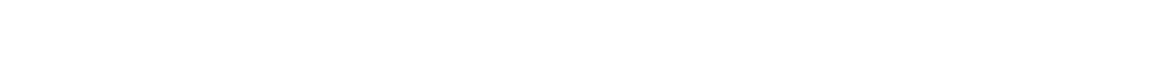

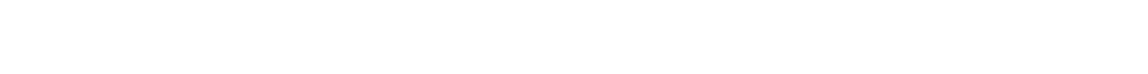

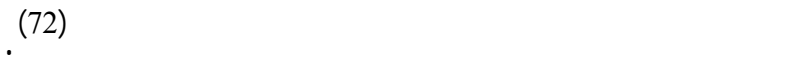

\section{- المرحلة الثانية : 1989-1997}

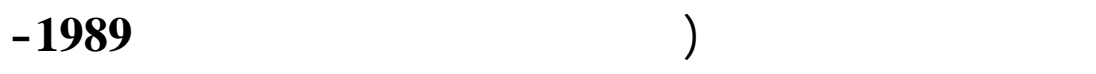

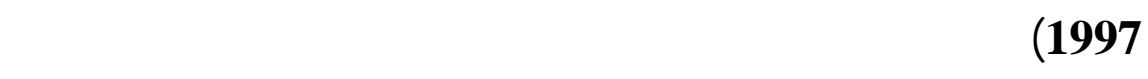

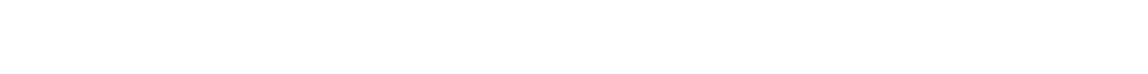

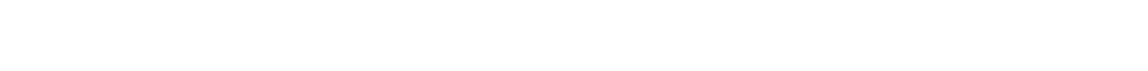

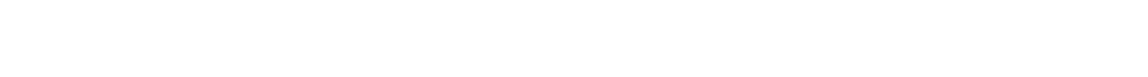

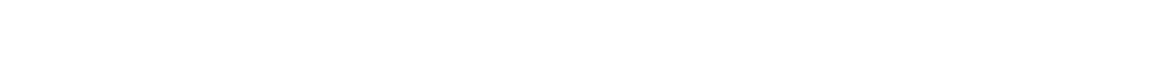
الني كقدت بين الطرفين في جنف خلالش بلط 1989، وت م حض -ور 
ايرلن لجتماع مظمة المؤتمر الاسلامي الذي كقد في مدينة جلة في اذار

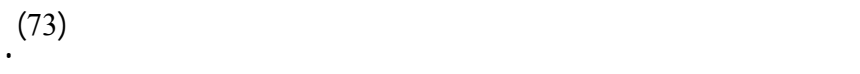

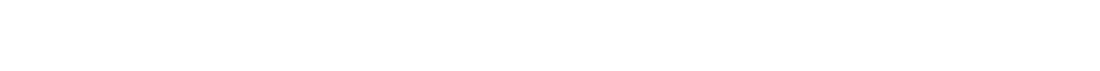
الاقليمية والدولية كان لها الثر على اللسيلسة الخارجية الايرانية منها لخدول

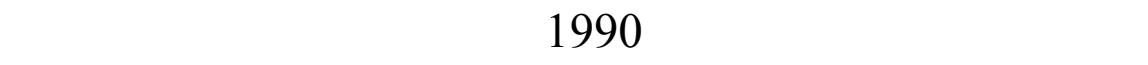

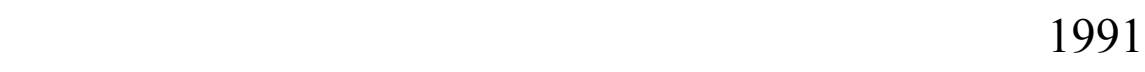

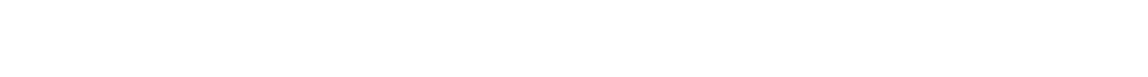

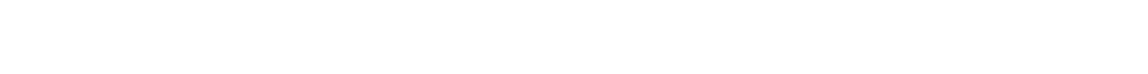

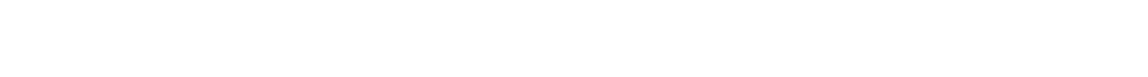

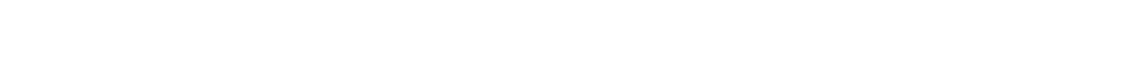

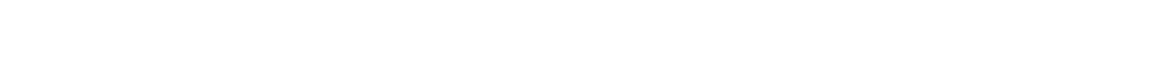

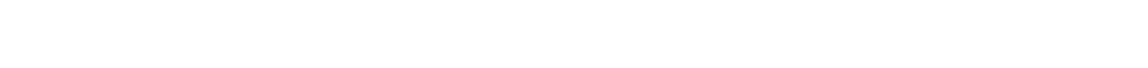

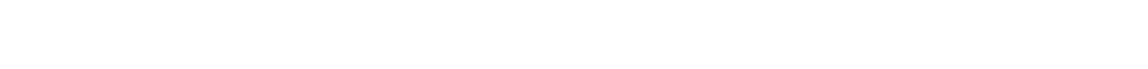

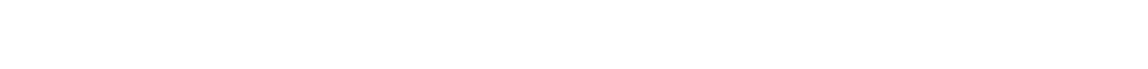

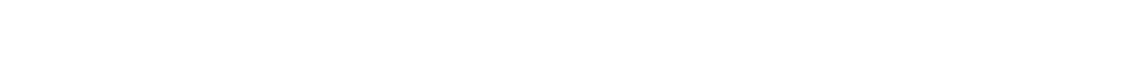

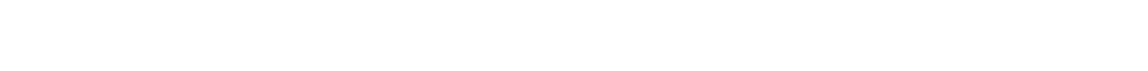

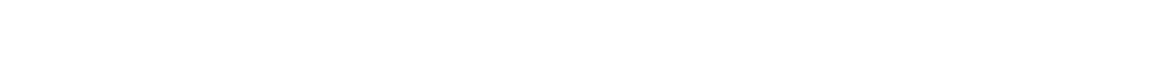

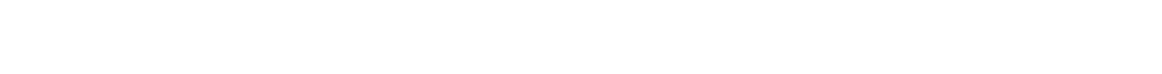

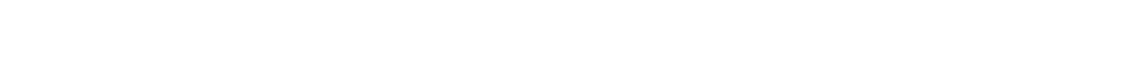

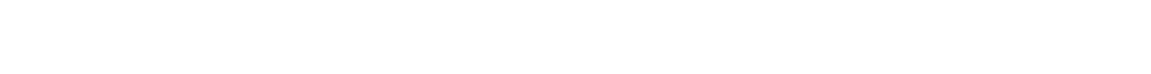

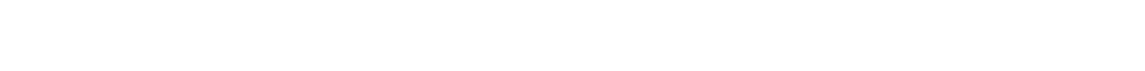

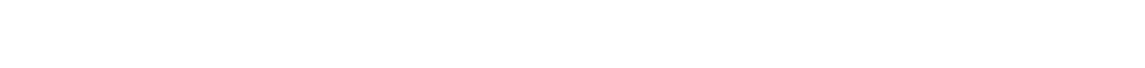
والاقتصاية والعسكرية في الخلبج العربي (74). 
وفي ظل معطيت الواقع للسيلسي والدولي الجديد وجدت ايران فنها

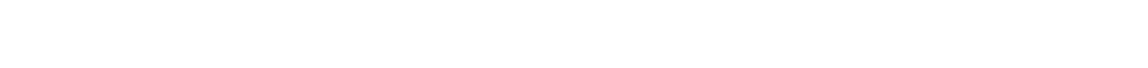

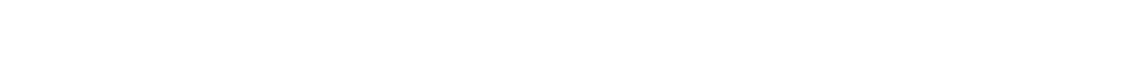

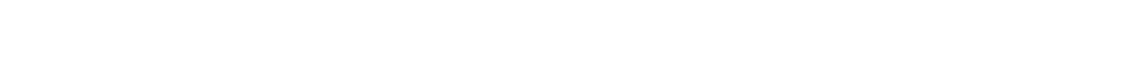

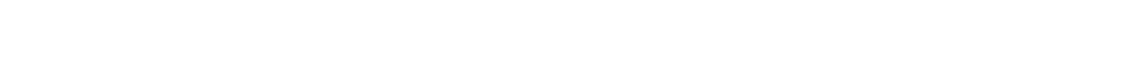

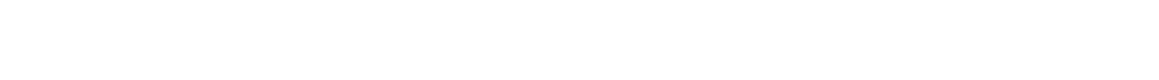

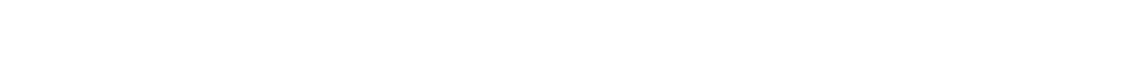

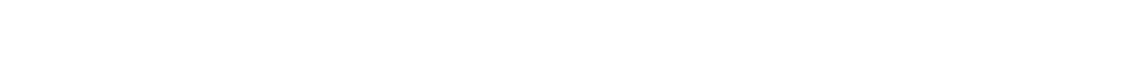

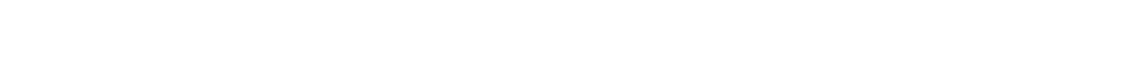

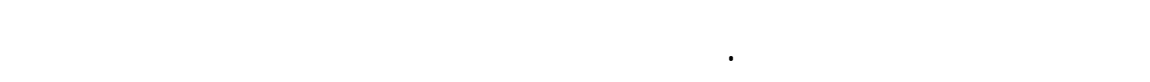

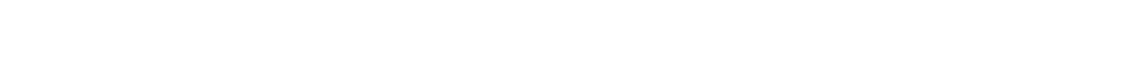

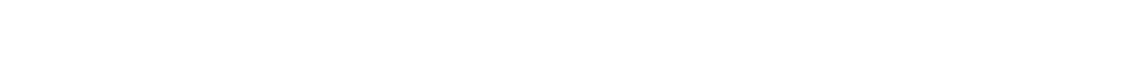

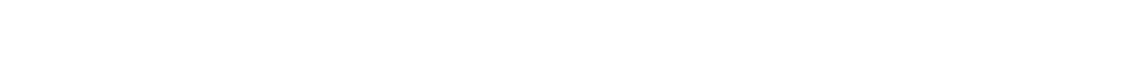

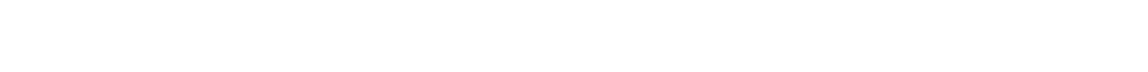

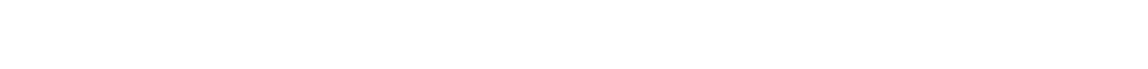

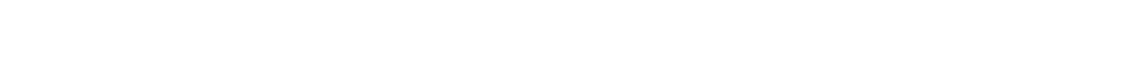

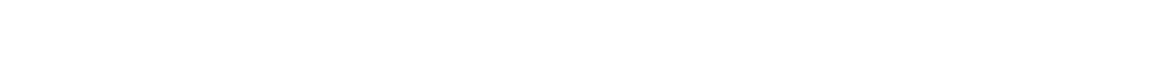

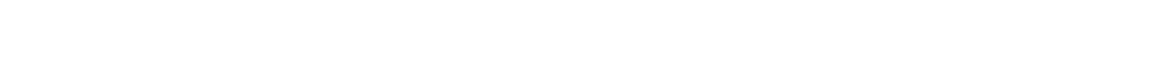

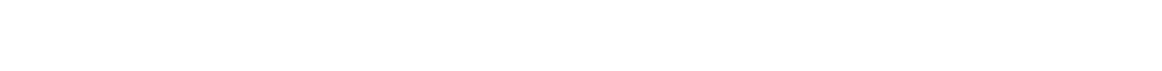
في الحدمن النتشار فوذ الاخرى في تلك الدول (75).

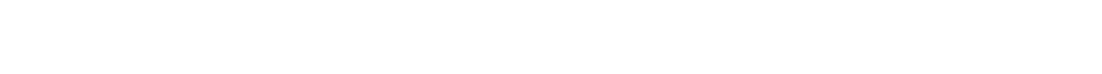

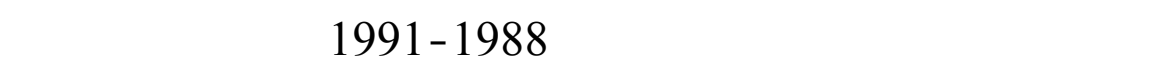

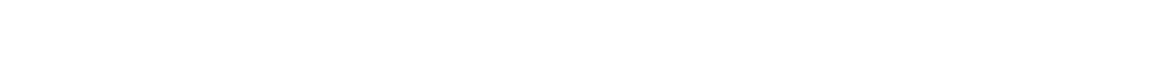




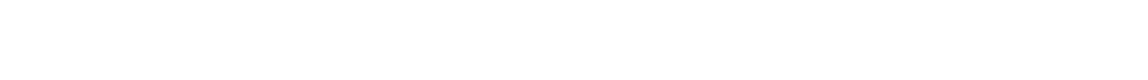

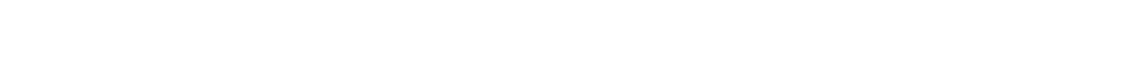

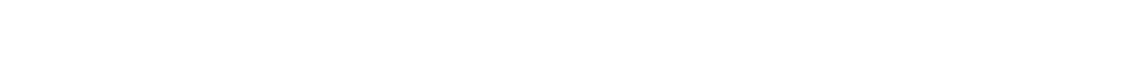

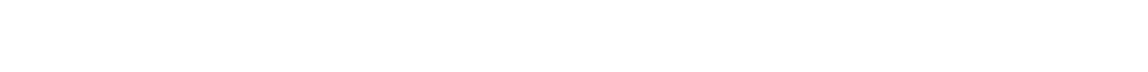

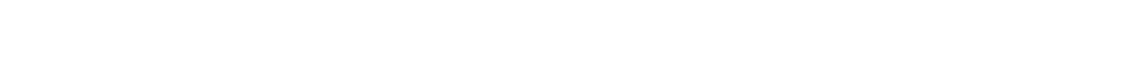

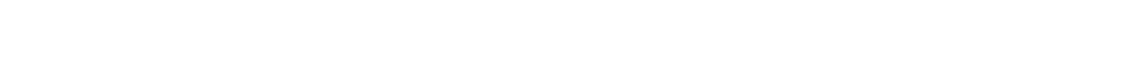

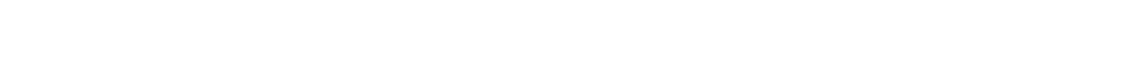

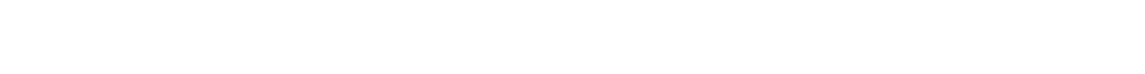

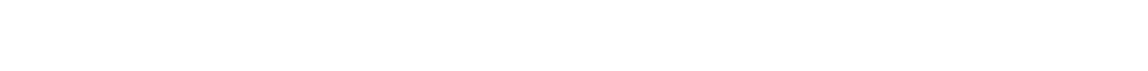

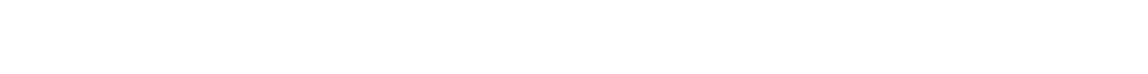

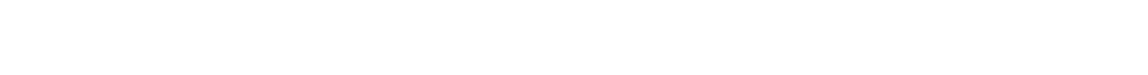

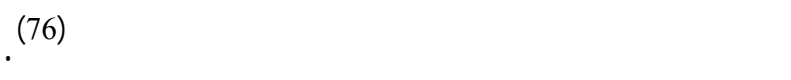

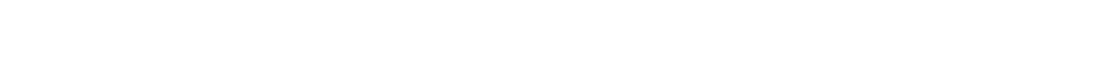

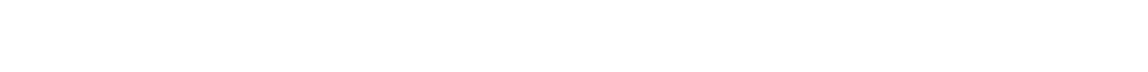

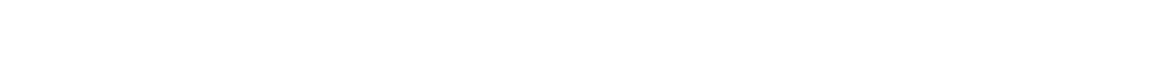

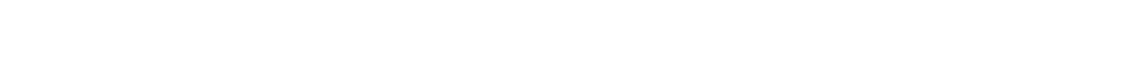

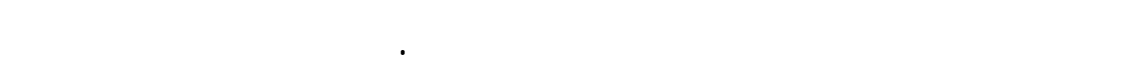

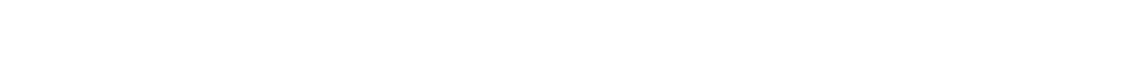

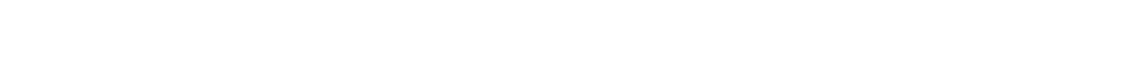

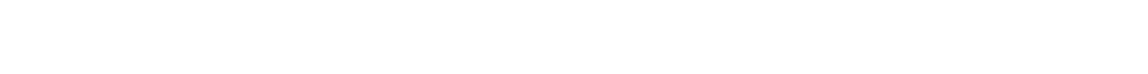

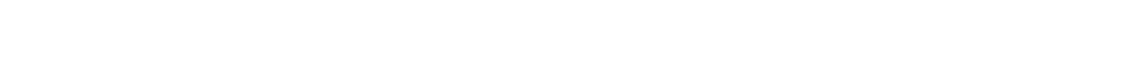
البلاء على المستوى الاقتصادي، وفي لاعار تحقيق هذا الهذف رأت الت اليران

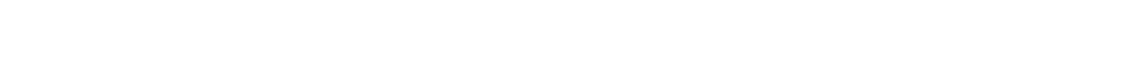




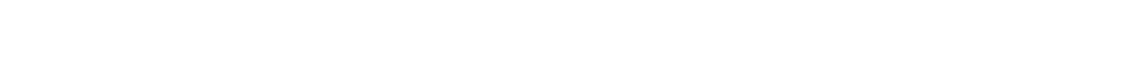

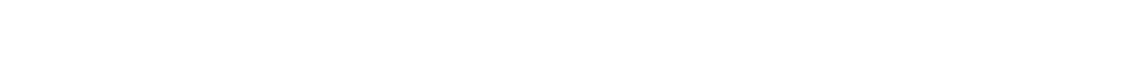

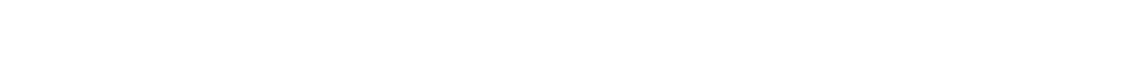

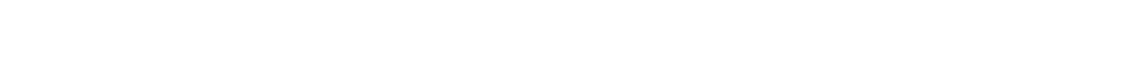

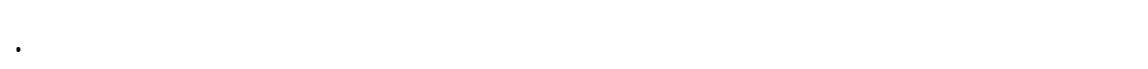

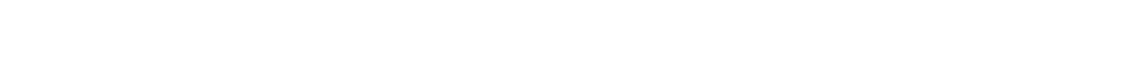

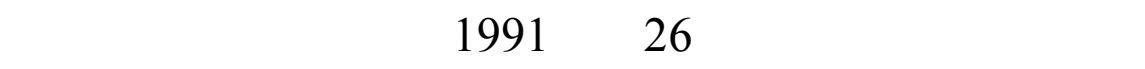

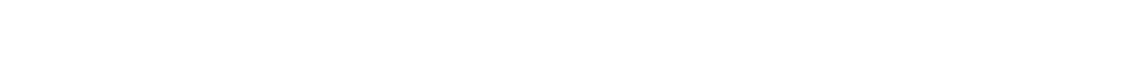

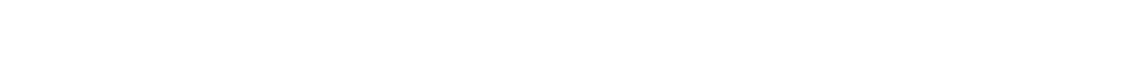

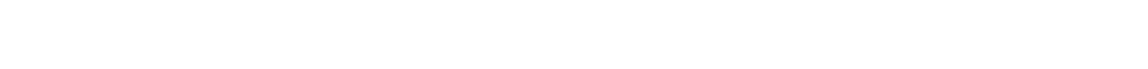

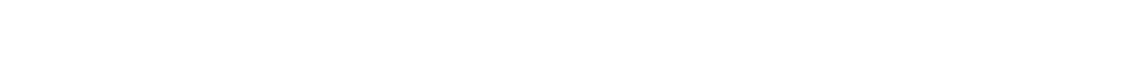

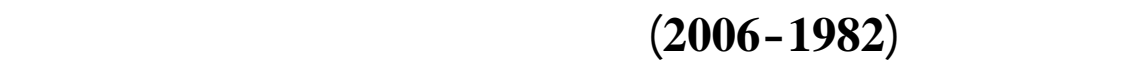

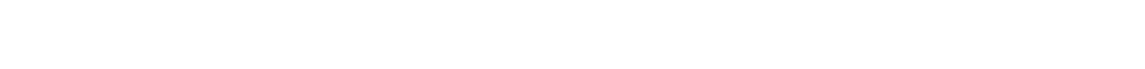

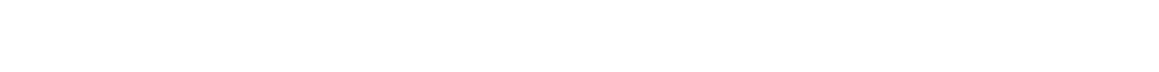
البلنين (77). وهكذا فقدر ما آلت اليه للسعودية وقية دول مجلس التعاون الخليجي

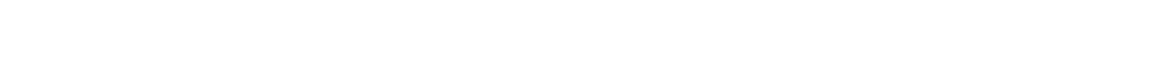

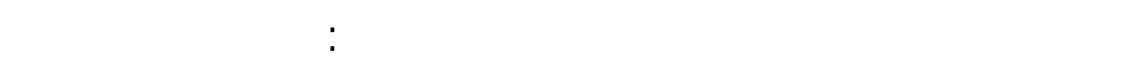

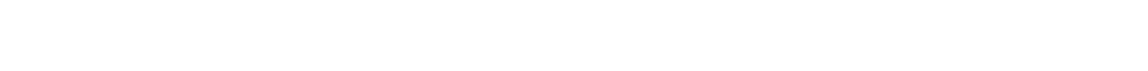

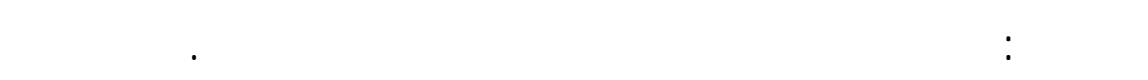

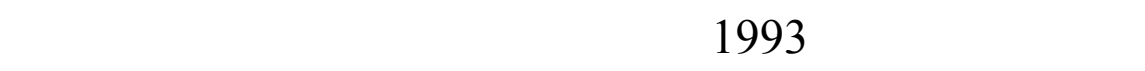

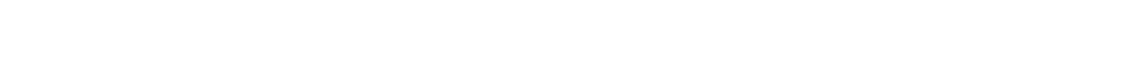

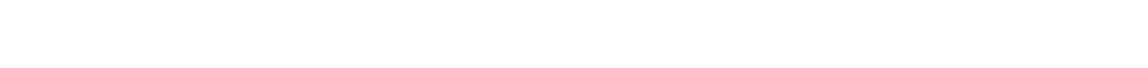


حدث بالفعل . الا ان دعوة ايران للملك فهد نجم عنها خلافلت دلخلية ف ي

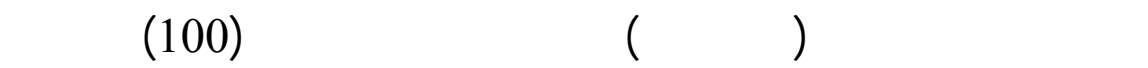

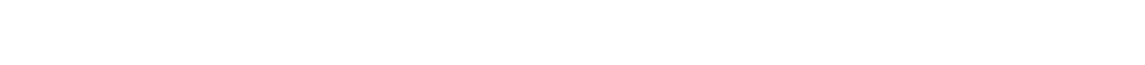

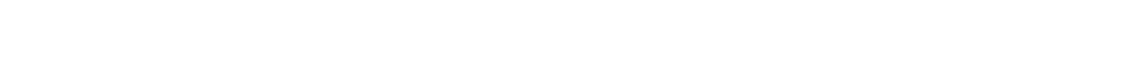

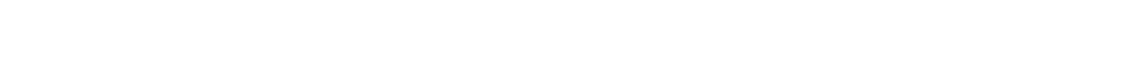

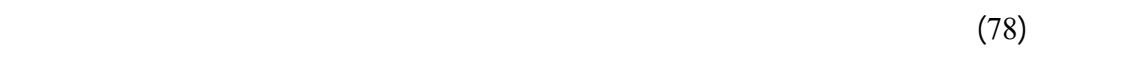

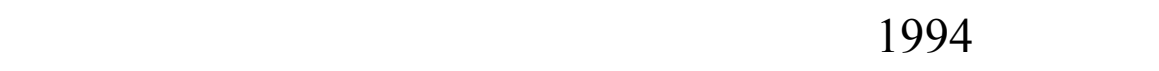
بينهما

ومع حلول علم 1995 قفأم التوتر بين الج انبين وتحدي دأ ف ي 13

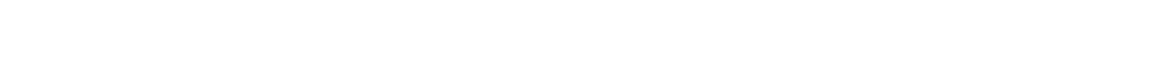

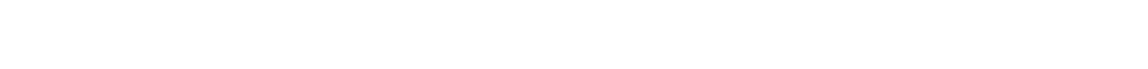

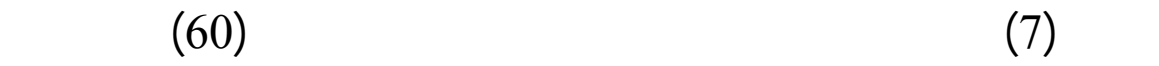

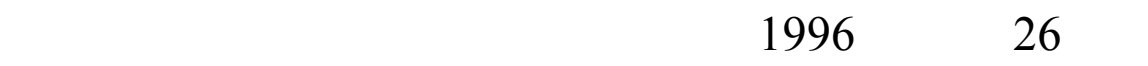
مخصصة للعسكريين الامريكيون في (ميناء الخبر) للسعودي على فيلهل

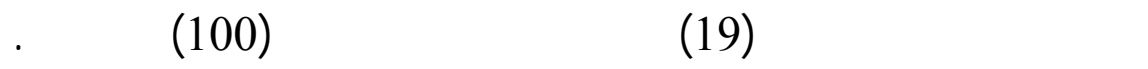

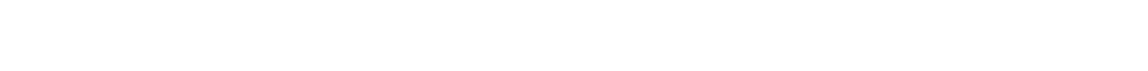

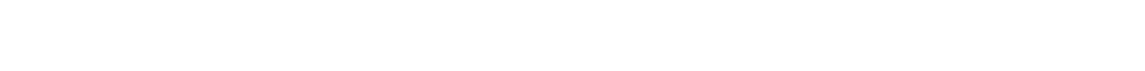

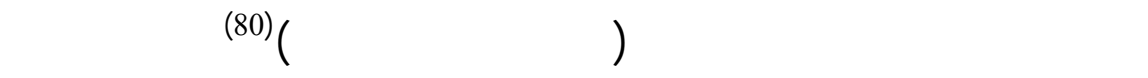

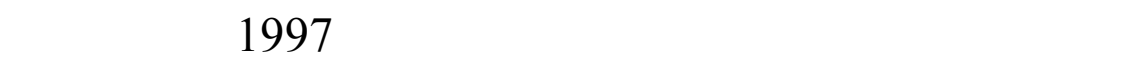

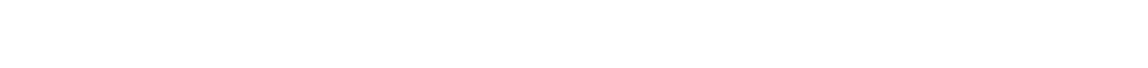
في ظظل الادارة الايرانية الجيدة. 


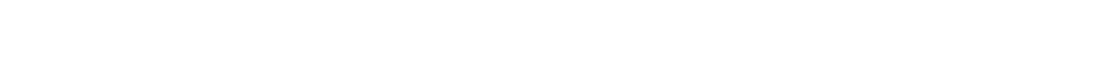

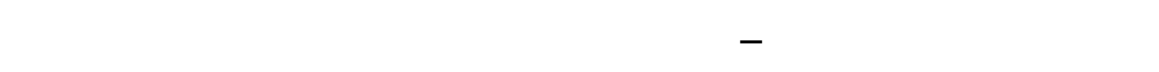

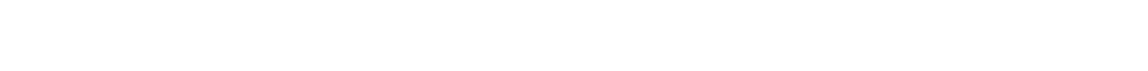

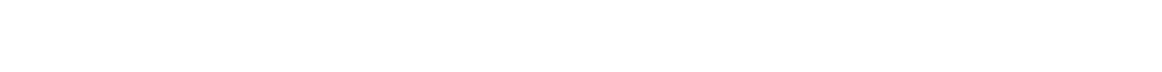

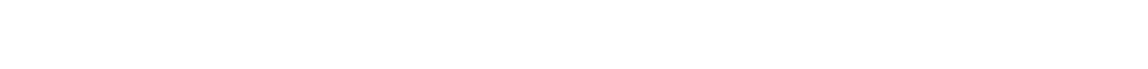

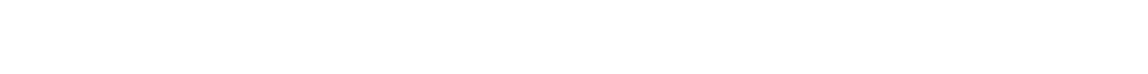

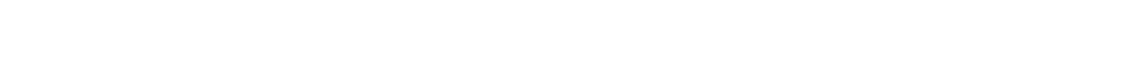

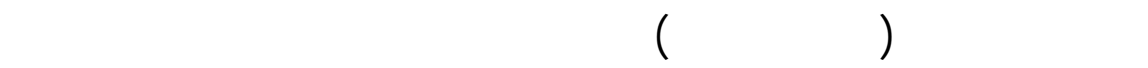

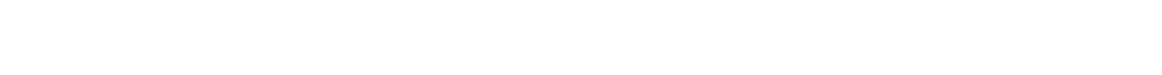

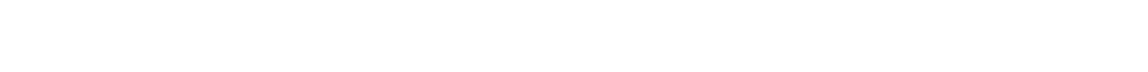

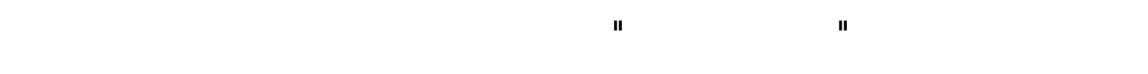

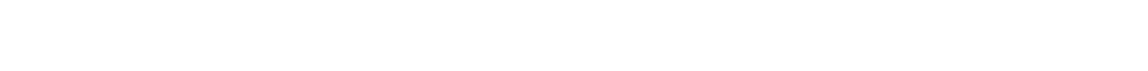

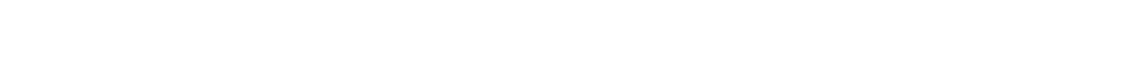

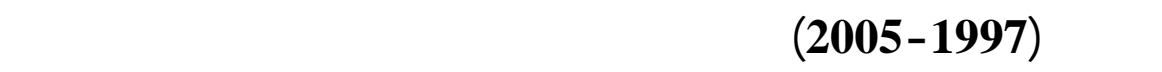

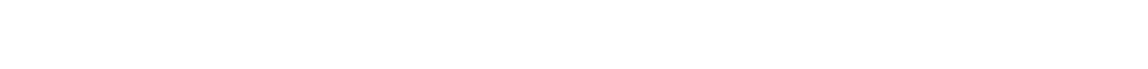

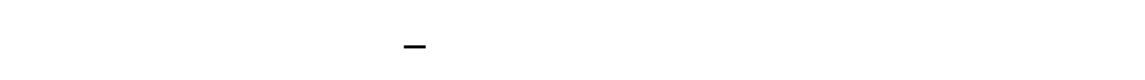

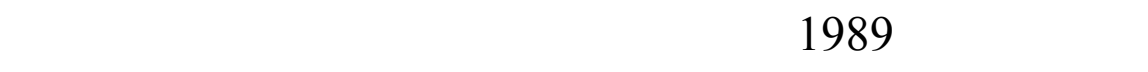

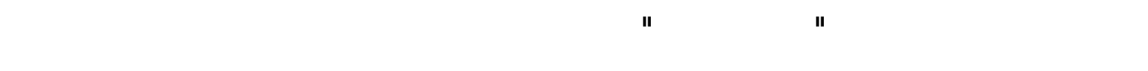

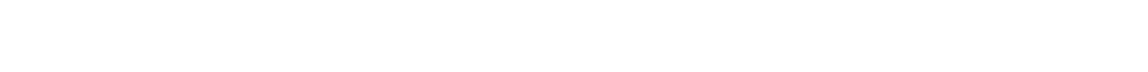

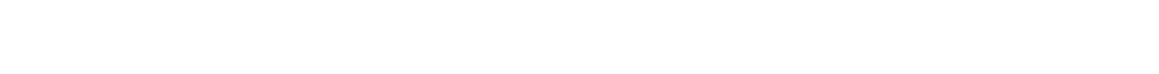

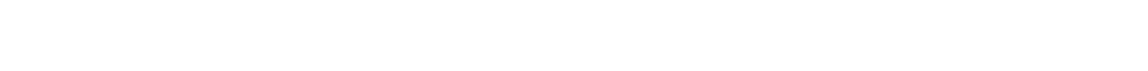

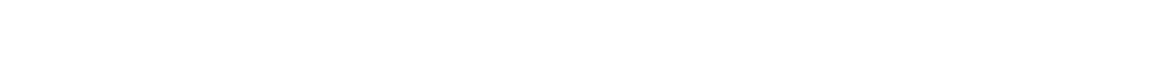




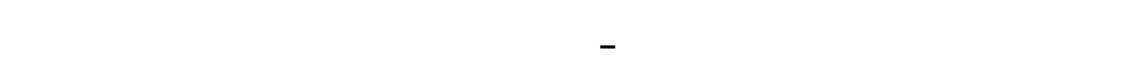

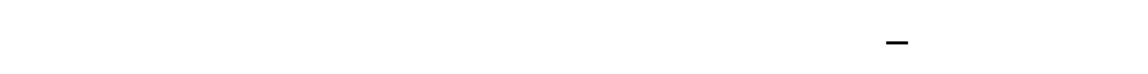

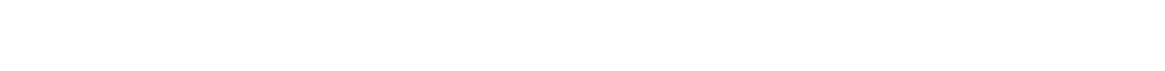

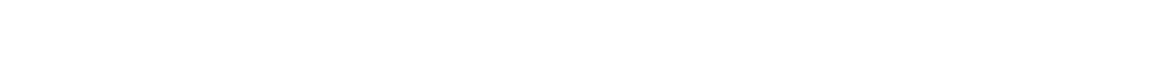

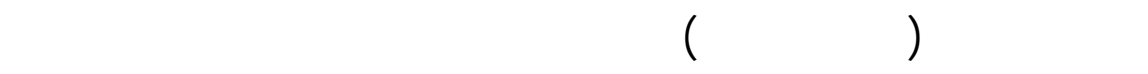

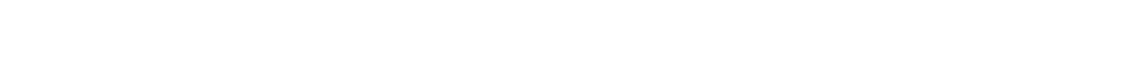
التطيعة والمولجهة مع دول الجوار وخصوص أ دول مجل س التع اون التهل الخليجي (81).

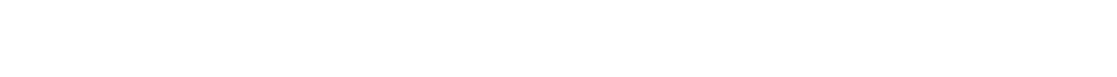

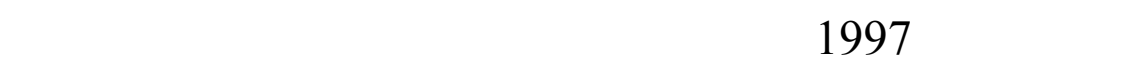

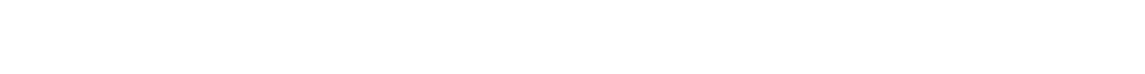

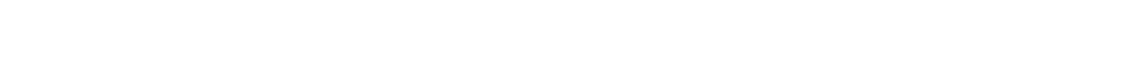

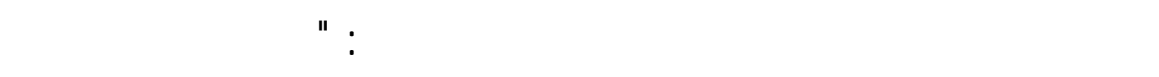

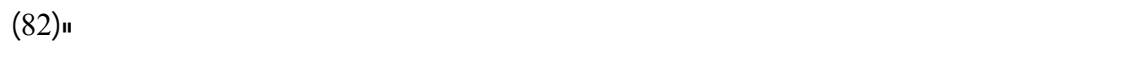

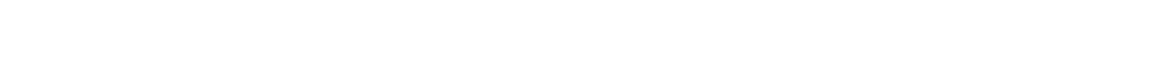

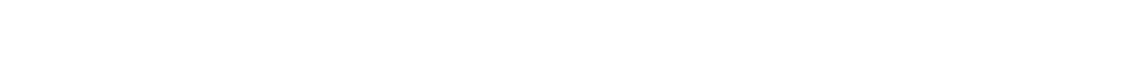

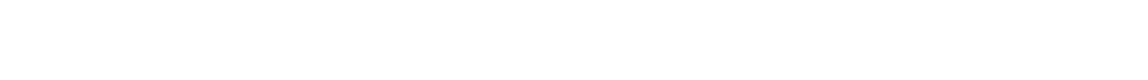

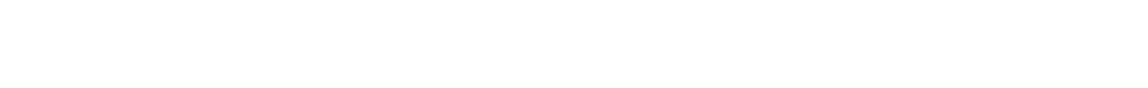

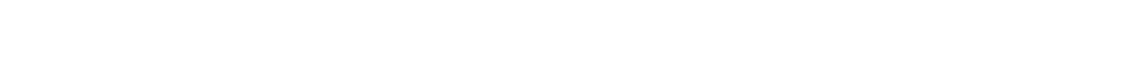

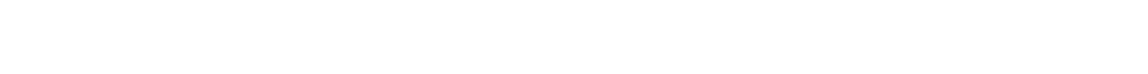

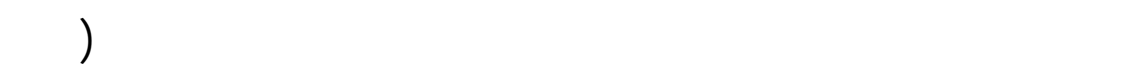

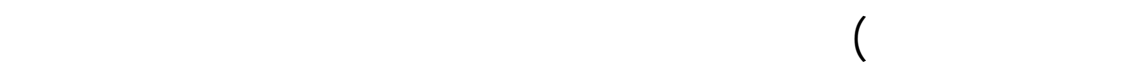

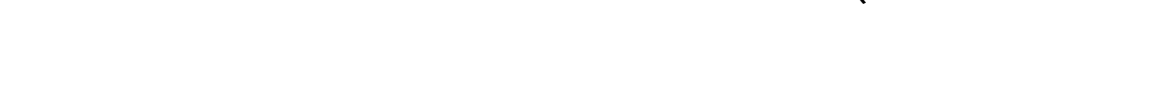




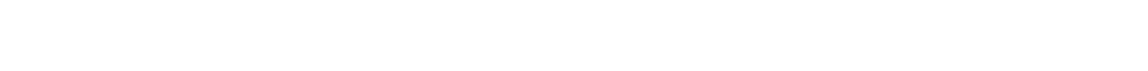

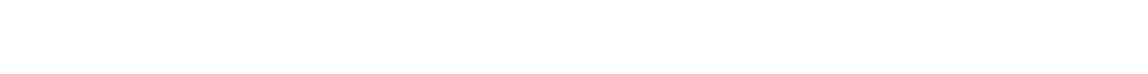

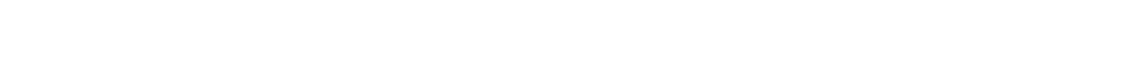

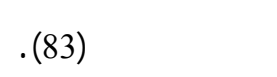

بالمقابل فأن المملكة العربية اللسعودية وجدت بأن علافاتها مع لي ـران

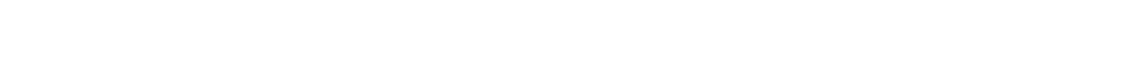

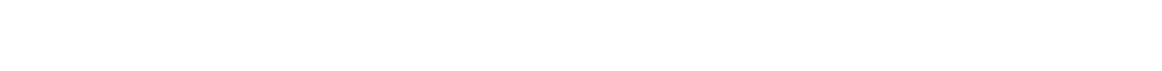
بدورمسيعكس بطبيعة الحل تمحسناً في علاقاتها الاقتصادية مع اليران في مجل النط والتجارة (84).

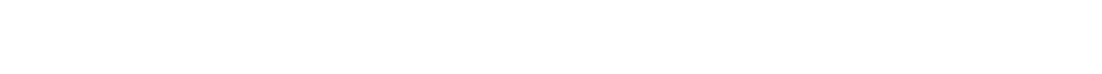

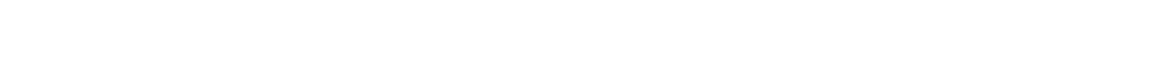

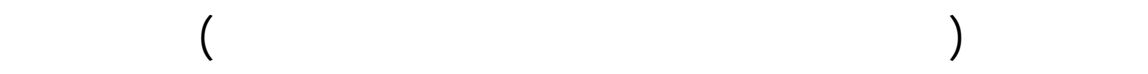

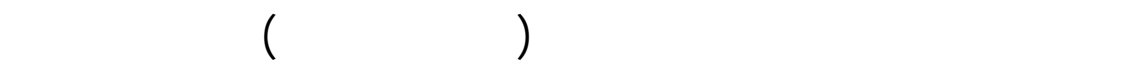

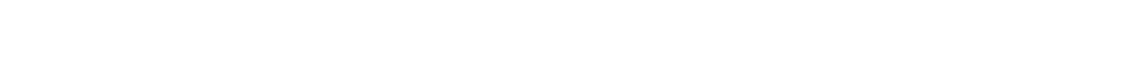

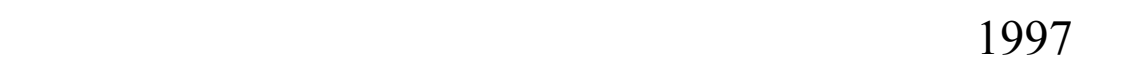

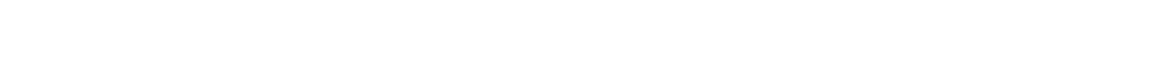
طهران في كانون الاول 1997، حيث أزيلت فيها المحانير وبدأت صفحة

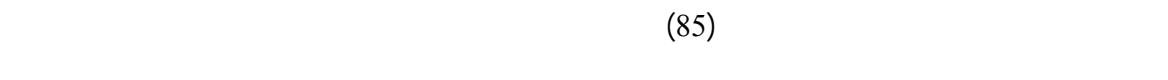

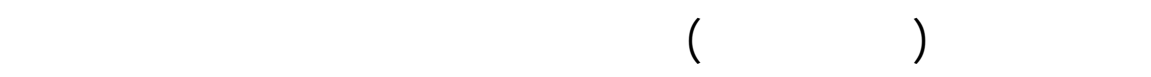

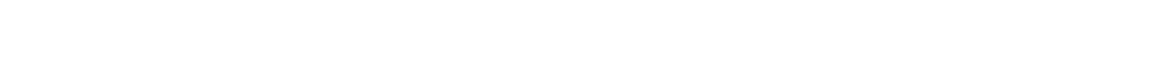

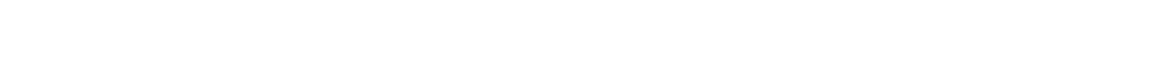

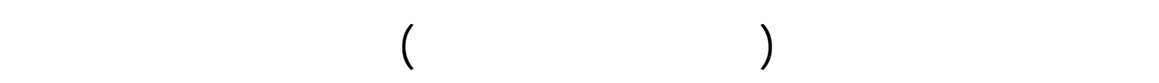




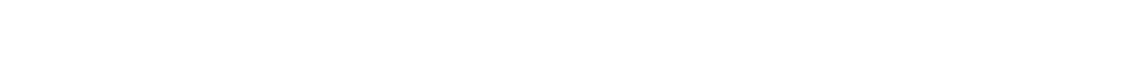
دول الخلبج العربي، بل ومع باقي بلدان العالم الإلامي (86).

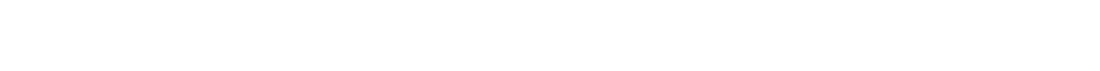

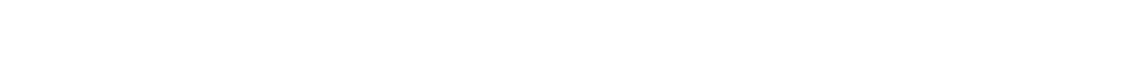

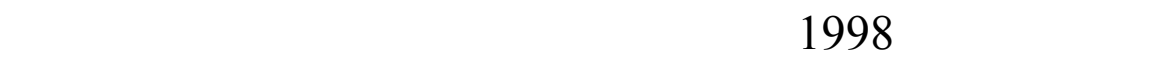
1998 -2002 للتعاون في المجالات الاقتصاية والفنية والعلمية والقفاية

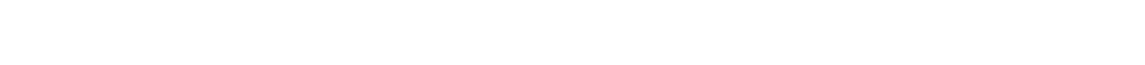

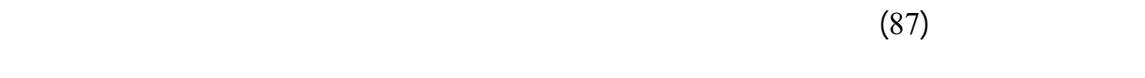

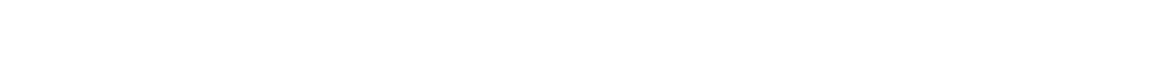
شهري اليار وحزيران 1998 (88). ولتظيم ومتابعة تنلك الافقاقت تشكلت لجنة اقتصاديةسعودية - ايرانية

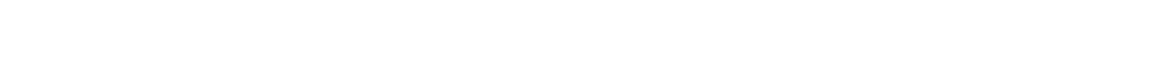

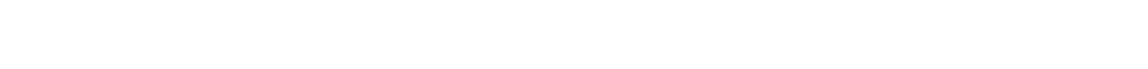

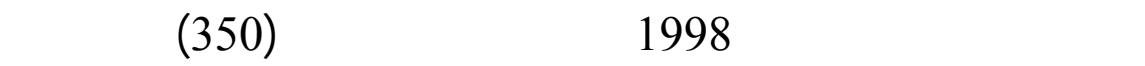

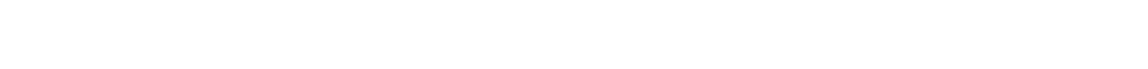

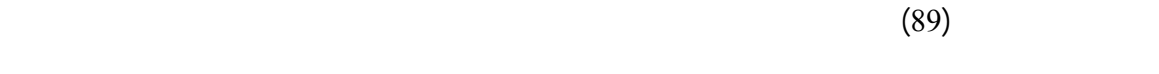
(90) وجاءت زيارة الرئيس الايرلني محمد خاتمي اللى الري اض فئ في اذار

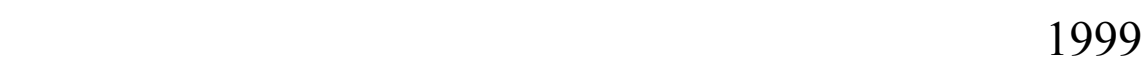
ختلمي مشترك تضضمن ع عة لمور منها:

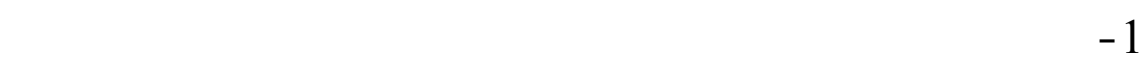

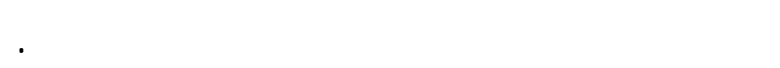




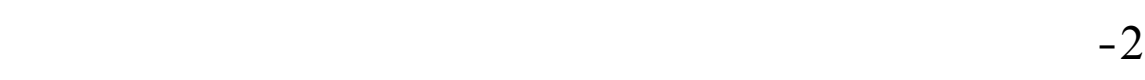

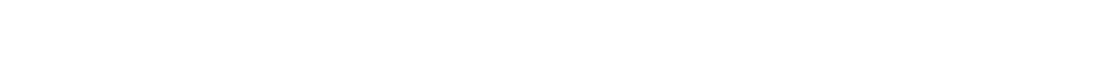

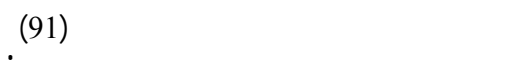

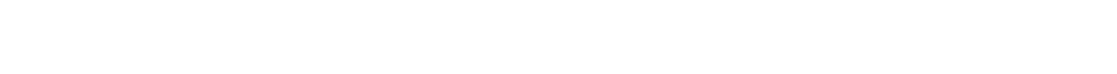

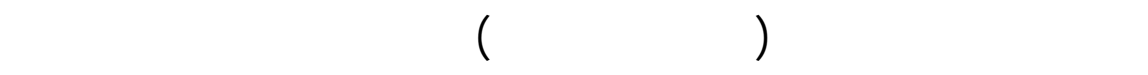

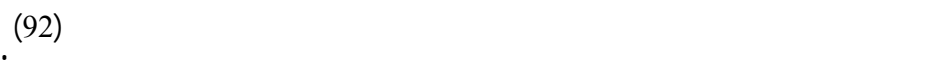

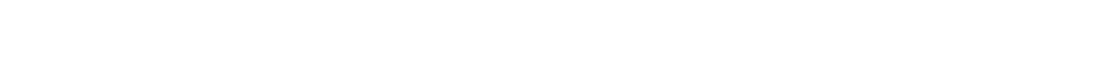

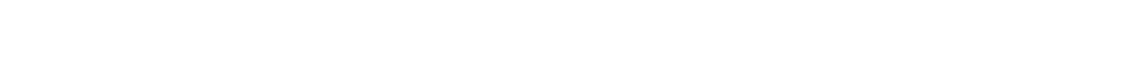

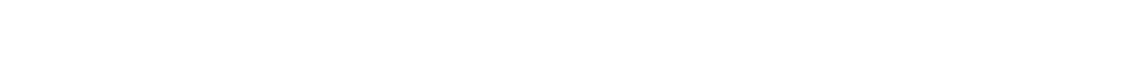

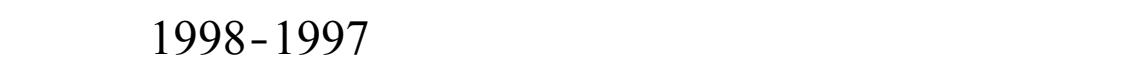

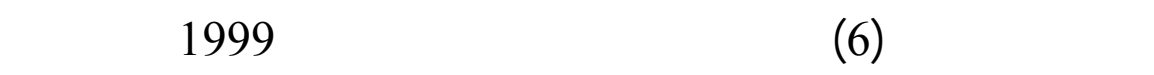

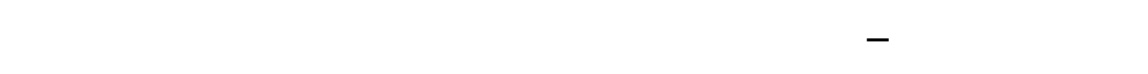

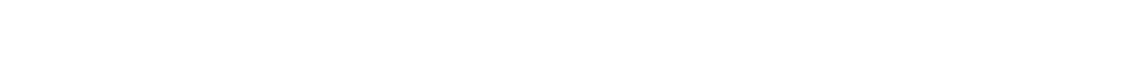

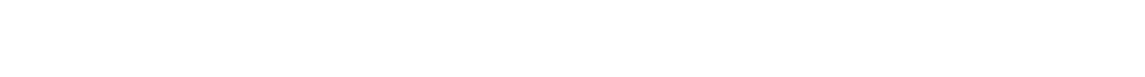

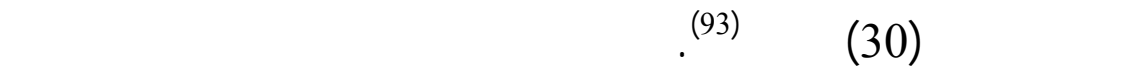

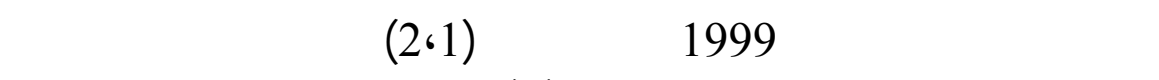

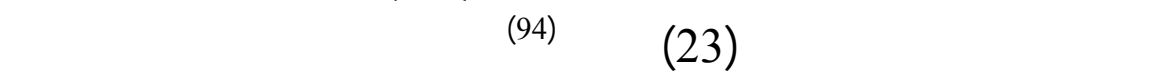

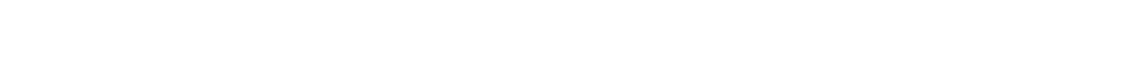

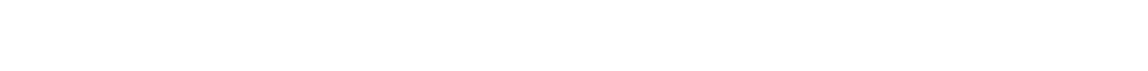

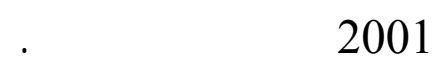




\section{الاتفاقية الأمنية الايرانية السعودية 2001}

$$
\text { الولاً :- دوافعها }
$$

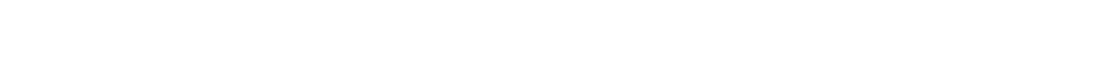

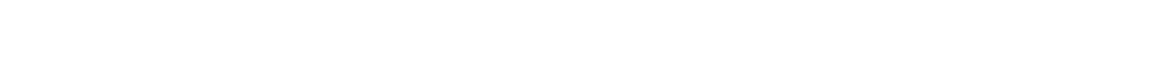

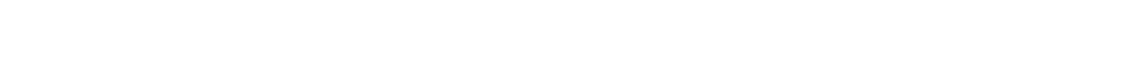

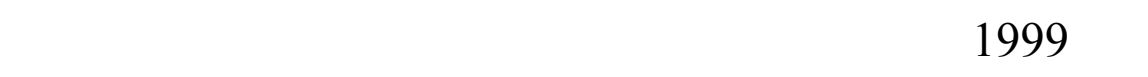

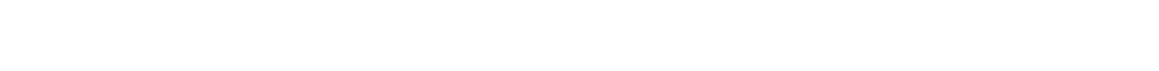

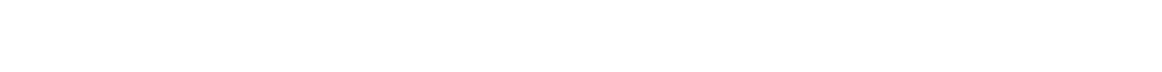

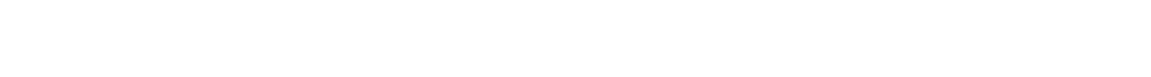

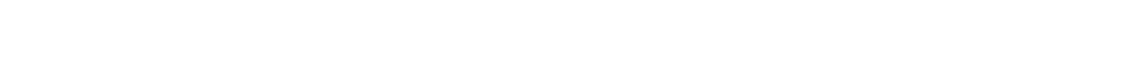

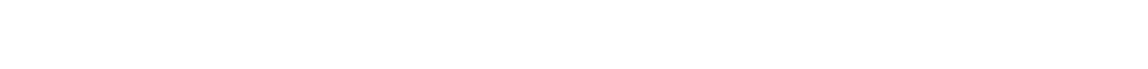

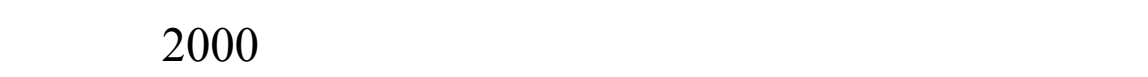

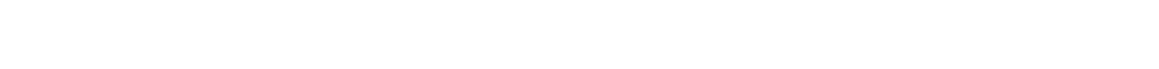

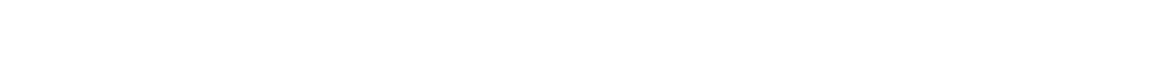

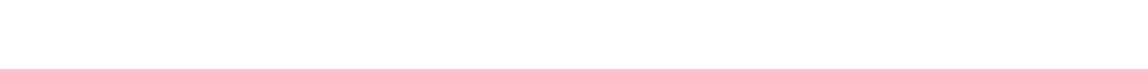

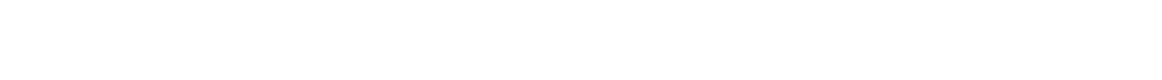

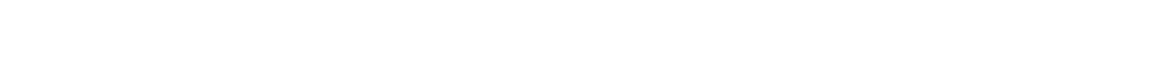

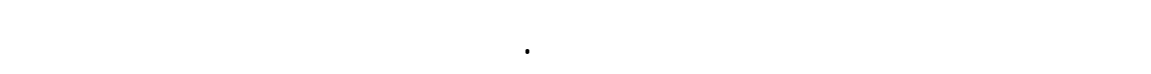

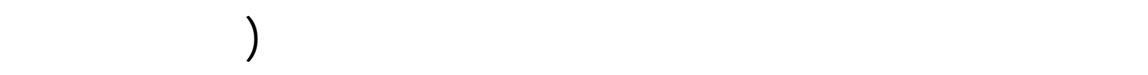

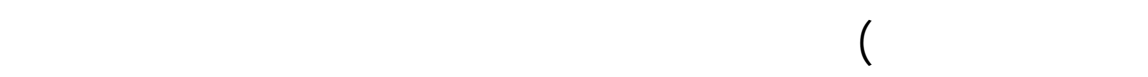

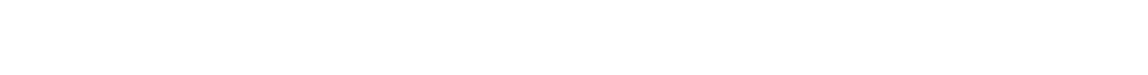

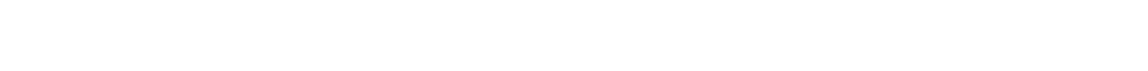




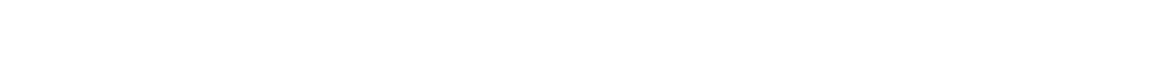

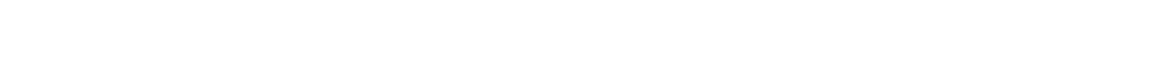

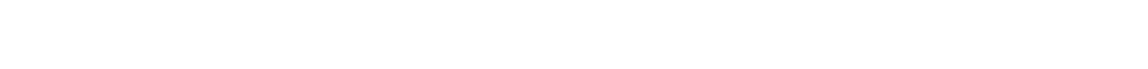

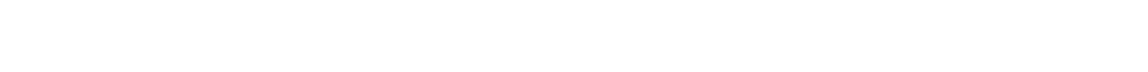

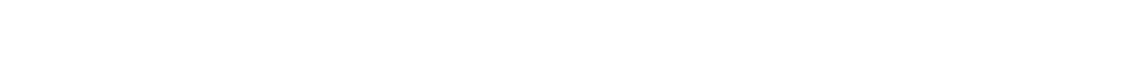

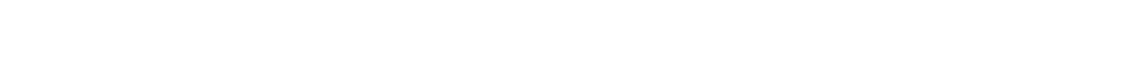

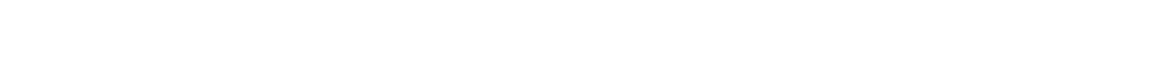

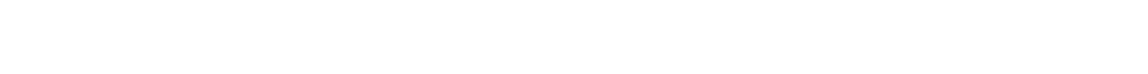

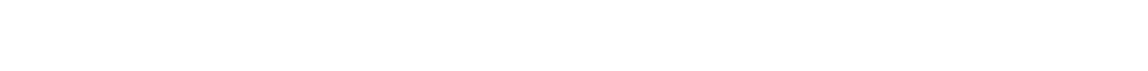

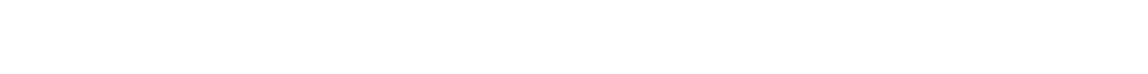
الايرانية (95.

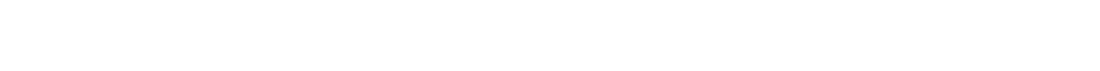

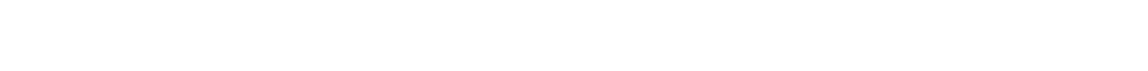

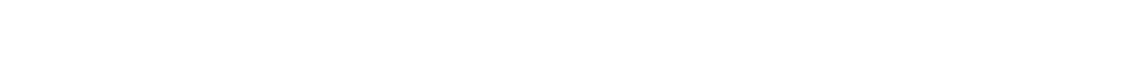

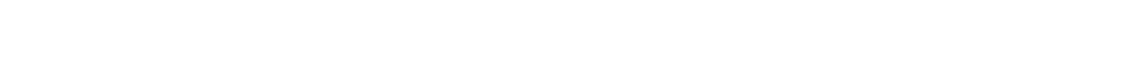

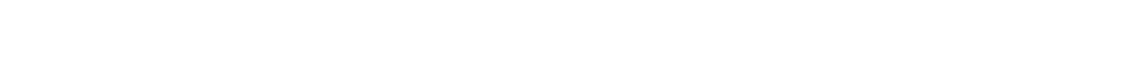

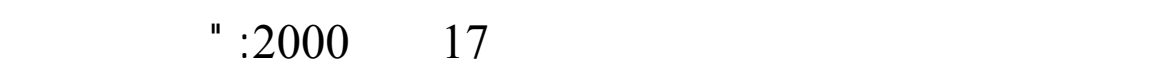

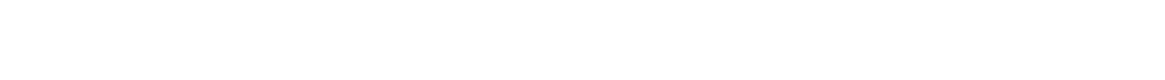

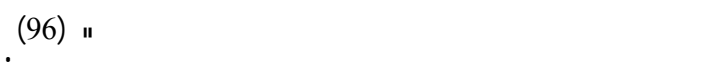

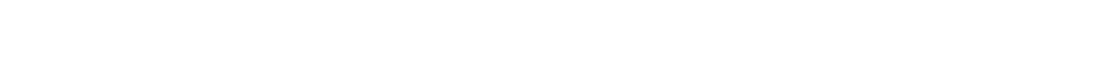

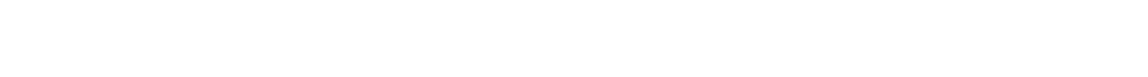

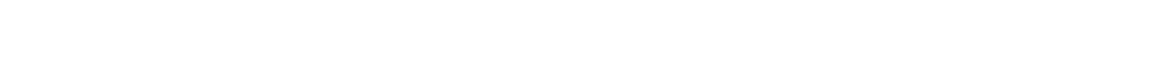
غير معقول، وعلى ذك فأن مشاركة ليران في لية ترتيبيت لمنية المنية مستقبلية 
هو امر حتهي لامفرمنه، وليران بدوها تدرك هذا او تروج له، حتى ان

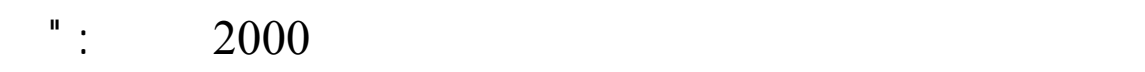

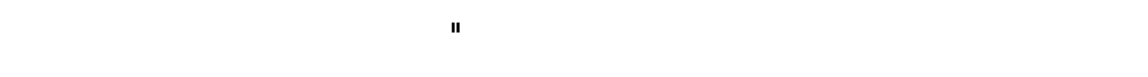

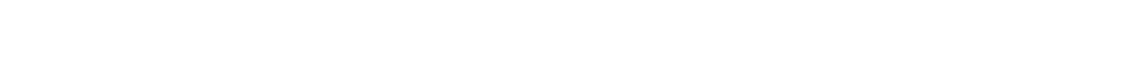

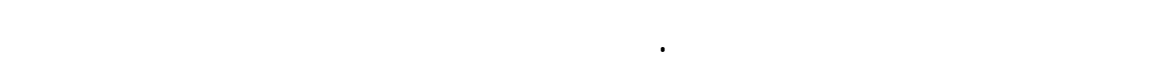

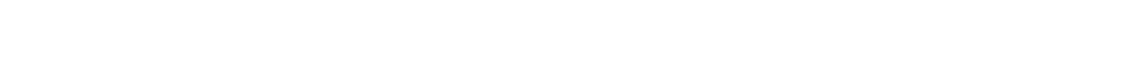

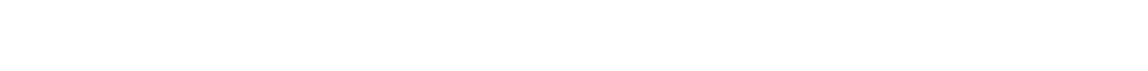

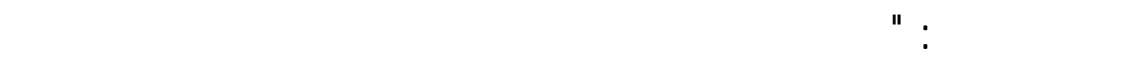

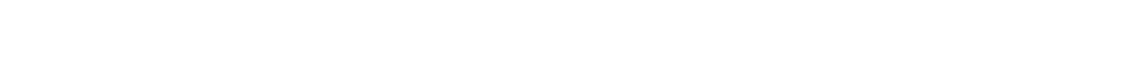
المعالفة مع ليران" (97).

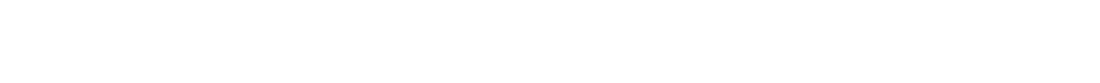

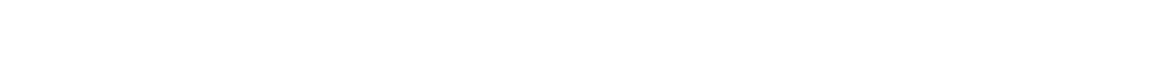

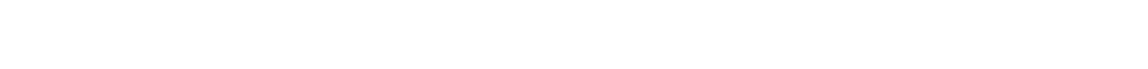

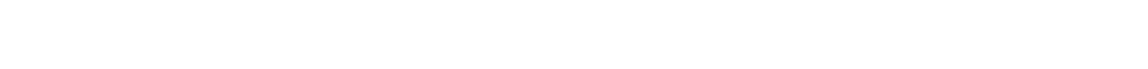

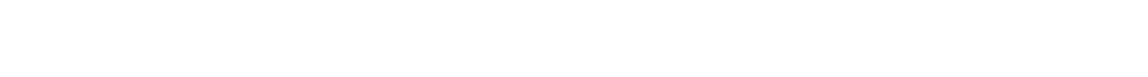

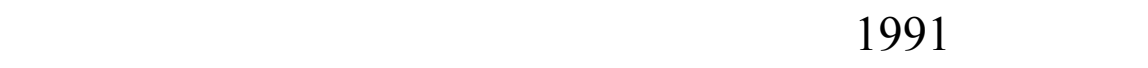

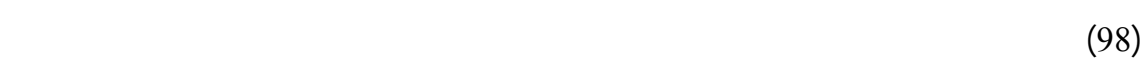

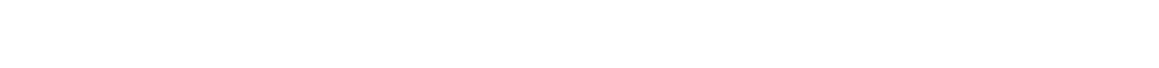
ايران (99).

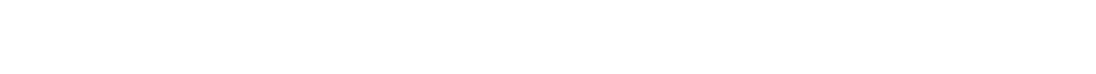

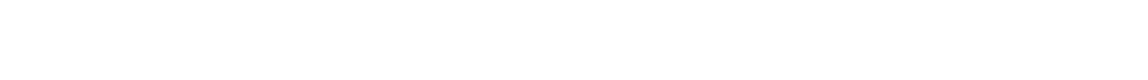

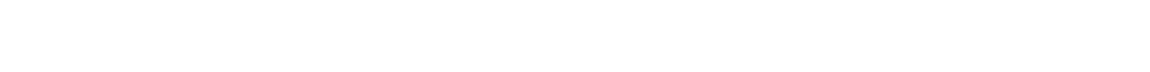
بالطمئنان تجله مخاوفهر من الوجود الامريكي في المطقة، وقد تلك دت 
هذه الرؤية في ظلل التهلمات ولشطن المتكررة لطه -ران بـ الوقوف وراء المناء

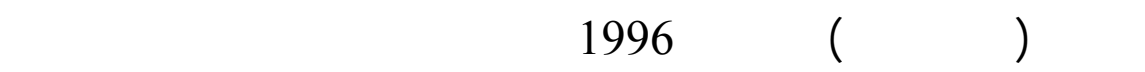

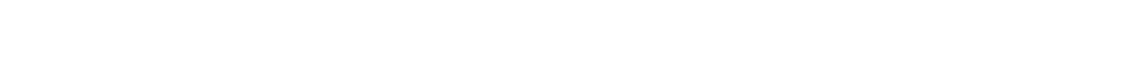

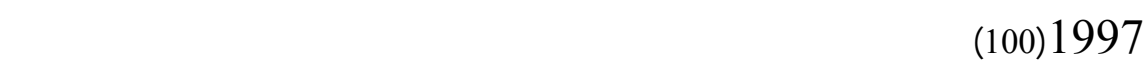

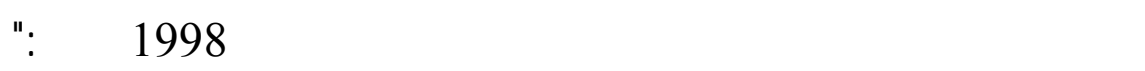

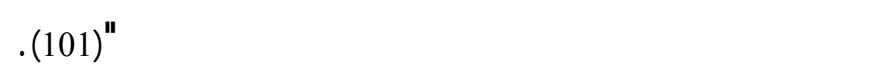

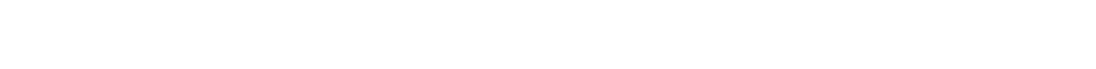

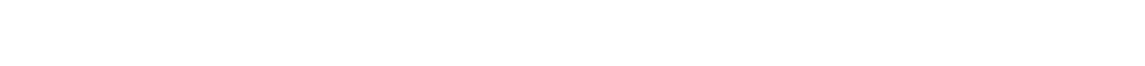

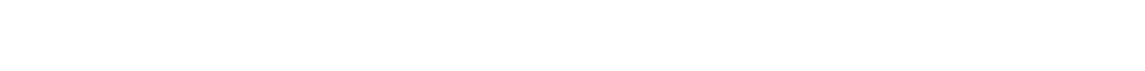

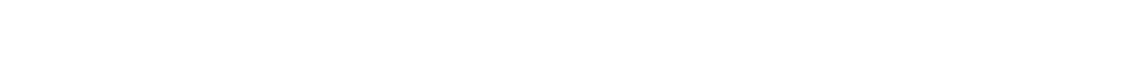

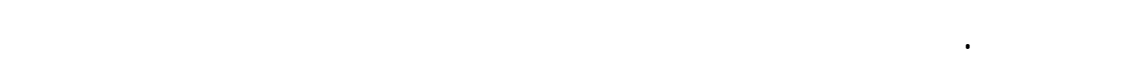

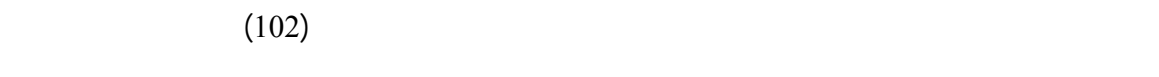

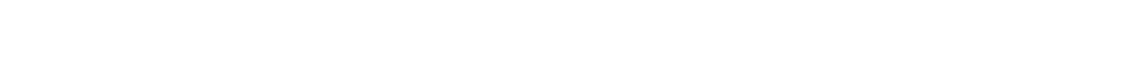

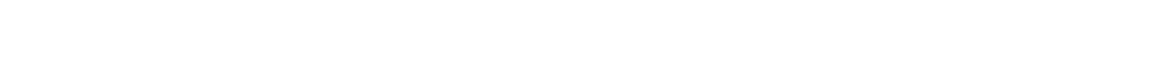

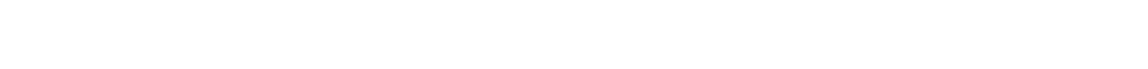

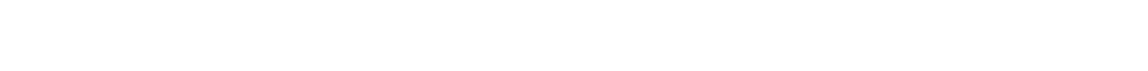

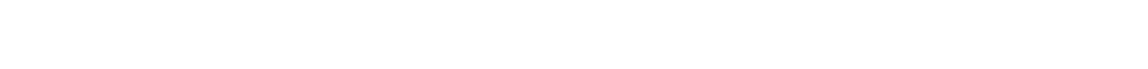

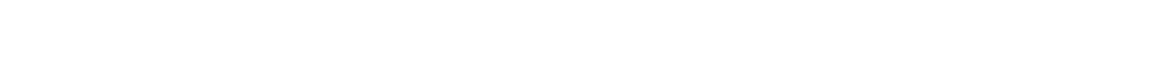

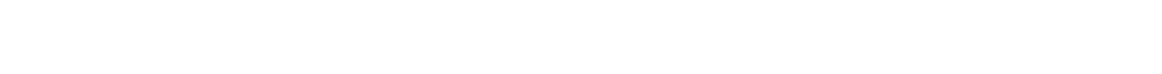

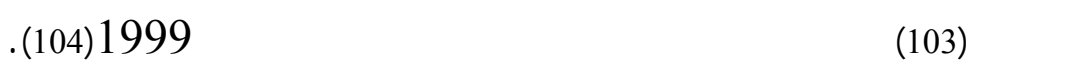

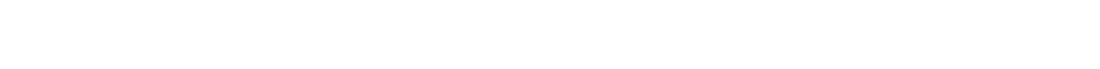

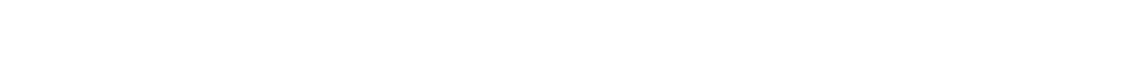

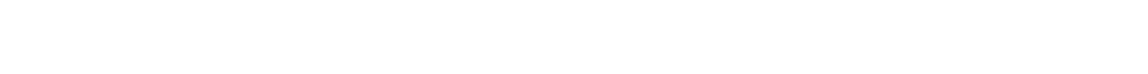


وجود نوع من انواع الاختلاف في وجهات الظع بين فين للسعوية ولي -ران،

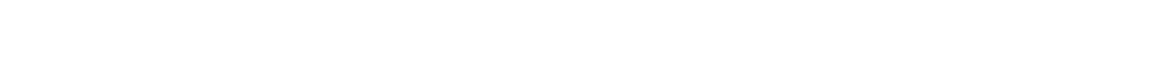

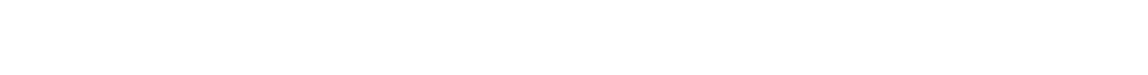

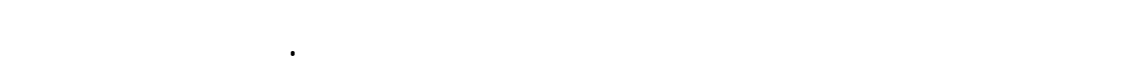

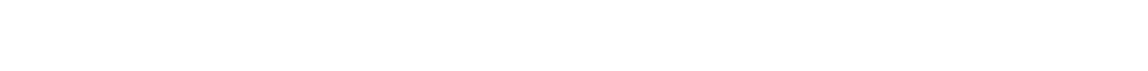

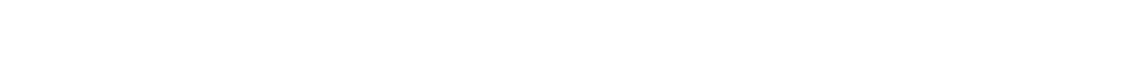

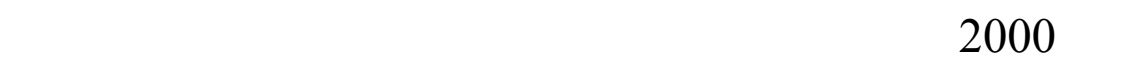

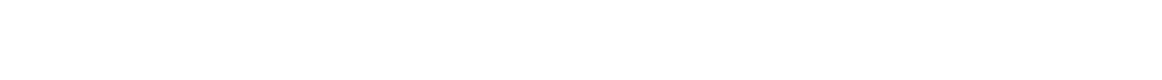

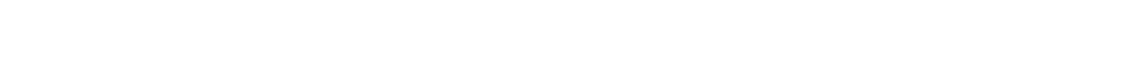

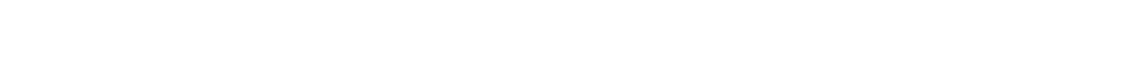

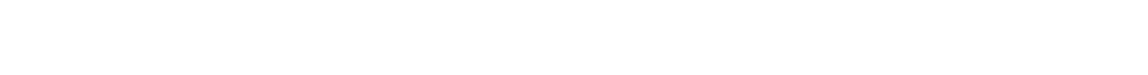

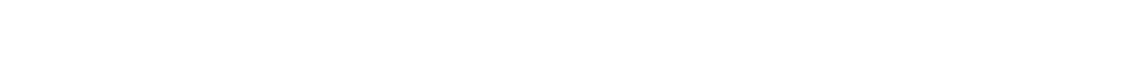
اللسعودي في الفتاح مجلس الوزارة الخليجي في جلة في في 19 نيسان 2000

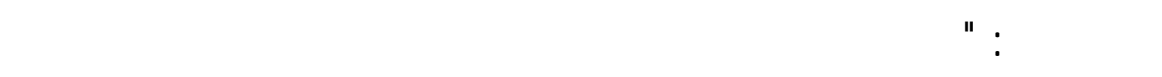

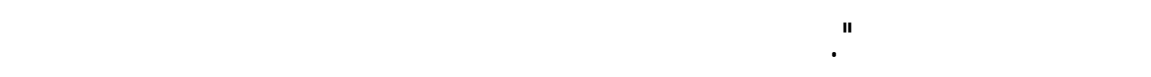

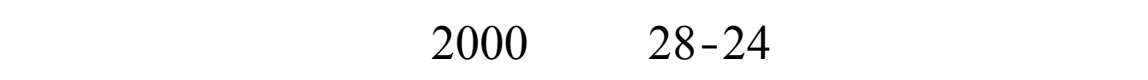

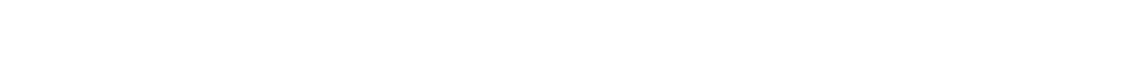

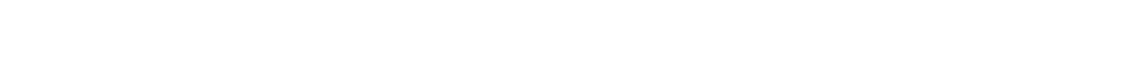

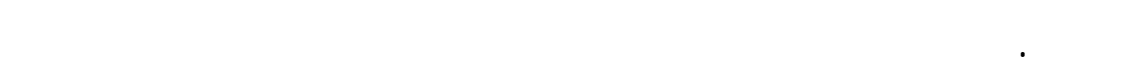

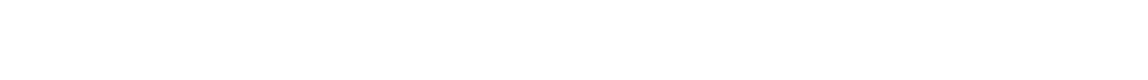

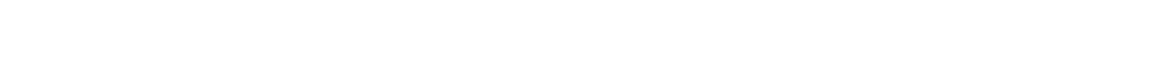

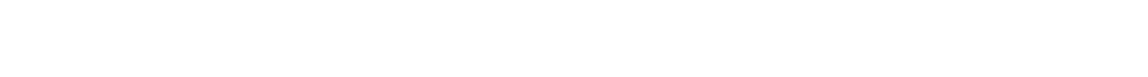
طبيعة الظروف الدولية (105). 
وفي زيارة ثانية لوزير الدفاع الايراني اللى الرياض في اي ار 2000

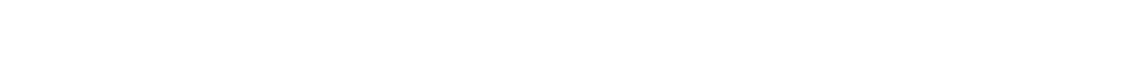

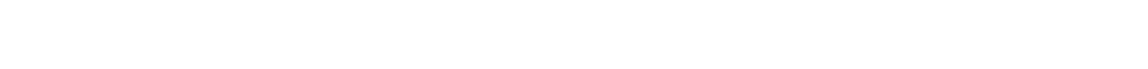

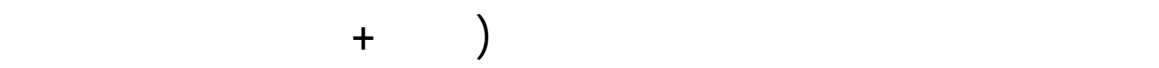

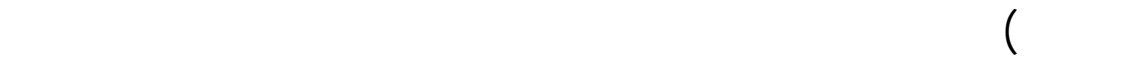

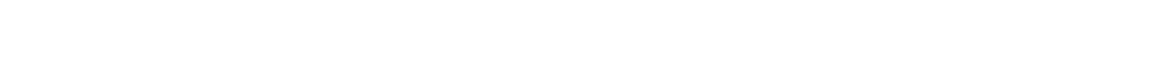

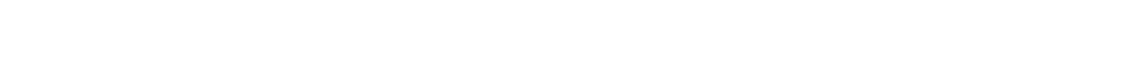

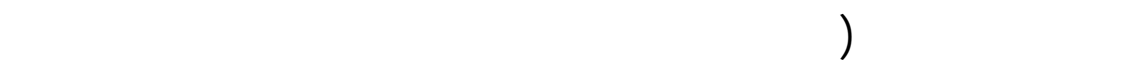

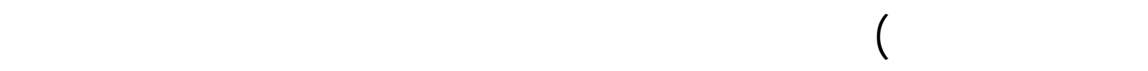

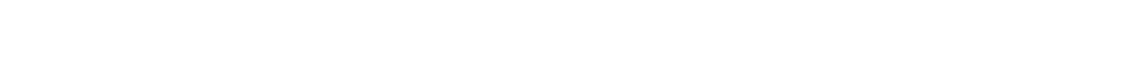

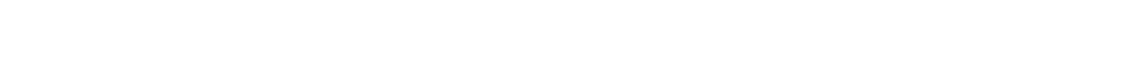

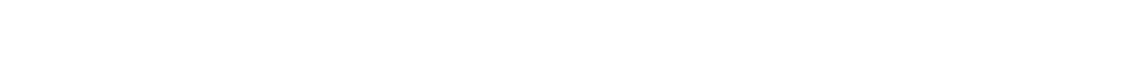

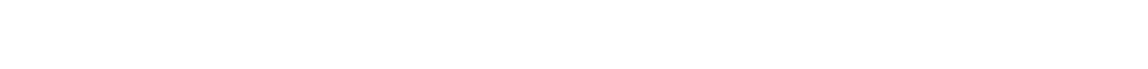

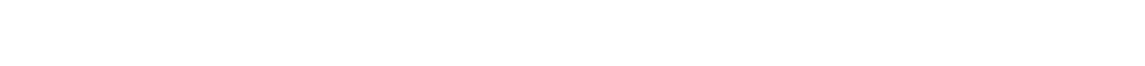

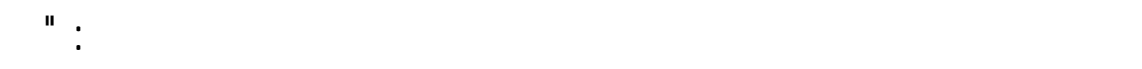

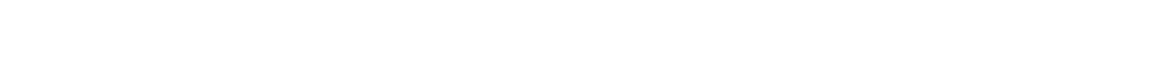

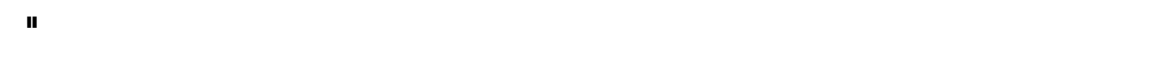

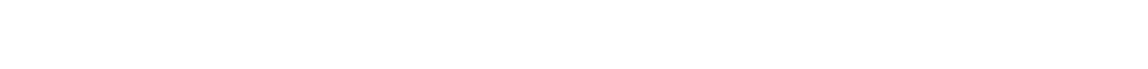

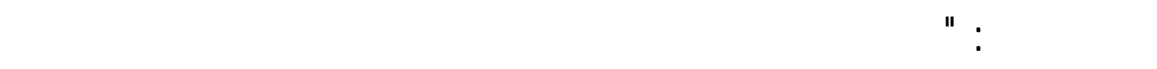

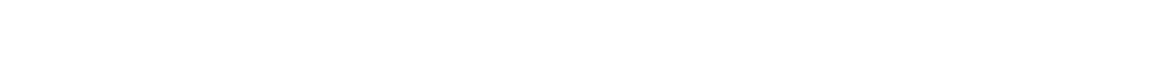

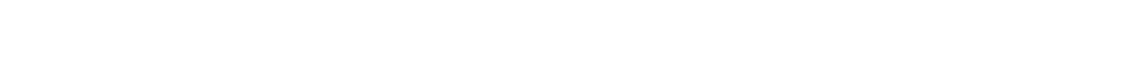

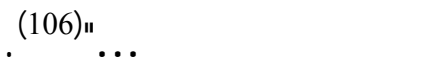


ثلنياً: - محاورها الاساسية

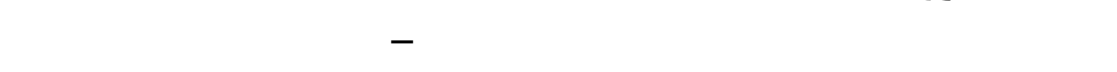

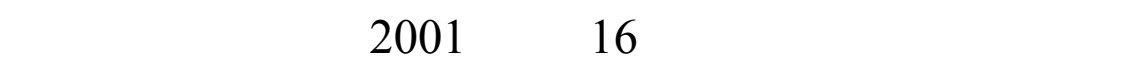

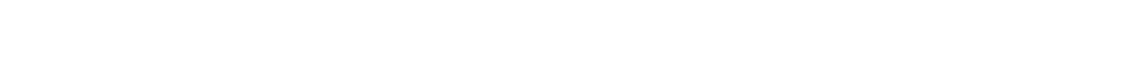

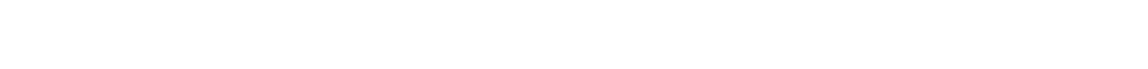

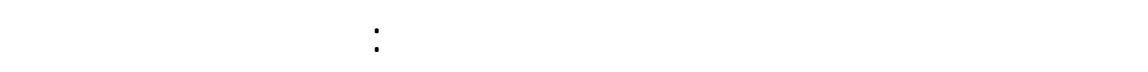

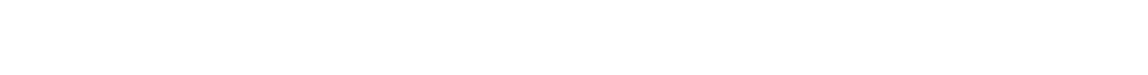

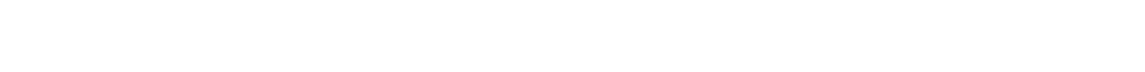

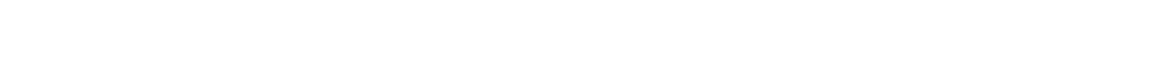

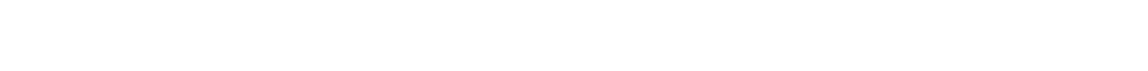
على ما يأتي:

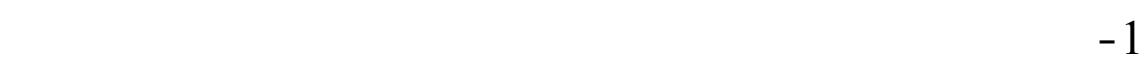

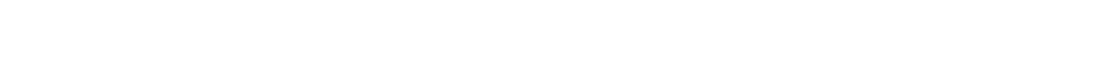
هذه الاظطار.

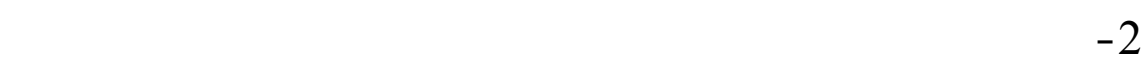

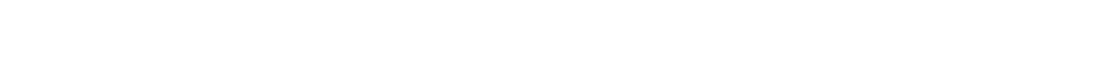

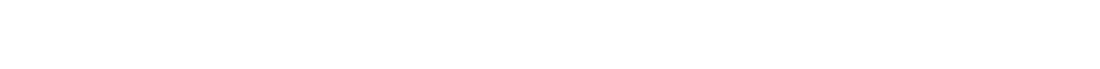
ومكافحة جرائم تهريب الإلحة والبضائع وتهريب الاث الثي لار والت _راث القعالف.

3 - التعاون في مجل الاقاذ البحري ، والتسل غير المشروع.

4 - التعاون في مجل مكلفحة المخدرات (تجارةً ولستهلانكاً).

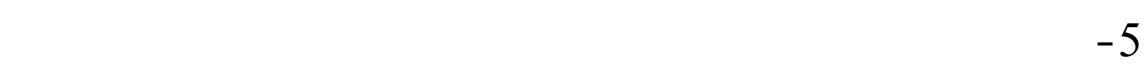
والمعلوملت الامنية. 
6 - منع الهجرة غير القانونية ، وفرض الرقابة عل ف الح ـدود والمي له

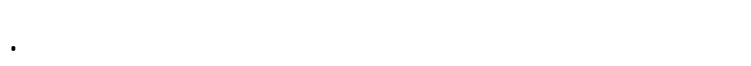

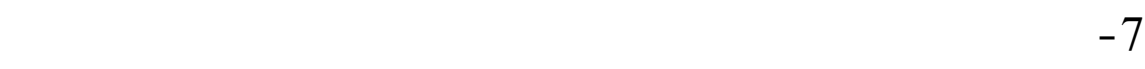

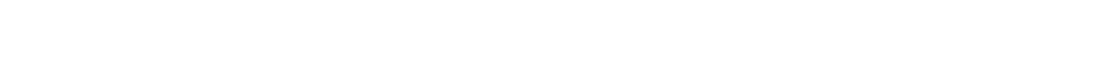

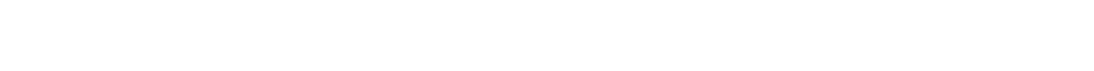

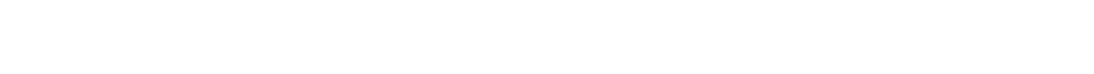

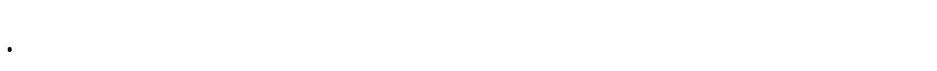
8 - زيادة اقلمة معارض تجارية وصناعية بين البلدين .

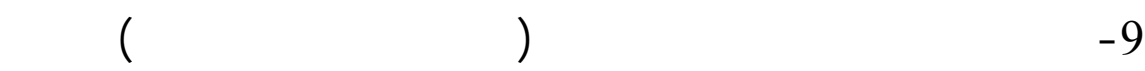

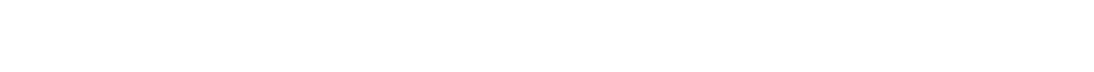

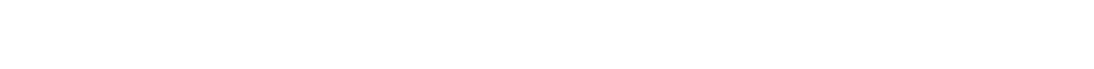
شأنه الاضرار بالعلاقلت الاقتصادية المتبادلة. 10 - تحجيم نشطلت الاضرار بالمعارف المضنة في كلا البلدين المنبالن.

\section{شالثأً: - ابعادها}

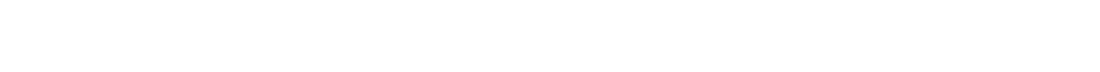

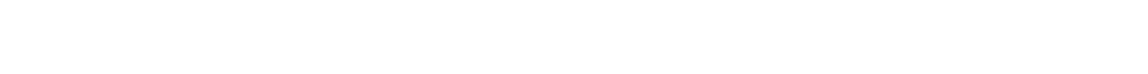

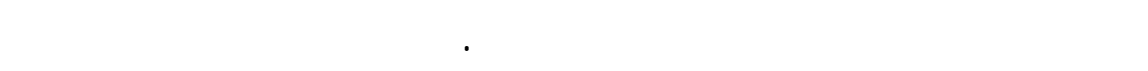

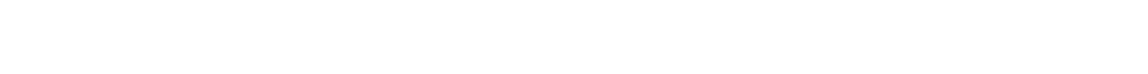

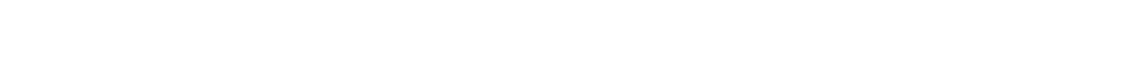

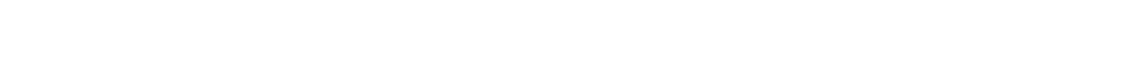

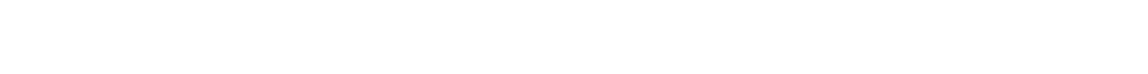

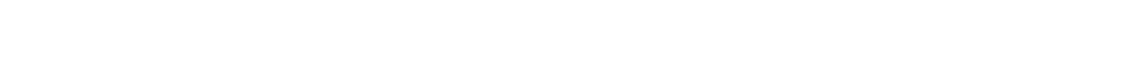




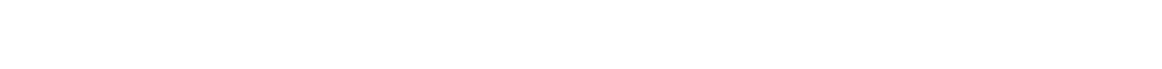

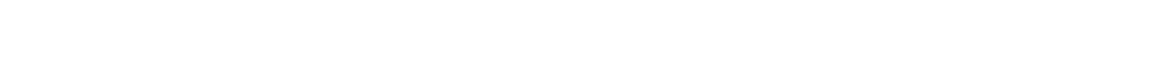

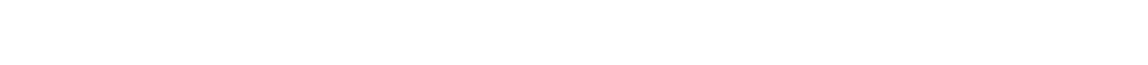
ثلاث لاعالأ اقناعية متباينة الاتجاهات :

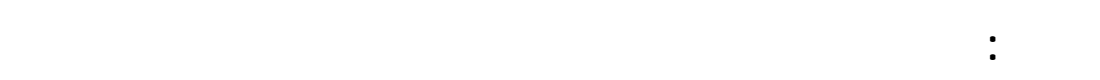
العسكري الاجنبي وخاصة الامريكي في المظقة.

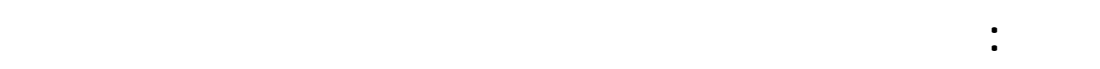
الاسنقرار في الخلبج ، علماً بأن الكويت وسلطنة عمان قد قطعتاش -وطاً معقولاً على هذا الدرب.

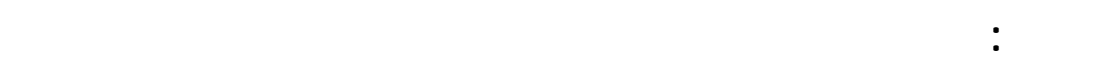

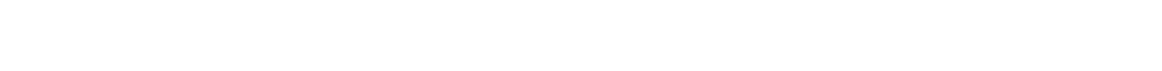

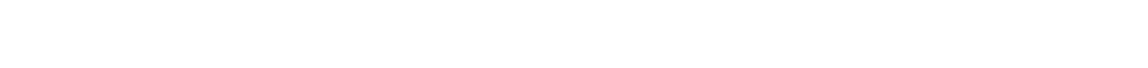

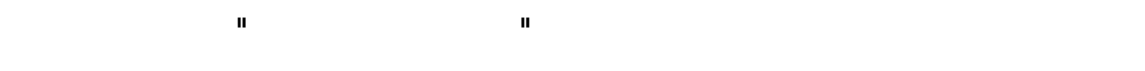

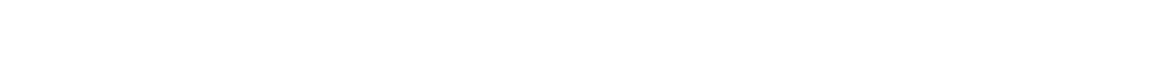

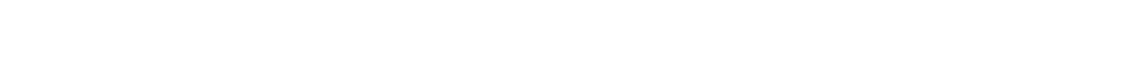

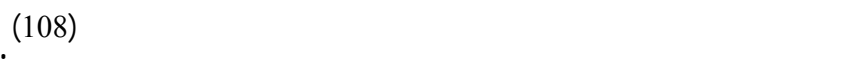

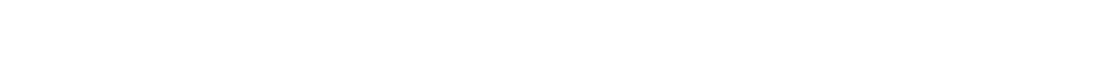

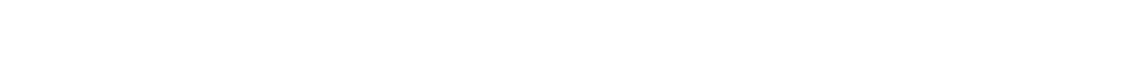

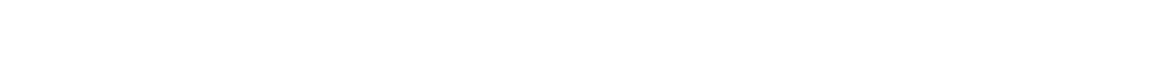

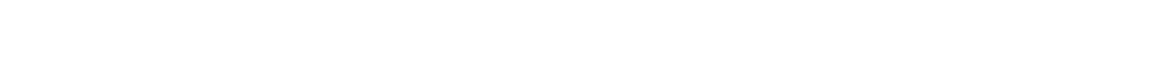

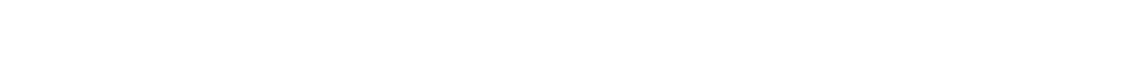

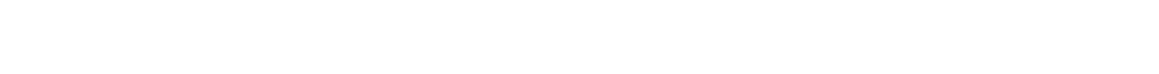
هوت ظرية "الامن القومي العربي" من جراء الاجتياح العراقي للكويت، 


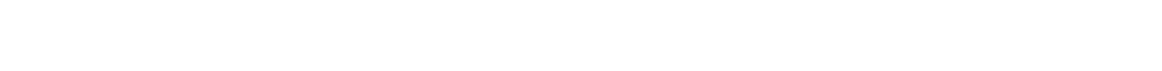

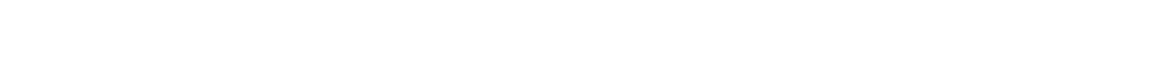

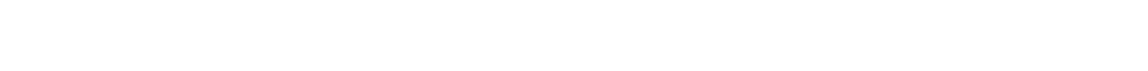

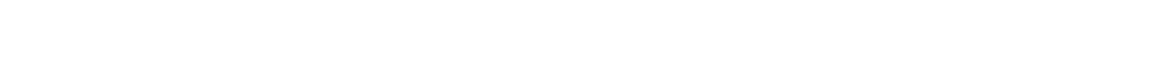

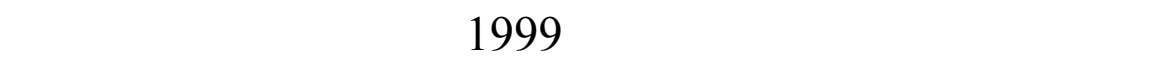

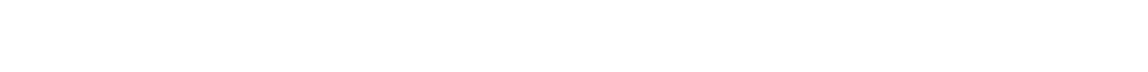

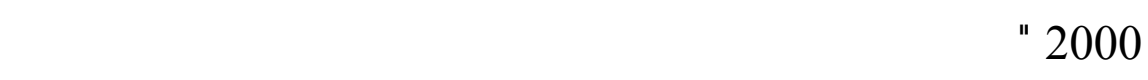

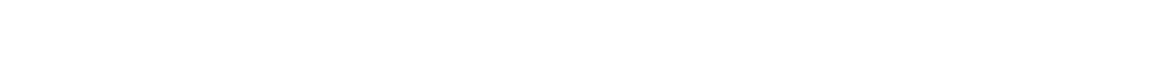

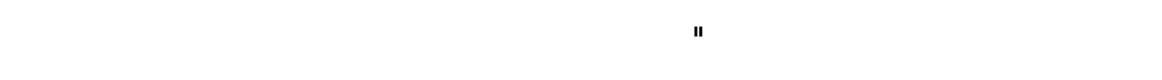

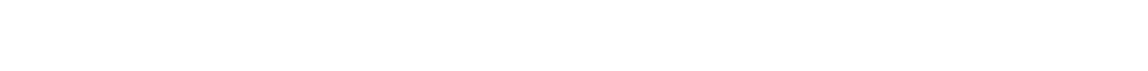

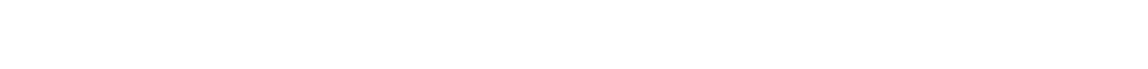

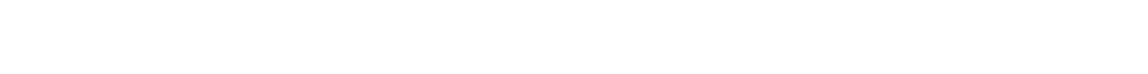

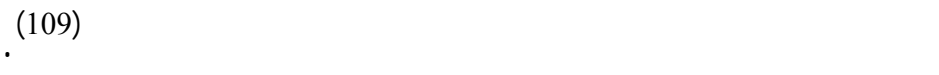

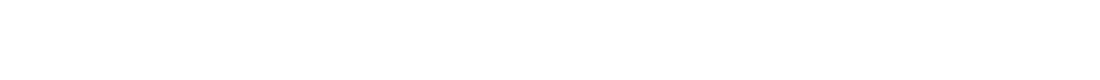

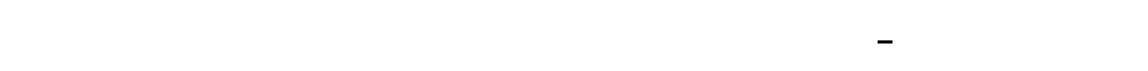

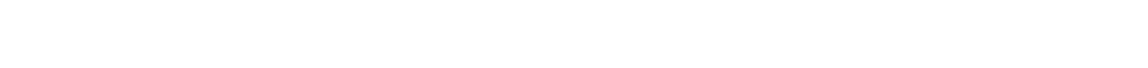

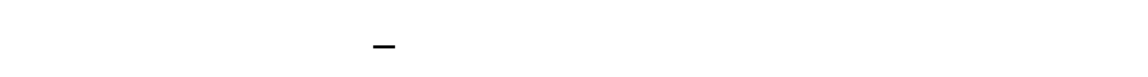

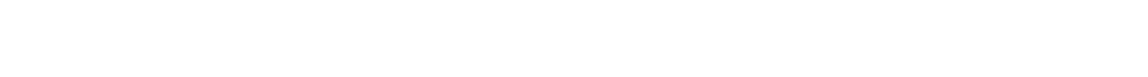

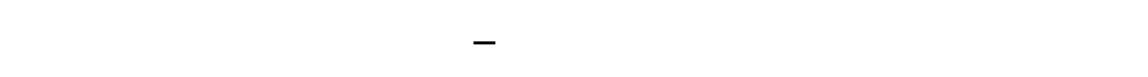

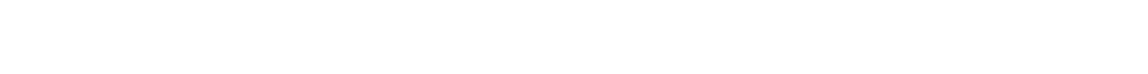

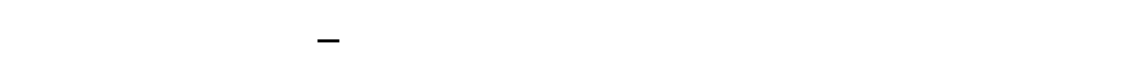

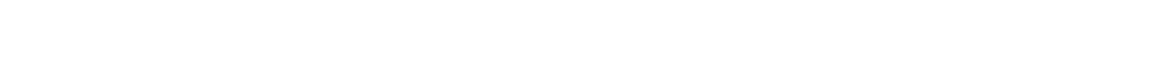

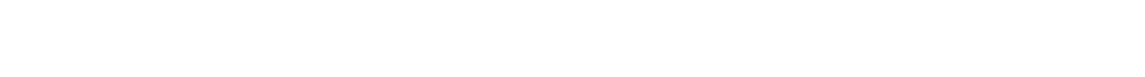


لطهران على القارة الاوريقية في طارسعييها الدؤب لتوسبع وتنويع دوائر

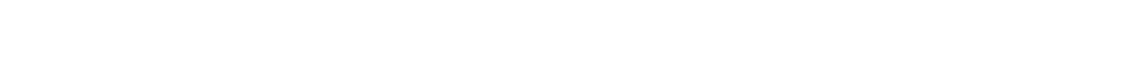

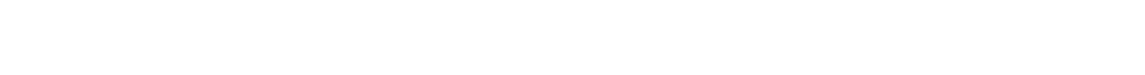

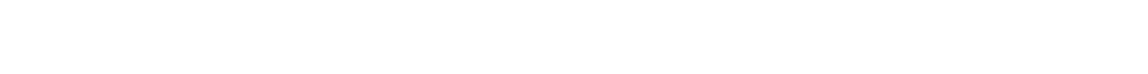

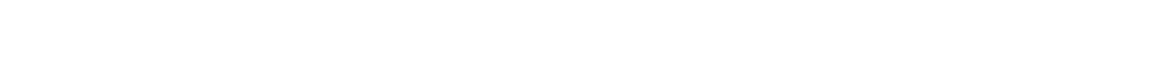

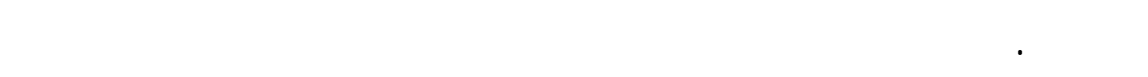

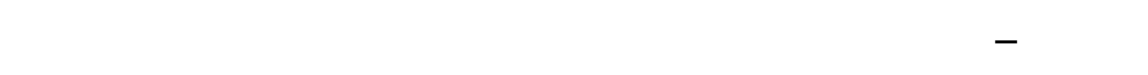

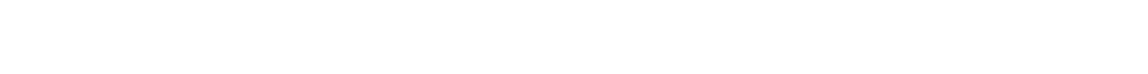

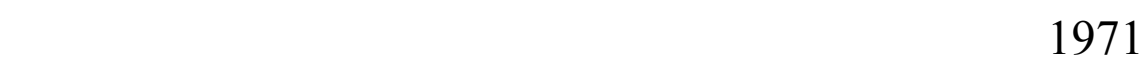

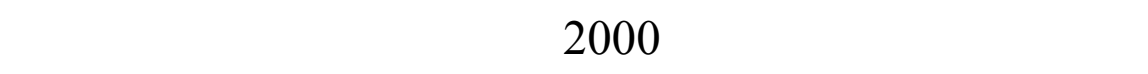

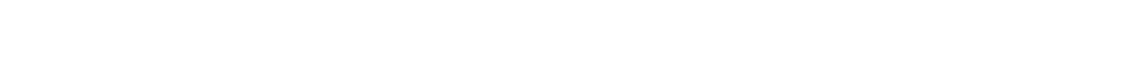

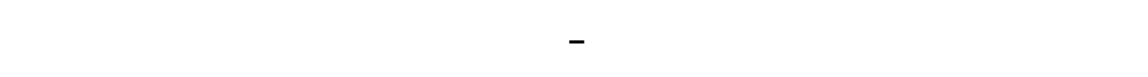

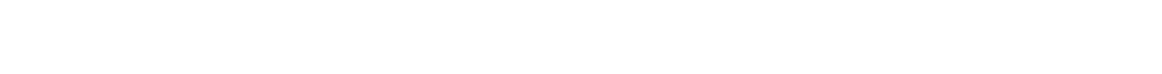

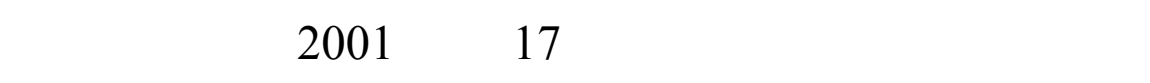

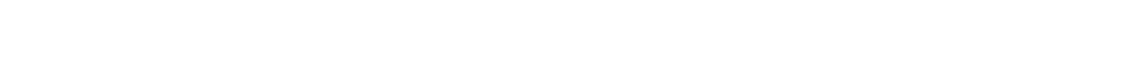

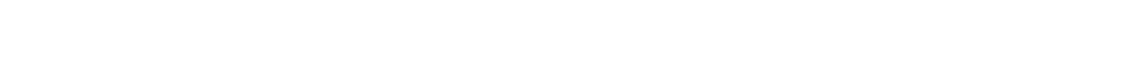

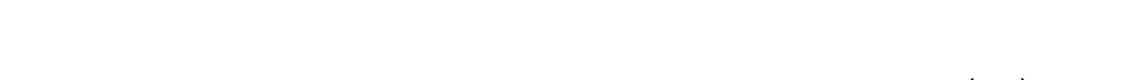

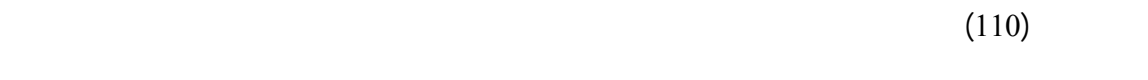

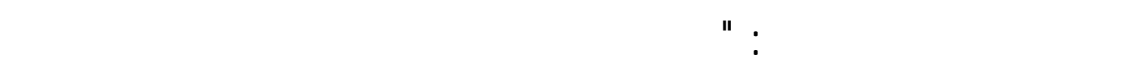

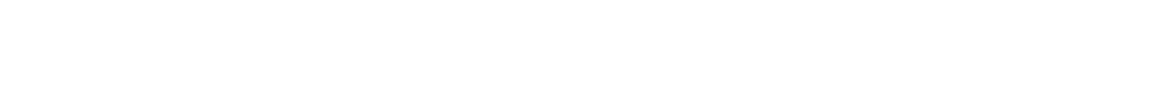
عهطرق الففاوضنا " (111).

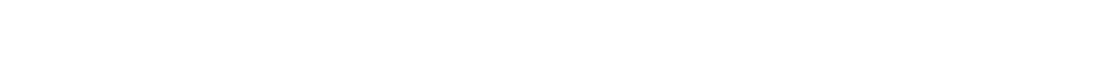
الوجود العسكري الاجنب، وخاصة الامريكي في الخلبج، فقدر ما كالنت 


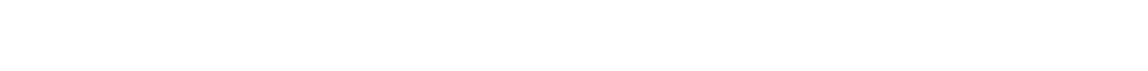

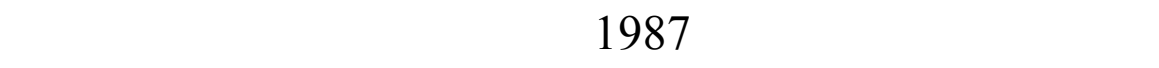

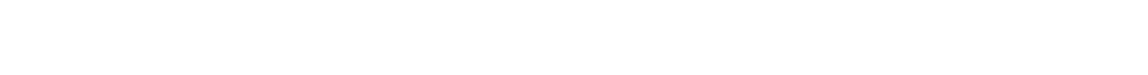

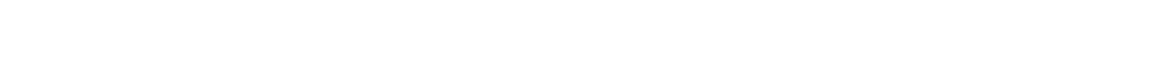

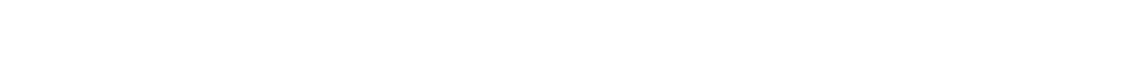

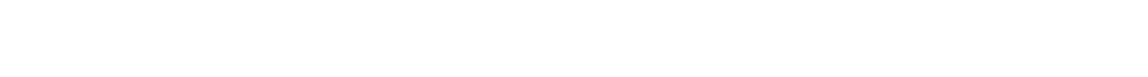

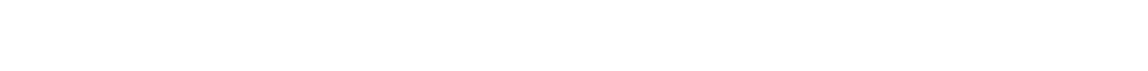

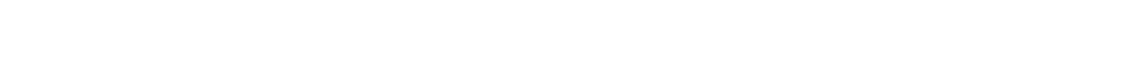

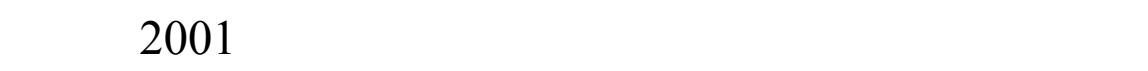

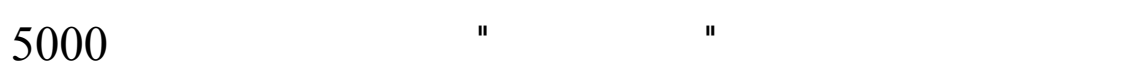

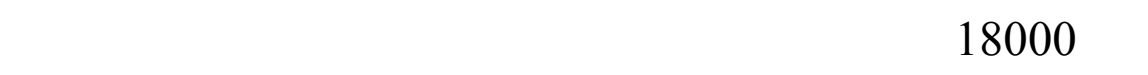

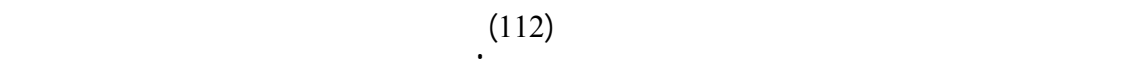

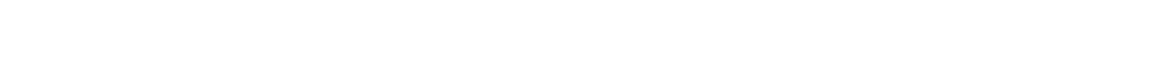

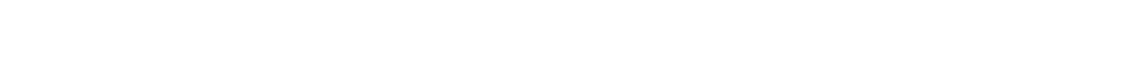

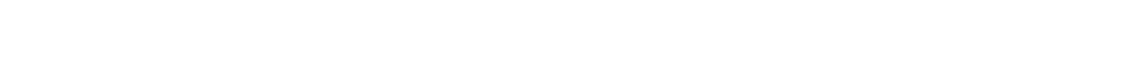

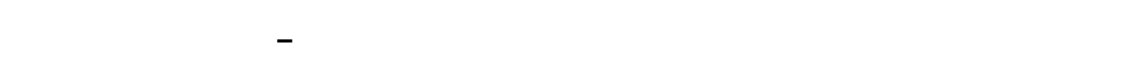

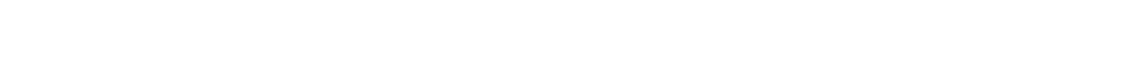

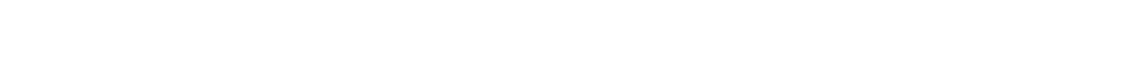

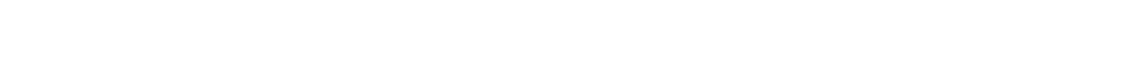

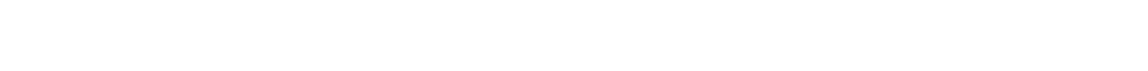

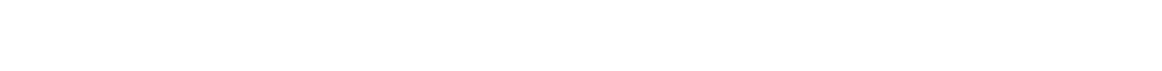
القومي (113. 
في الوقت الذي كانت فيه الولايت المتحة قد صرفت جه ـأ كبي ـرأ

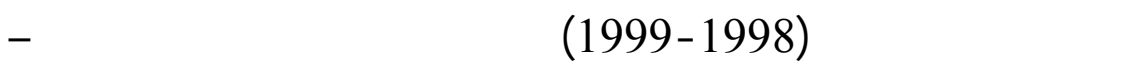

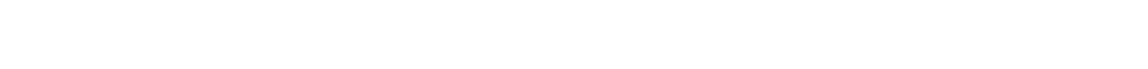

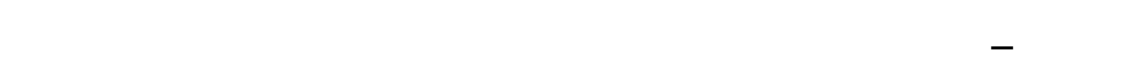

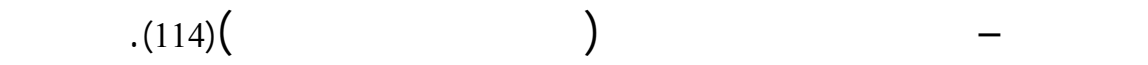

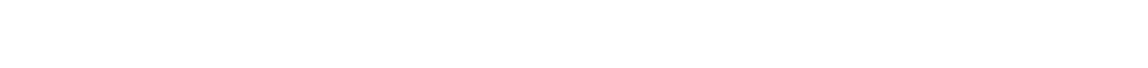

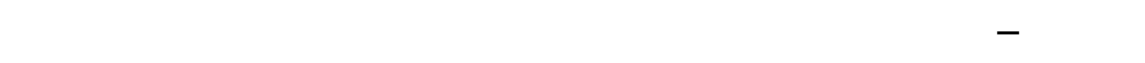
العلاقلت بين البلدين يخدم المصالح الامريكية في مطقة الخلبج والعكس

والواقع ان القارب الايرالي مع اللسعودية لا يمكن فصله عن محاول ـة

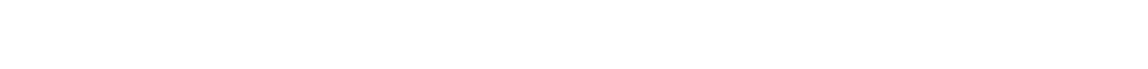

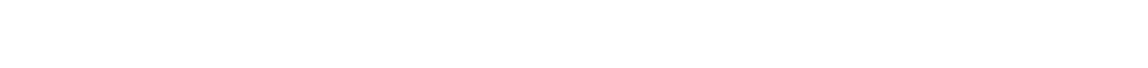

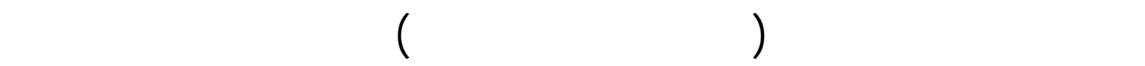

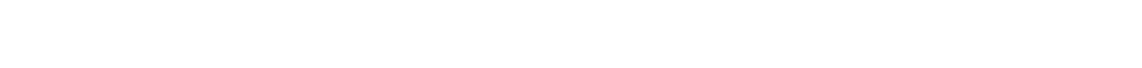

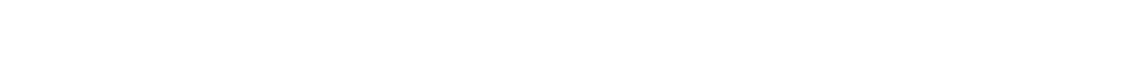

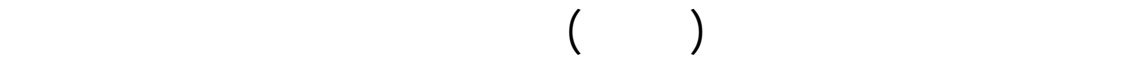

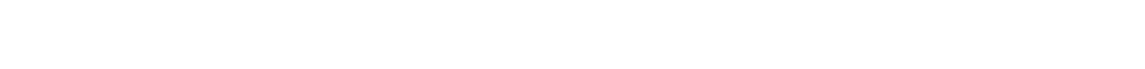

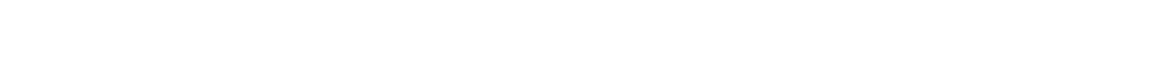

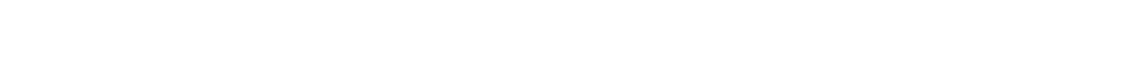

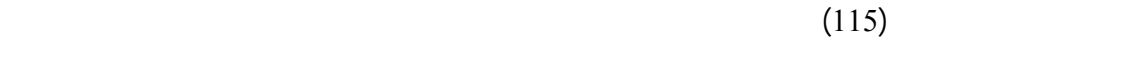

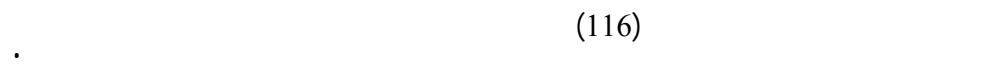




\section{الخاتمــــة}

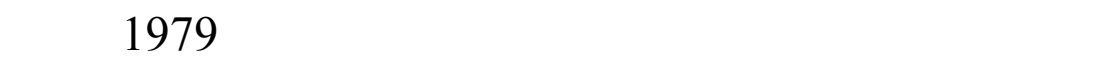

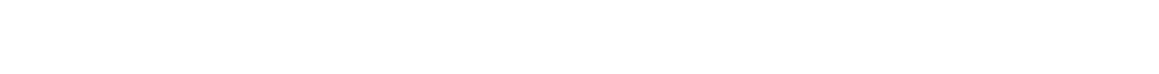

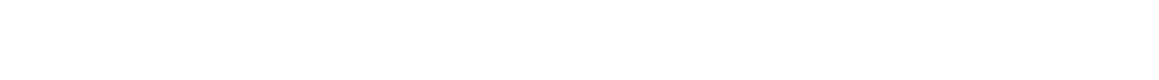

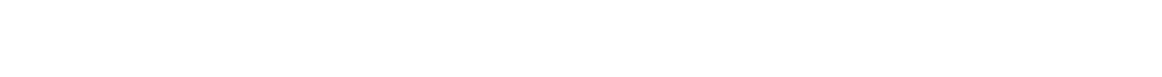

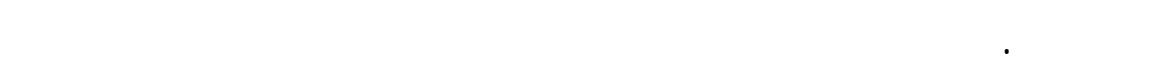
الايرانية على العلاقلت للسيلسية بين البلدين (اليران وللسعودية)، الا النهما

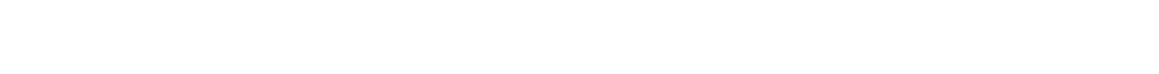

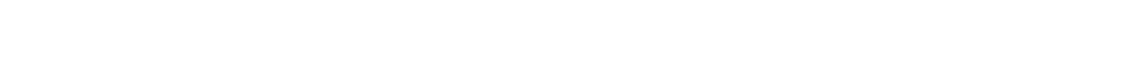

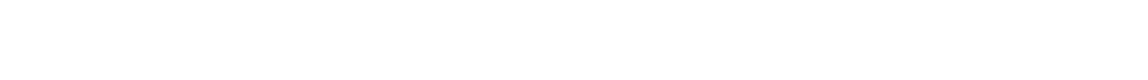

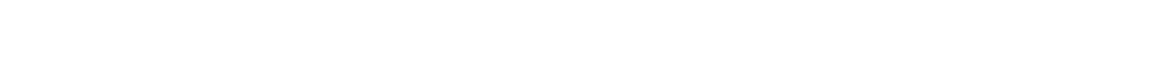

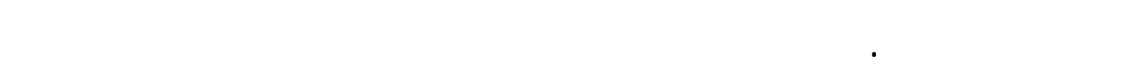

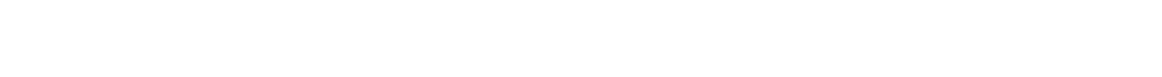

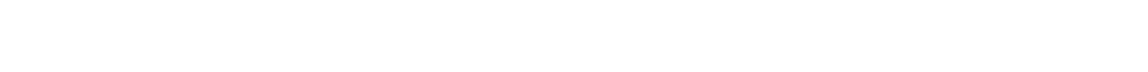
الوضع الموجود في العالم الإلامي.

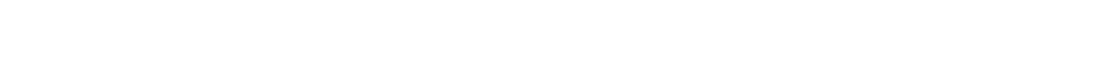

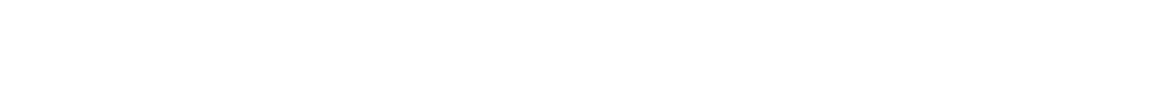

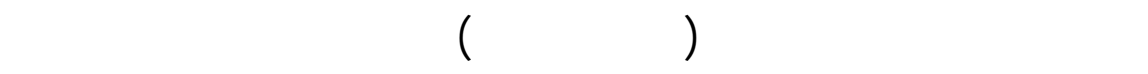

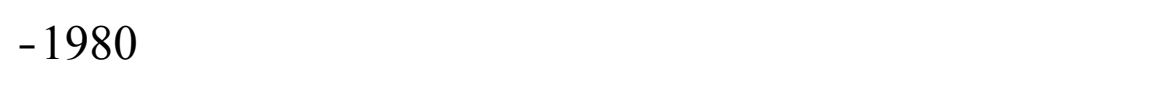

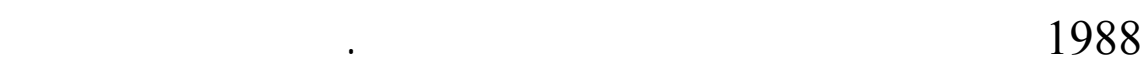

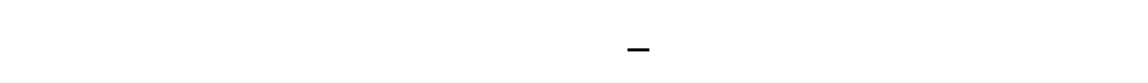




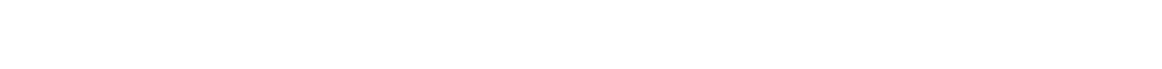

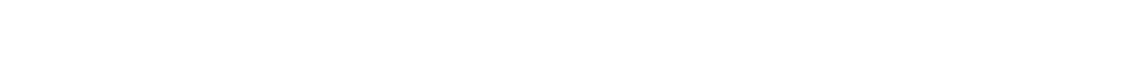

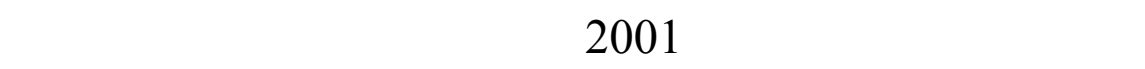

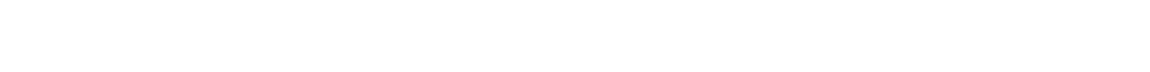
علاقت الدولتين وفي جميع الاصعة .

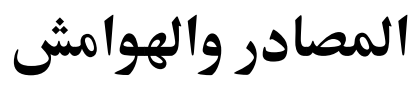

(1)Encyclopedia of Islam.Vol.1,pp.153.

(2) للمزبدمن الفلصل. لتلر:

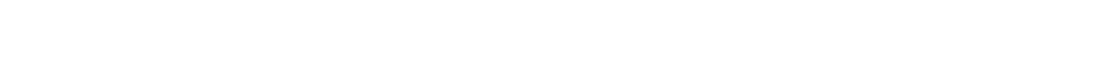
العربية، ترجمة :عبد الجبار

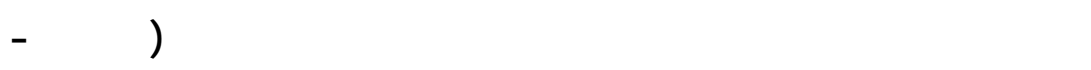
1983)، ص م 239 ومابعنها

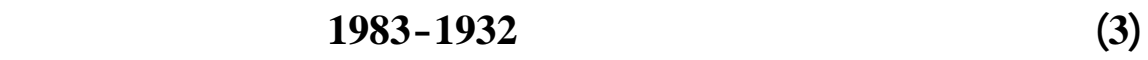

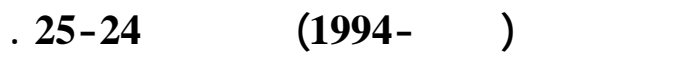

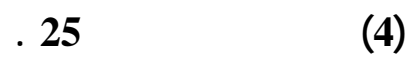

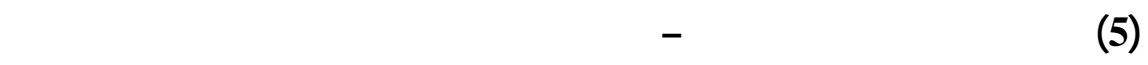
والجزبرة العربة ،العد 23،منشور عل الموقع : المبرية www.alharamain.com/1-3-2004.

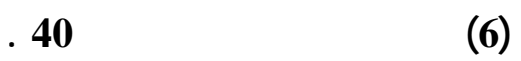

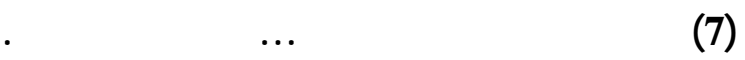

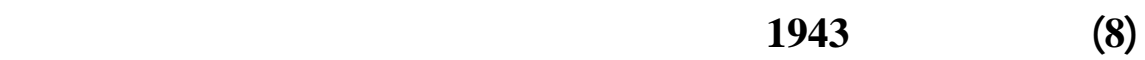

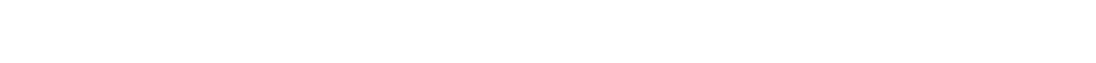

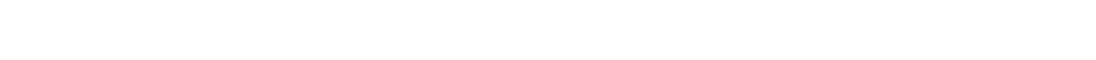




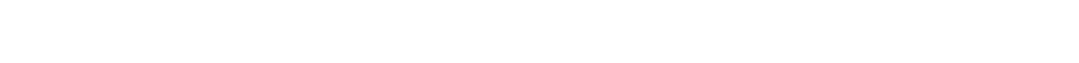

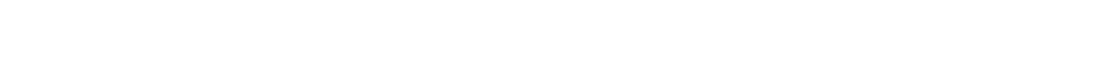

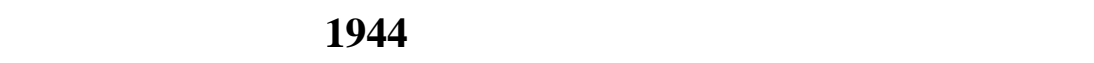

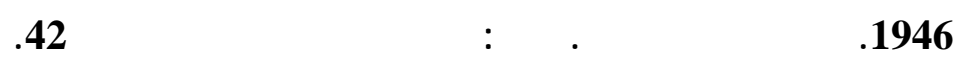

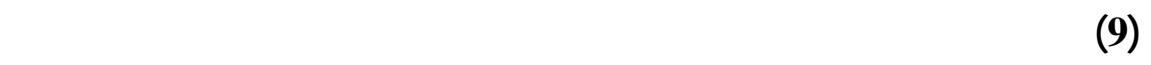

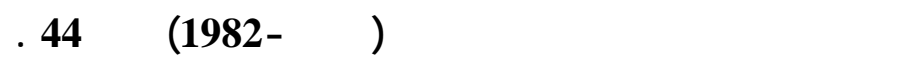

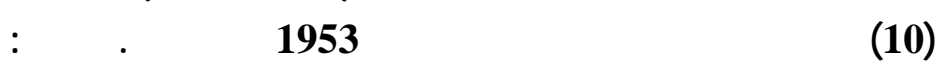

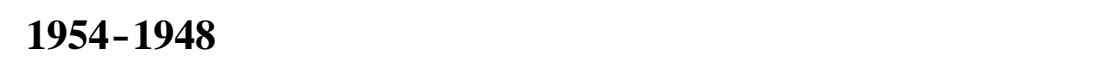

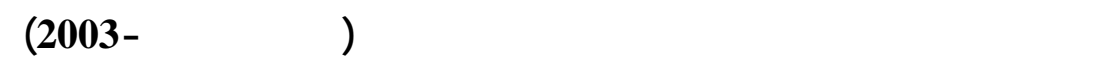

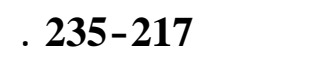

(11) Miron Rezum, The Soviet Union and Iran, (West view press, Boulder, colo, 1987), Table2.1,p79.

(12) Majid Khadduri, Arab Contemporaries: The Role of personalities in politics, (London- 1973), p.88.

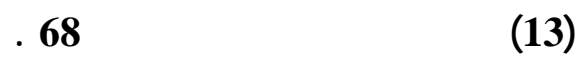

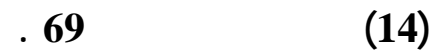

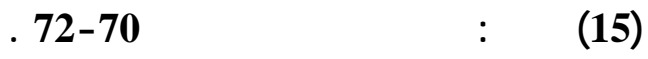

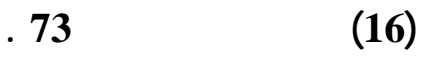

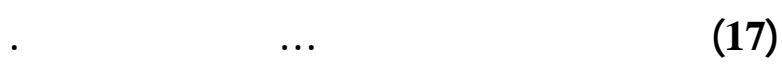

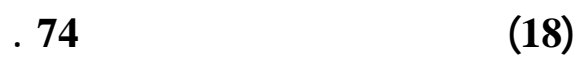

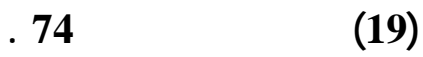

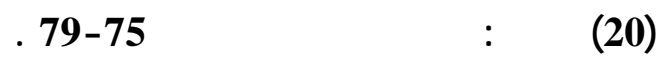

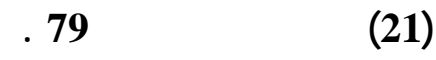

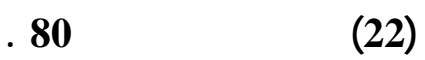

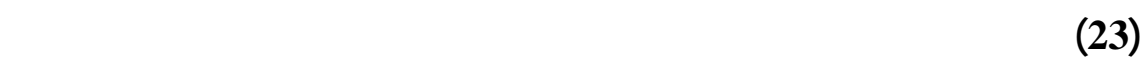

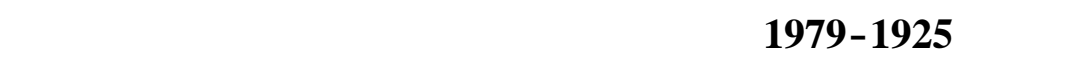


الايرلنية، اعداد:معهد البحوث والمرلسلت، (جامعة الدط العربية بالف اهرة -

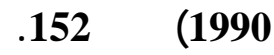

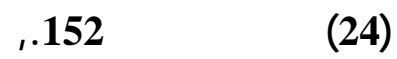

(25) من تاريخ اللكلفالت اللعودية .... المصرر السلبق .

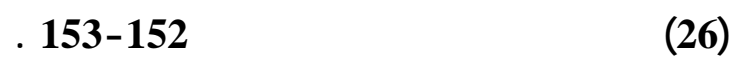

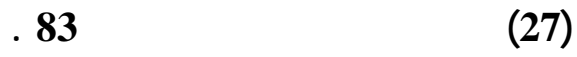

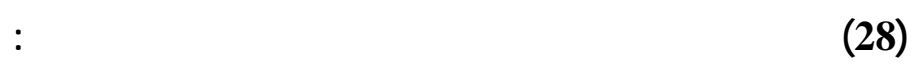
www.makkah.gov.sa/27-9-2000.

(29) صحفيفة للالاعت (الاخبال) الايرلنية في 16 نيسلن 1968 . 190

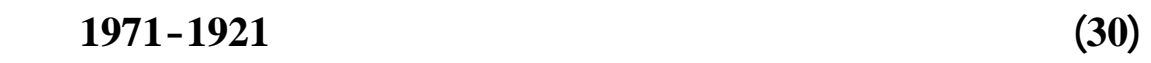

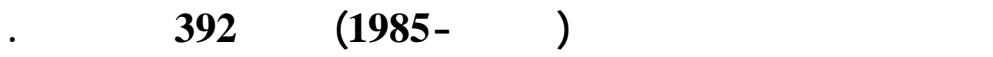

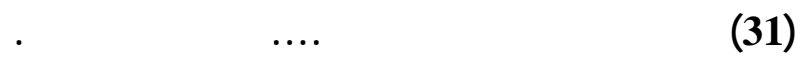

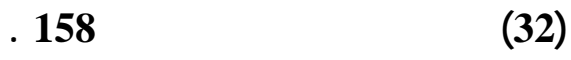

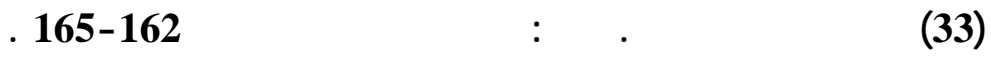

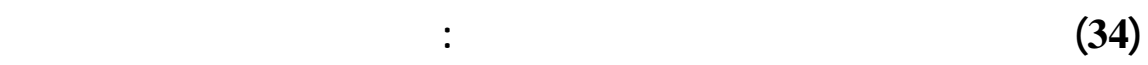

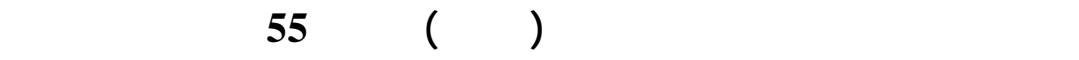

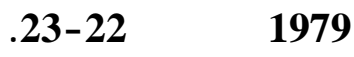

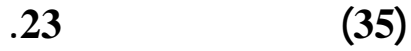

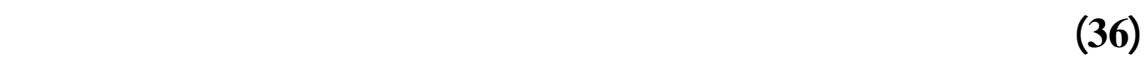

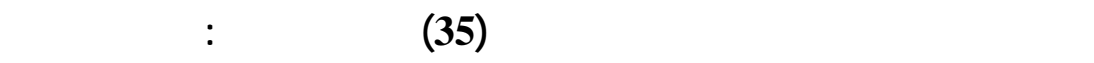

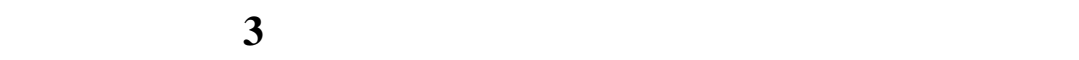

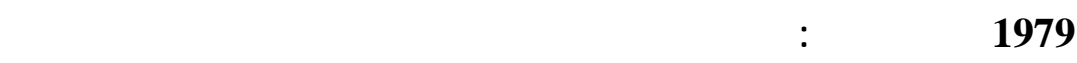

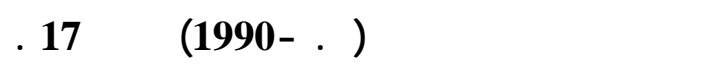

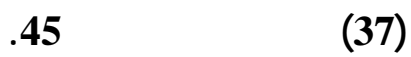

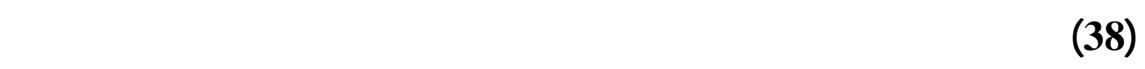

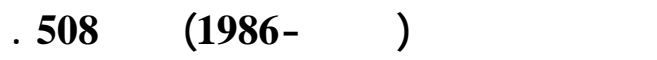

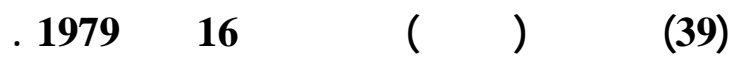

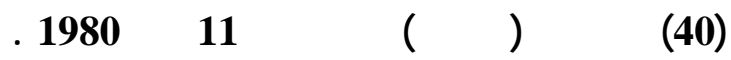


(41) السيلسة (صحفية) الكويتفي 31 تموز 1979 .

(42)اللفير(صحيفة) بيروتف 14 14شبلا 1980 .

(43)New york Time,u.s.a,3-3-1980.

(44) اللفير(صحيفة) بيروت في 25شبلا 1980 .

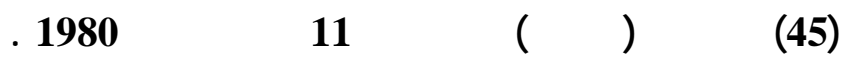

(46) اللفير(صحيفة) بيروت في 25 بشبلا 1980 .

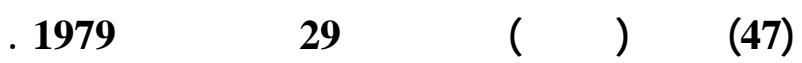

(48) الهف (صحفة) الكويت في 4 كالنهن الالط 1979 . -

(50)قلاً عن التالفزبهن الايرليفي 14 نشرين الثاني 1980 ـ

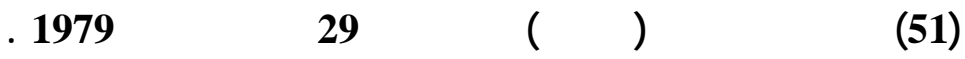

(52)The Economist,British, 30-11-1979.

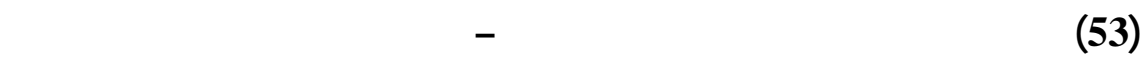

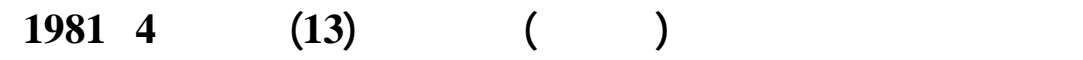

$$
\text { ص }
$$

(54)فلسيليف ، المصدر اللسلق ، ص 509 .

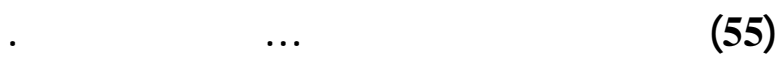

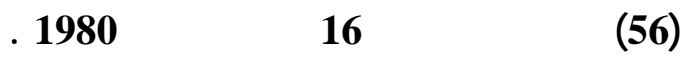

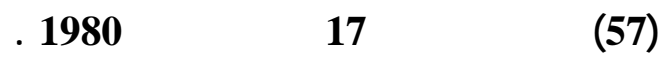

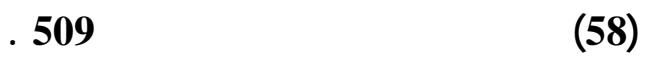

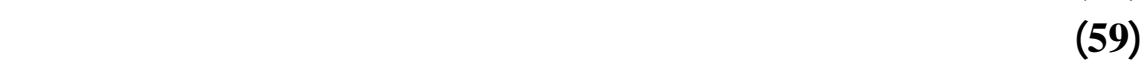

: الموقع

www.alharamain.com/12-4-1999.

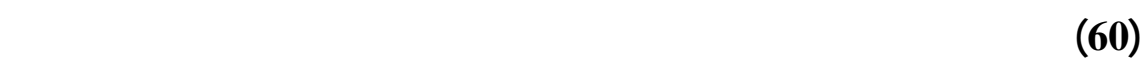

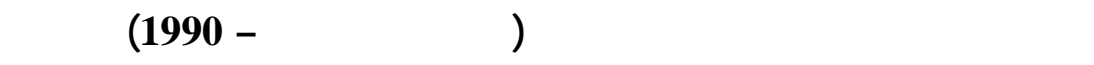

. 


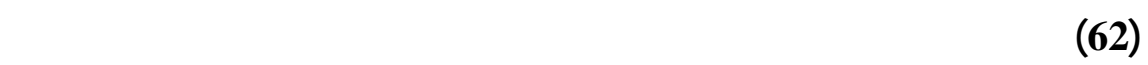

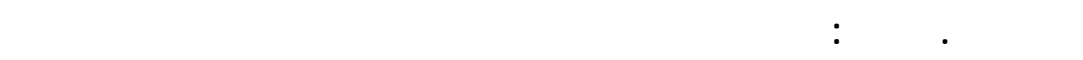

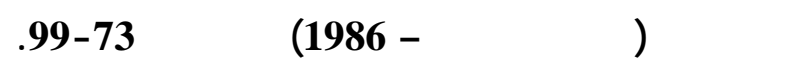
(63) من الورق ندوة الملفلت العربية - الايرلنية في لنهن بناريخ 22 ليار 1999، ص 4.

(64) صحففة صدلي عدالت (صوت العدالة) الايرلنية في 26 آب 2002 .

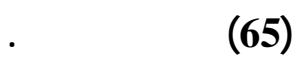

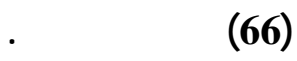

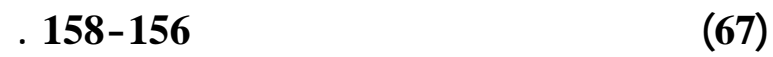

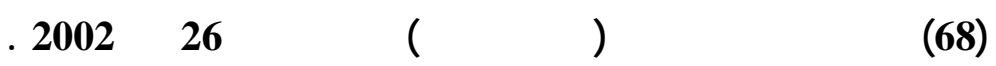

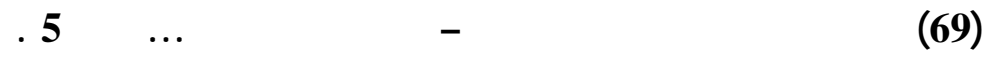

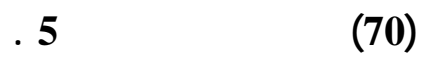

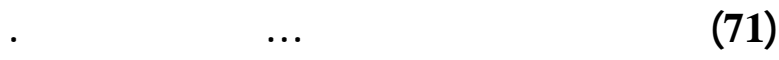

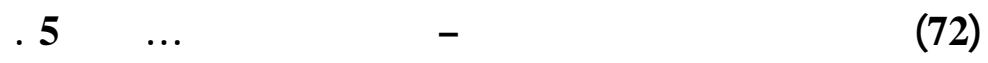

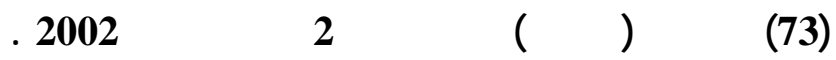

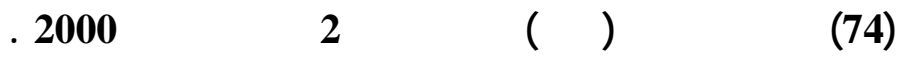

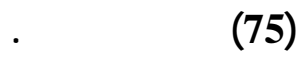

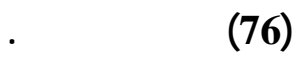

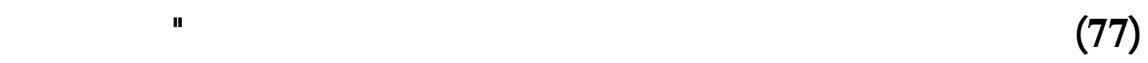

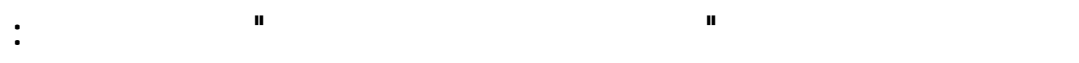

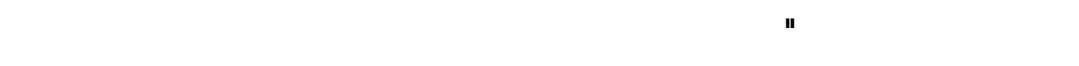

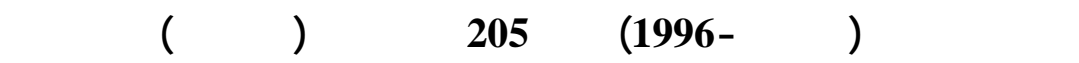

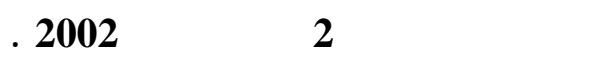

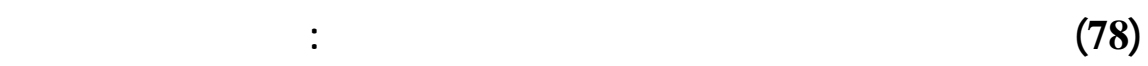

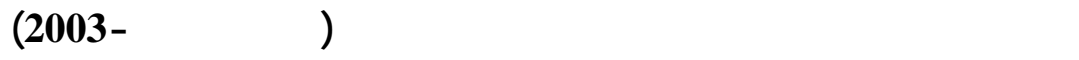

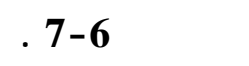

(79) المصر فسه ، وص . 7 (80)

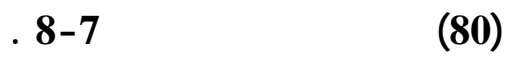


(81) البيلن (صحفة) الامارل العربية المتحةف 2 تشرين لالط 2002 .

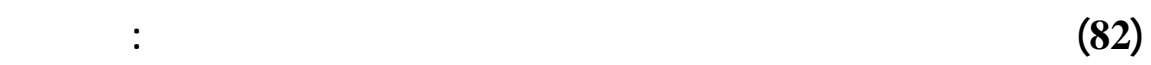

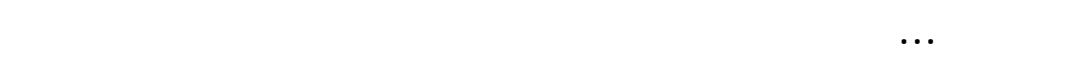

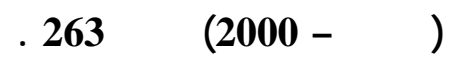

(83) البيلن (صحفية) المارل العربية المتحةف 212 المشبلا 2001 .

. (84) (83) المصرد (85)

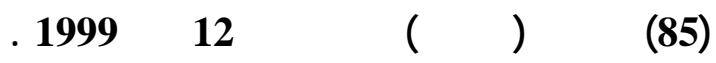

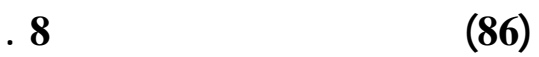
(87) فهدمزيلن خزار الخزار، الاففية الامنية الايرلنية - اللسعوية والنعكلس التها

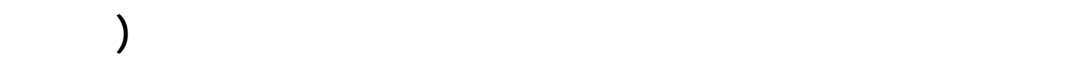

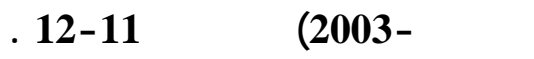

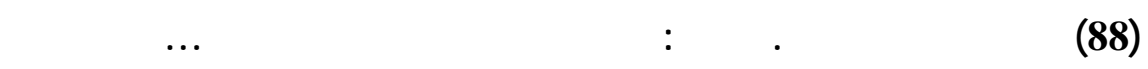

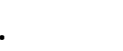

(89) الاهرلم (صحففة) الفاهرةف 12 ليار 1999 ؛ الخزار ، اللكاف لـ الايرلني مة

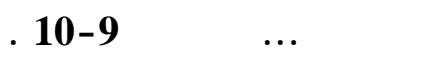

(90) مختارك ليرلنية (دوريقشهرية مصرية) العد 13 ل 10 ، لب 2001 .

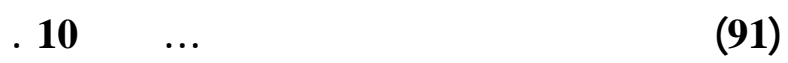

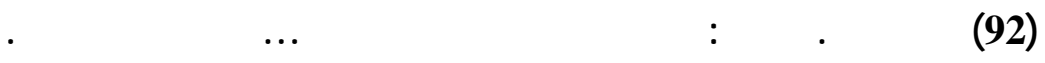

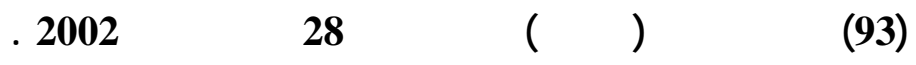

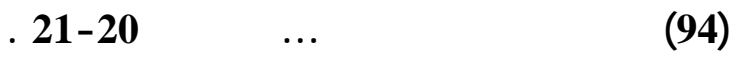
(95) البيلن (صحيفة) الامارل العربية المتحةف 21 المشبلة 2001 .

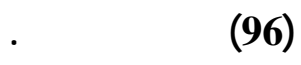

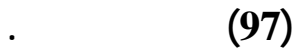

(98) البيل (صحففة) المارل العربية المتحةف 2 تشرين للال 2002 .

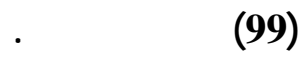

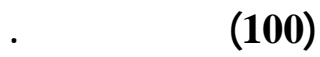
(101) الخبار الخلبج (صحيفة) البحرينف 28كلنهن لالط 2002 . 


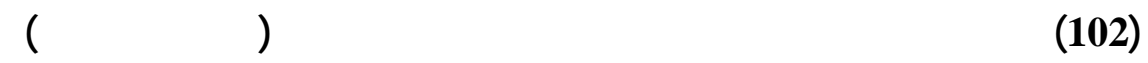

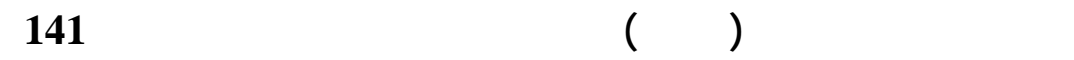

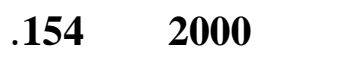
(103) البيل (صحففة) الامارل العربية المتحةف 2 نشرين الال 2002 .

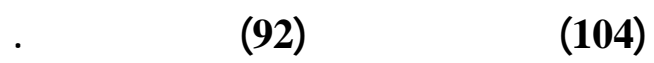

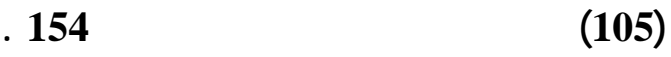

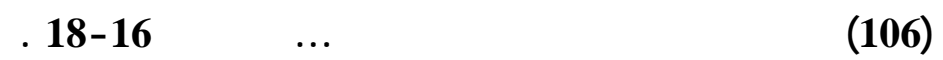

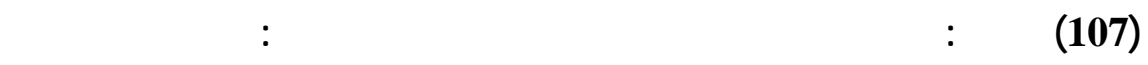

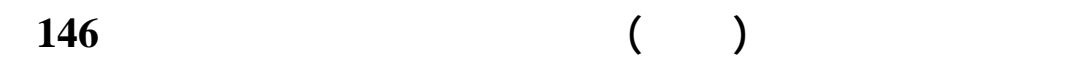

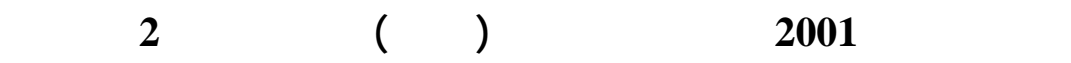

$$
\text { الثالي } 2001 \text {. } 1 \text { (108) }
$$

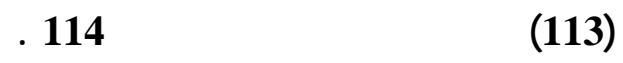

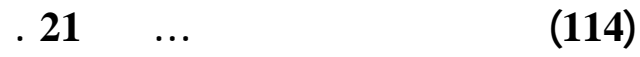

(115) مالح عبد العزبز النجي ، الفارية القارب السعولي - الايرلي :بوفهه ولبع اله ،

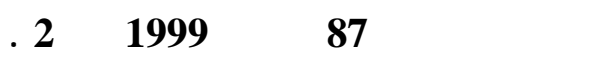
(116) الخزار ، الافلفية المنية ....ص 33 . 37 . 


\title{
Iranian and Sudia Arabia Relations 1979-2001 Political Studies
}

\author{
By: Mr. Mohammad S.A.AL-Kawaz
}

Assistant Lecturer Regional Studies centre University of Mosul

\begin{abstract}
This study tries to present details about the Saudi-Iranian relations on a political level during the period 1979-2001. the rise of the Islamic revolution in Iran in February 1979 was the big point in the relation due to the ideological approach adopted by Iran in its foreign policy. It was called "Revolution Export". This has left a sort of tension in the region especially with the Saudi Arabia continued till the death of Khumani. Then, relations has become different and witnessed a remarked co-operation in all aspects after Mohammed Khatimi has reached the rule in Iran and signed a security agreement in April 2001.
\end{abstract}

